A INFRAESTRUTURA URBANA DE TRANSPORTES E O AQUECIMENTO GLOBAL: UM ESTUDO SOBRE POSSÍVEIS MEDIDAS DE MITIGAÇÃO

Berta Castelar Pinheiro

Dissertação de Mestrado apresentada ao Programa de Pós-graduação em Engenharia de Transportes, COPPE, da Universidade Federal do Rio de Janeiro, como parte dos requisitos necessários à obtenção do título de Mestre em Engenharia de Transportes.

Orientadora: Suzana Kahn Ribeiro

Rio de Janeiro

Março de 2017 
A INFRAESTRUTURA URBANA DE TRANSPORTES E O AQUECIMENTO GLOBAL:

UM ESTUDO SOBRE POSSÍVEIS MEDIDAS DE MITIGAÇÃO

\author{
Berta Castelar Pinheiro
}

DISSERTAÇÃO SUBMETIDA AO CORPO DOCENTE DO INSTITUTO ALBERTO LUIZ COIMBRA DE PÓS-GRADUAÇÃO E PESQUISA DE ENGENHARIA (COPPE) DA UNIVERSIDADE FEDERAL DO RIO DE JANEIRO COMO PARTE DOS REQUISITOS NECESSÁRIOS PARA A OBTENÇÃO DO GRAU DE MESTRE EM CIÊNCIAS EM ENGENHARIA DE TRANPORTES.

Examinada por:

Prof ${ }^{a}$. Suzana Kahn Ribeiro, D.Sc.

Prof. Ronaldo Balassiano, Ph.D.

Prof. José Antonio Marengo Orsini, Ph.D.

RIO DE JANEIRO, RJ - BRASIL

MARÇO DE 2017 
Pinheiro, Berta Castelar

A infraestrutura urbana de transportes e o Aquecimento

Global: Um estudo sobre possíveis medidas de mitigação/

Berta Castelar Pinheiro - Rio de Janeiro UFRJ/COPPE, 2017.

X, 94 p.: il.; $29,7 \mathrm{~cm}$.

Orientadora: Suzana Kahn Ribeiro

Dissertação (mestrado) - UFRJ/ COPPE/ Programa de Engenharia de Transportes, 2017.

Referências Bibliográficas: p. 87-94.

1. Aquecimento Global. 2. Infraestrutura urbana de transportes. 3. Políticas de mitigação. I. Ribeiro, Suzana

Kahn. II. Universidade Federal do Rio de Janeiro, COPPE,

Programa de Engenharia de Transportes. III. Título. 


\section{Agradecimentos}

Além de todo conhecimento científico adquirido, o que levarei adiante ao fim desta etapa é que nada se constrói sozinho. Este trabalho foi construído por diversas pessoas, as quais aqui agradeço de forma simbólica.

Agradeço primeiramente, a peça fundamental não só desta dissertação, mas de minha vida profissional, minha orientadora Suzana Kahn. Meu muito obrigada por todas as oportunidades e portas que você me abriu. Espero que esta nossa pesquisa tenha acrescentado a você ao menos uma parte do que acrescentou em mim.

Agradeço ao meu professor e membro desta banca Ronaldo Balassiano, a quem, desde sua primeira aula admiro por sua simpatia e dedicação com os alunos. Por meio de suas histórias, aprendi as mais distintas abordagens sobre sistema de transportes e cidades. Sou grata também ao grande pesquisador José Marengo pela disponibilidade de participar desta banca.

Ao amor e dedicação dos meus pais, que de formas tão distintas me deram a força necessária para seguir adiante. Minha mãe e amiga, pela paciência e companhia diária. Meu pai, quem tanto me apoiou e me aconselhou nestes dois anos. Obrigada pelas revisões de textos, pelas conversas inspiradoras e principalmente por sempre acreditar em mim. Sou imensamente grata a vocês dois.

Ao meu irmão, quem suportou as minhas alterações de humor, reconheço que as vezes constantes. Obrigada por estar sempre ao meu lado. Ao meu namorado, quem conseguiu, apesar da distância nunca estar ausente e me apoiar com todo o conforto nos momentos de angústia. Obrigada por tudo. Vocês dois tornam minha vida muito mais feliz.

Nestes dois anos fiz amigos que hoje levo comigo e sem os quais não teria chegado até aqui. Meu querido amigo Luiz Saldanha, para mim o melhor turismólogo engenheiro de transportes. Além de amigo e muitas vezes professor nas madrugadas de trabalho, um Dj responsável por alegrar o meu caminho. Agradeço também a Elizabeth Lima, quem nestes anos de trabalho me ensinou muito, inclusive sobre mim mesma.

A minha família, e não só aquela de sangue. Agradeço especialmente, meus tios Marcílio e Cristina. Amor e Força. Gostaria que vocês estivessem aqui. Agradeço a minha grande amiga Fernanda Alice, que me deu força e paciência para conquistar esse objetivo. Agradeço ao Insituto de Urbanismo Pereira Passos (IPP) pelas informações disponibilizadas. Em especial, agradeço ao Felipe Mandarino, pelo carinho e tempo dedicado as consultorias de ArcGIS. 
Para minha amiga Julia Gabriela, transformo esse agradecimento em um pedido de desculpas pela ausência neste período. Agradeço pela companhia do meu amigo André, que me deu toda energia e animação necessária para seguir na reta final.

Não posso deixar de agradecer o que para mim é sinônimo de alegria, a Capoeira. Agradeço em especial ao Professor Grande e seus alunos, que tanto me ajudaram a desestresar e voltar para casa sempre mais leve.

Para concluirmos uma etapa que exige tanta dedicação, muitas vezes fazemos escolhas que nos trazem os mais diversos medos e inseguranças. Terminar esta etapa e olhar para trás me enche de felicidade por tudo que conquistamos.

A todos vocês, meu muito obrigada. 
Resumo da Dissertação apresentada à COPPE/UFRJ como parte dos requisitos necessários para a obtenção do grau de Mestre em Ciências (M.Sc.)

\title{
A INFRAESTRUTURA URBANA DE TRANSPORTES E O AQUECIMENTO GLOBAL: UM ESTUDO SOBRE POSSÍVEIS MEDIDAS DE MITIGAÇÃO
}

\author{
Berta Castelar Pinheiro \\ Março/2017
}

Orientadora: Suzana Kahn Ribeiro

Programa: Engenharia de Transportes

O aquecimento global é uma realidade e a tendência de crescimento das cidades, grandes focos de impactos ao meio ambiente, alertam para a urgência da implantação de medidas de mitigação.

O setor de transportes é responsável por uma parcela significativa da contribuição antrópica ao aumento de temperatura da superfície terrestre. Ainda que a emissão de gases de efeito estufa seja a principal fonte de impacto do setor as mudanças climáticas, esta não é a única. Desta forma, este trabalho apresenta o impacto do setor de transporte rodoviário no aquecimento global a partir da sua infraestrutura urbana. Este impacto decorre da utilização de materiais urbanos de superfícies escuras, como concreto e asfalto, que possuem uma baixa capacidade de refletir a radiação solar e por isso, retém mais calor.

Este trabalho apresenta um estudo de caso sobre o impacto da infraestrutura urbana de transportes da cidade do Rio de Janeiro no aquecimento global. Paralelamente à análise dos impactos de sua infraestrutura, o estudo apresenta possíveis medidas de mitigação como técnicas de geoengenharia e medidas de planejamento urbano integrado ao sistema de transportes. Por fim, ao discorrer sobre as diferentes fontes de impacto do setor de transportes assim como suas medidas de mitigação, o estudo reconhece a importância significativa deste setor às mudanças climáticas. 
Abstract of Dissertation presented to COPPE/UFRJ as a partial fulfillment of the requirements for the degree of Master of Science (M.Sc.)

\title{
URBAN TRANSPORT INFRASTRUCTURE AND GLOBAL WARMING: A STUDY ABOUT MITIGATION POLICIES
}

\author{
Berta Castelar Pinheiro \\ $\operatorname{March} / 2017$
}

\section{Advisor: Suzana Kah Ribeiro}

Department: Transport Engineering

Global warming is a reality and the trend of urban growth, major centers of environmental impacts and the vulnerability of these areas to climate change highlights the urgency for mitigation measures.

The transport sector has a great impact on global warming. Although this impact is mainly associated with high greenhouse gas emissions, the transport sector also influences the environment through its infrastructure. This impact derives from the use of dark surfaces materials, such as concrete and asphalt, which have a low capacity to reflect solar radiation and, therefore, retain more heat. As the road transport sector is essential to cities development, it its expected that transport infrasctuture will also increase with the growth of urban centers. Therefore, this Master Thesis analyses the city impact on global warming through the road transport infrastructure.

To do so, the study presents a case study on the impact of the Rio de Janeiro urban transport infrastructure on global warming. Parallel to the analysis of the impacts of transport infrastructure on climate change, this study analyses mitigation measures, such as geoengineering and urban planning. Finally, through the discussion of the different sources of impact of the transport sector as well as its mitigation measures, the study recognizes the significant importance of this sector to climate change. 


\section{SUMÁRIO}

1 CAPÍTULO 1: CONSIDERAÇÕES INICIAIS ......................................................................................

1.1 Apresentação do tema e objeto de estudo.................................................................................

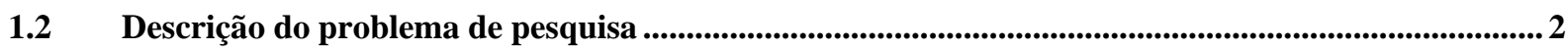

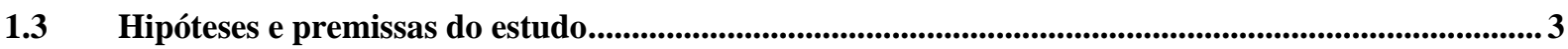

1.4 Objetivos: Geral e Específico ………………........................................................................................ 3

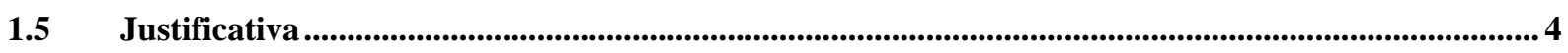

1.6 Delimitação da pesquisa.............................................................................................................. 4

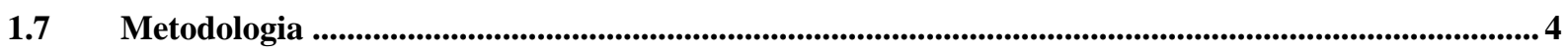

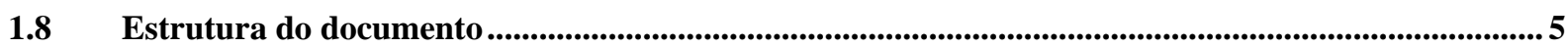

2 CAPÍTULO 2: SISTEMA CLIMÁTICO, AQUECIMENTO GLOBAL E FORÇANTES

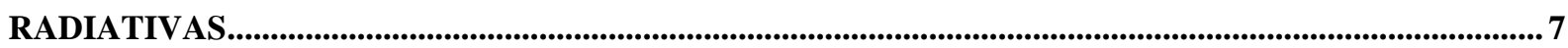

2.1 Panorama Inicial do aquecimento global e mudanças climáticas ............................................................ 7

2.2 Sistema climático e aquecimento global .......................................................................................... 11

2.3 Forçantes radiativas do sistema climático e o aquecimento global .........................................................14

2.4 Evolução da preocupação histórica com o tema: conhecimento científico e negociações

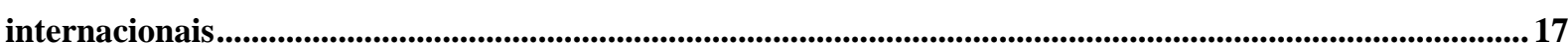

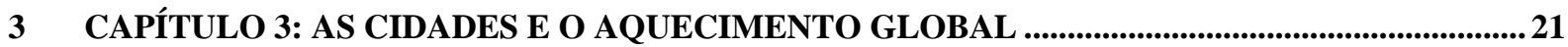

3.1 Mudança Climática e Urbanização.............................................................................................................. 21

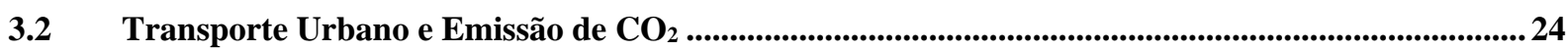

3.2.1 Emissões de GEE no transporte das cidades brasileiras................................................................. 28

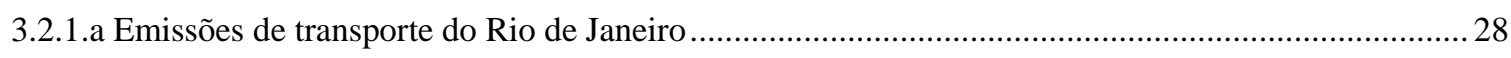

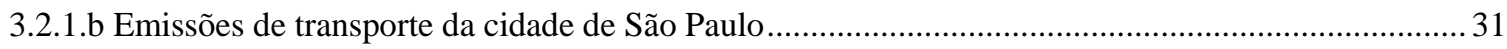

3.2.1.c Emissões de Transporte em Belo Horizonte ………….................................................................... 33

3.2.1. d Emissões de Transporte em Recife .......................................................................................... 35

3.2.1.e Considerações finais acerca dos inventários de emissões municipais.................................................. 36

3.3 Infraestrutura urbana de transportes e aquecimento global......................................................................... 38

3.3.1 Infraestrutura urbana de transportes e o uso do espaço viário........................................................4 44

3.3.2 Políticas de mitigação ao impacto da infraestrutura urbana de transportes no aquecimento global..... 47

4 CAPÍTULO 4: ESTUDO DE CASO DO IMPACTO DA INFRAESTRUTURA URBANA DE TRANSPORTES NO RIO DE JANEIRO E SUA CONTRIBUIÇÃO PARA O AQUECIMENTO

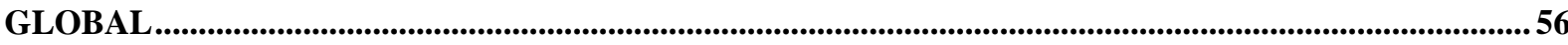

4.1 Contextualização sobre a área de estudo..........................................................................................5 56

4.2 A infraestrutura de transporte do Rio de Janeiro e sua contribuição para o Aquecimento Global61

4.2.1 Área total da infraestrutura urbana de transportes no Rio de Janeiro (Etapa 1) ...............................62 62

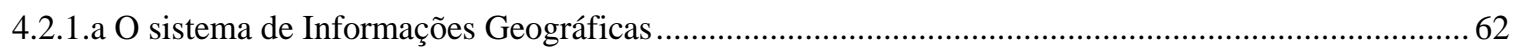

4.2.1.b O Sistema de Informação Geográfica e a identificação das áreas de via na cidade do Rio de Janeiro

4.2.1.c O cálculo da área total de vias na cidade do Rio de Janeiro..................................................... 71

4.2.2 Radiação solar absorvida pelas vias no Rio de Janeiro (Etapa 2) .............................................. 73 


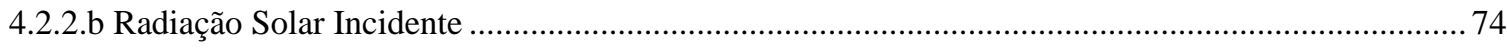

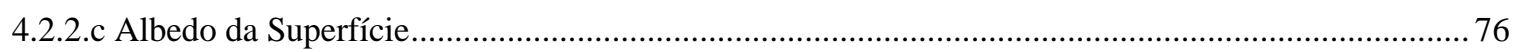

4.2.3 Radiação solar total absorvida pelas vias no Rio de Janeiro (Etapa 3) ..........................................78

4.3 Considerações finais sobre o impacto da infraestrutura urbana de transportes no Rio de Janeiro e sua contribuição para o Aquecimento Global.........................................................................................................79

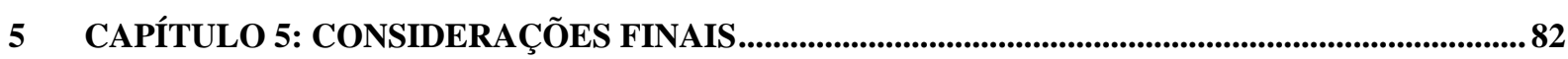

\section{ÍNDICE DE FIGURAS}

Figura 1: Emissões Antrópicas de Gases de Efeito Estufa (1970-2010) ...................................................... 10

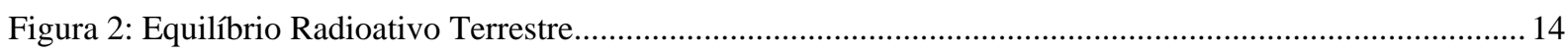

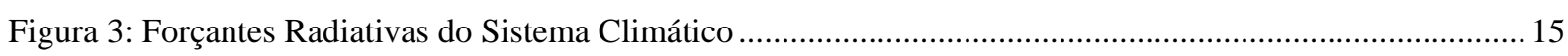

Figura 4: Consumo final de energia dos combustíveis por subsetor de transportes (2009)..............................26

Figura 5: Emissões de GEE do setor de Energia por subsetor no município do RJ (Gg CO2eq)........................29

Figura 6: Emissões das Unidades Móveis - Detalhamento por modal ............................................................ 34

Figura 7: Matriz energética do sistema de transportes em Belo Horizonte, 2008 a 2013 ................................. 35

Figura 8: Total de emissões (tCO2eq) em Recife por tipo de combustível ......................................................... 36

Figura 9: Área destinada a vias em cidades da Europa, América do Norte e Oceania ......................................42

Figura 10: Área destinada a vias em cidades da África, Ásia, América Latina e Caribe.................................... 43

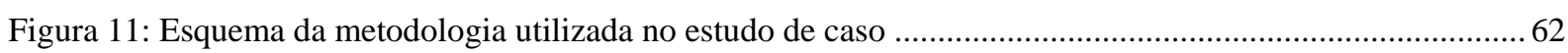

Figura 12: Identificação das áreas de vias na cidade do Rio de Janeiro - Enfoque abrangente ..........................67

Figura 13: Identificação das áreas de vias na cidade do Rio de Janeiro - Enfoque localizado ............................67

Figura 14: Resultado 1 da Ferramenta Erase - Áreas de quadras do município do Rio de Janeiro......................6 68

Figura 15: Resultado da Ferramenta Merge - Áreas de quadras do município do Rio de Janeiro anos de

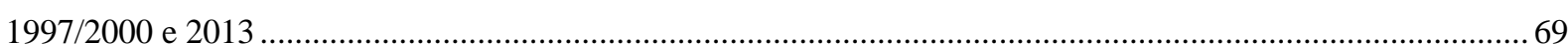

Figura 16: Resultado 2 da Ferramenta Erase - Áreas de vias do município do Rio de Janeiro...........................70

Figura 17: Comparação entre áreas não urbanizadas e as áreas de vias no município do Rio de Janeiro .............72

Figura 18: Mapas com as médias anual e sazonal do total diário de irradiação solar global no Brasil .................75

\section{ÍNDICE DE TABELAS}

Tabela 1: Principais Gases de Efeito Estufa e respectivos Potenciais de Aquecimento Global (GWP)............... 8

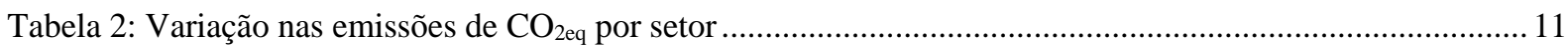

Tabela 3: Elementos do Sistema Climático e suas características ......................................................................... 13

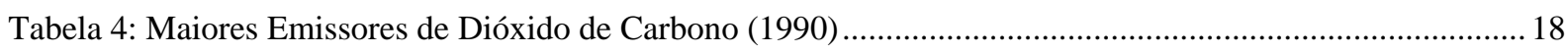

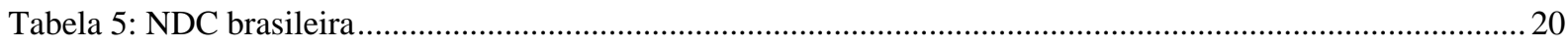

Tabela 6: Porcentagem de emissões urbanas por região geográfica (2000) ......................................................22

Tabela 7: Emissões em CO2eq nos Setores Socioeconômicos - Energéticos do Setor de Transportes .................30

Tabela 8: Emissões totais de GEE - setor de energia e transportes do Município do Rio de Janeiro (2005) ........ 31 
Tabela 9: Emissões totais de GEE da categoria de transporte em CO2eq nos anos de 2005 a 2009 - Município de SP

Tabela 10: Emissões do Município de SP contabilizadas em transporte aéreo e rodoviário nos anos de 2005 a 2009 - Município de SP

Tabela 11: Participação do setor de transporte nas emissões municipais de gases de efeito do setor de energia.. 37

Tabela 12: Participação do modo rodoviário nas nas emissões municipais de gases de efeito estufa do setor de transportes .37

Tabela 13: Ocupação da área urbana em regiões metropolitanas - EUA............................................................ 39

Tabela 14: Estudos sobre impacto da infraestrutura urbana e aquecimento global ...................................... 40

Tabela 15: Espaço viário usado pelas pessoas em ônibus e em carros, várias cidades brasileiras (1998)............. 46

Tabela 16: Espaço ocupado na via pelos modos de transporte no espaço urbano ........................................... 46

Tabela 17: Estudos sobre políticas de mitigação ao impacto da infraestrutura urbana no aquecimento global .... 49

Tabela 18: Incentivos e medidas do gerenciamento da mobilidade..............................................................51

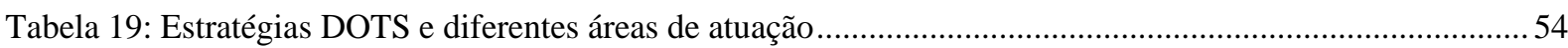

Tabela 20: Riscos e Consequências Identificadas no Programa Rio Resiliente ...............................................59

Tabela 21: Grupos do Sistema de Informações Geográficas e suas áreas de aplicação......................................63

Tabela 22: Funções do SIG-T e suas ações de planejamento e gestão de transportes .......................................65

Tabela 23: Síntese dos procedimentos usados para a identificação das áreas de via no Rio de Janeiro ............... 71

Tabela 24: Síntese dos resultados do estudo de caso sobre o município do RJ ..............................................72

Tabela 25: Valores médios de radiação solar no Estado do Rio de Janeiro...................................................... 76

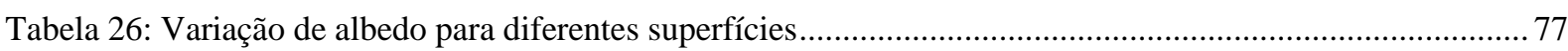

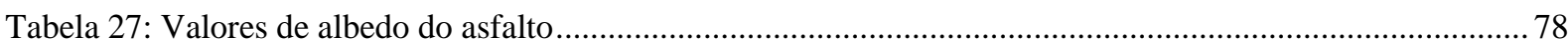

Tabela 28: Elementos para o cálculo de absorção das vias urbanas na cidade do Rio de Janeiro ........................78

\section{ÍNDICE DE GRÁFICOS}

Gráfico 1: Estrutura modal transporte de carga (Bilhões de t.km) ...............................................................2 27

Gráfico 2: Estrutura Modal - Transporte de Passageiros (bilhões de passageiros $/ \mathrm{km}$ )...................................28

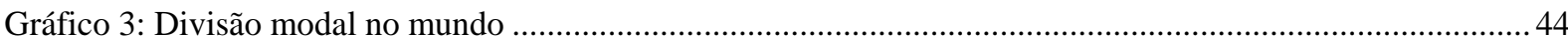

Gráfico 4: Uso do espaço público para transporte de passageiros por modo de transporte ............................... 45

\section{ÍNDICE DE EQUAÇÕES}

Equação 1: Equação do Albedo e Fatores Envolvidos ............................................................................... 73

Equação 2: Radiação absorvida por uma determinada superfície ............................................................ 73

Equação 3: Equação da absorção de radiação solar pela superfície asfáltica no município do Rio de Janeiro ..... 79 Equação 4: Equação da absorção de radiação solar total pela superfície asfáltica no município do Rio de Janeiro 


\section{Capítulo 1: Considerações Iniciais}

\subsection{Apresentação do tema e objeto de estudo}

$\mathrm{O}$ aquecimento do sistema climático é atualmente um fato inequívoco, como aponta o Painel Intergovernamental de Mudanças Climáticas (IPCC, sigla em inglês para Painel Intergovernamental sobre Mudanças Climáticas). O IPCC reconhece também que a participação antrópica neste fenômeno já não é mais motivo de dúvida e que esta ocorre principalmente devido as emissões de gases de efeito estufa (GEE). Destacam-se dentre estes gases, o Dióxido de Carbono $\left(\mathrm{CO}_{2}\right)$, oriundo da queima de combustíveis fósseis, o Metano $\left(\mathrm{CH}_{4}\right)$ e o Óxido Nitroso $\left(\mathrm{N}_{2} \mathrm{O}\right)$, sobretudo provenientes das atividades agropecuárias (Garcias e Silva, 2011).

A literatura científica sobre o aquecimento global reconhece que a participação antrópica nas emissões de GEE está essencialmente ligada às cidades ${ }^{1}$. Isto porque as cidades reúnem a maior parte da população mundial e a maioria de suas atividades, concentrando uma parcela considerável das emissões globais de GEE (Santos, 2014). De acordo com Marcotullio et al (2013), dos 34.8 bilhões de $\mathrm{tCO}_{2 \text { eq }}$ emitidos no ano de 2000, entre 12.8 e 16.9 bilhões de $\mathrm{tCO}_{2 \text { eq }}$ foram emitidos em áreas urbanas com mais de 50.000 habitantes. Na mesma linha, a IEA (2008) estima as áreas urbanas são responsáveis por 71\% das emissões de carbono globais relacionadas a energia.

Dentre as atividades urbanas que mais contribuem para as emissões antrópicas de gases de efeito estufa, está o setor de transportes. Segundo o último relatório do IPCC (IPCC, 2014c), o setor de transporte é responsável por $27 \%$ da utilização final de energia global, das quais em torno de $70 \%$ são provenientes de combustíveis fósseis não renováveis, com alto nível de emissão de GEE. O relatório apontou também, que em 2010 o setor de transportes foi responsável pela emissão de $6,7 \mathrm{GtCO}_{2}$, dos quais $40 \%$ foi utilizado apenas no transporte urbano.

Os impactos do setor de transportes oriundos do elevado consumo de energia são atualmente amplamente discutidos pela literatura científica. No entanto, este trabalho mostra uma percepção diferenciada da contribuição do setor de transportes no aquecimento global: o impacto de sua infraestrutura urbana. A infraestrutura urbana de transportes é caracterizada essencialmente pelo uso de materiais de superfícies escuras, como o concreto e o asfalto. $\mathrm{O}$ uso

\footnotetext{
${ }^{1}$ Entende-se neste trabalho, cidade no sentido lato de áreas urbanas, incorporando regiões metropolitanas. No caso das referências ao IPCC, considerou-se "human settlements" como cidades. Segundo tradução literal do IPPC "human settlements" são lugares e áreas ocupados por colonos.
} 
destas superfícies retém calor em forma de radiação solar, aquecendo a superfície terrestre e contribuindo para o aquecimento global.

A porção de radiação refletida por uma superfície é determinada pelo seu albedo. $O$ albedo de uma superfície é caracterizado pela razão entre a radiação incidente e a radiação refletida. Portanto, quanto menor o albedo da superfície mais radiação ela retém e maior é o calor transmitido para o ambiente ao redor (Gartland, 2010). Desta forma, este estudo mostra que o uso de materiais escuros como concreto e asfalto nas vias e estacionamentos das cidades aumenta a retenção da radiação solar na superfície terrestre e consequentemente o calor na atmosfera terrestre.

Apesar desta retenção de calor atualmente não ser caracterizada como de extrema importância, o crescente aumento das áreas urbanas traz a tal fato um sentido de alerta. Segundo IPCC (2014a), a estimativa é que a população urbana aumente em 1 milhão de habitantes a cada 13 anos. Com esse crescimento, é de se esperar que tanto as emissões de GEE quanto o impacto proveniente da infraestrutura urbana se tornem cada vez mais significativos. No tocante as emissões de GEE, pode-se dizer que os estudos e modelos estudados atualmente são capazes de direcionar possíveis medidas de mitigação, no entanto, não se pode afirmar o mesmo sobre os impactos da infraestrutura urbana.

Desta forma, este estudo se concentra em reconhecer o papel da infraestrutura urbana de transportes no aquecimento global, apresentando possíveis medidas de mitigação. Para tornar a relação entre a infraestrutura urbana de transportes e o aquecimento global mais compreensível, esta pesquisa analisa o impacto desta infraestrutura no aquecimento global a partir de um estudo de caso da cidade do Rio de Janeiro. A escolha desta cidade foi baseada no fato desta ser a principal cidade de um estado em crescimento e a segunda maior metrópole brasileira.

\subsection{Descrição do problema de pesquisa}

O aquecimento global é um fenômeno caracterizado pela maior retenção da radiação solar na superfície terrestre, que gera um aumento da temperatura atmosférica. O setor de transportes, devido ao seu alto consumo de energia e emissões de $\mathrm{CO}_{2}$ é visto como uma das principais fontes de participação antrópica a tal fenômeno. Todavia, o impacto desse setor no aquecimento global vai além das emissões de gases de efeito estufa. A construção da infraestrutura urbana necessária para o seu desenvolvimento e atividade alteram a capacidade da terra de refletir radiação e também provocam impactos diretos no balanço de energia terrestre. A forma de medir o potencial de refletir e absorver radiação das superfícies é o albedo. 
O albedo é a razão entre a radiação incidente e a radiação refletida. Em linhas gerais, tem-se que superfícies escuras, como aquelas usadas na infraestrutura urbana de transportes, possuem albedos mais baixos, e por isso, retém a maior parte da radiação recebida.

A partir de tal situação, o que esta pesquisa investiga é: Como a infraestrutura urbana de transportes influencia o aquecimento global?

\subsection{Hipóteses e premissas do estudo}

A elaboração deste trabalho se baseou em duas premissas: (i) O aquecimento global é um fenômeno provocado por um desequilíbrio no balanço de radiação terrestre. Quaisquer atividades que promovam este desequilíbrio contribuem também para o aquecimento global; (ii) materiais comumente usados na infraestrutura urbana de transportes, de coloração escura como o asfalto, possuem uma baixa capacidade de refletir radiação.

Foram determinadas também duas hipóteses principais: (i) a escolha de materiais corretos para o desenvolvimento da infraestrutura de transportes é capaz de minimizar os impactos deste setor no aquecimento global; (ii) A melhor disposição urbana, minimizando a área construída destinada ao setor de transportes é capaz de minimizar os impactos deste setor no aquecimento global.

\subsection{Objetivos: Geral e Específico}

Em linhas gerais, pode-se dizer que o objetivo geral deste trabalho é discorrer sobre os impactos do setor de transporte no aquecimento global. No entanto, conforme já comentado a abordagem deste trabalho foca no impacto da infraestrutura urbana de transportes no aquecimento global. Para isto, determinam-se como objetivos específicos: (i) avaliar como a infraestrutura de transportes urbana influencia o aquecimento global; (ii) analisar as medidas de mitigação atualmente propostas (iii) a realização de um estudo de caso para exemplificar os impactos da infraestrutura urbana de transporte apresentados.

Por fim, a partir deste trabalho espera-se contribuir para uma análise mais ampla e completa sobre o impacto do setor de transportes no aquecimento global. 


\subsection{Justificativa}

A justificativa para a realização deste trabalho é a importância dos impactos provenientes do aquecimento global e a contribuição das cidades para este fenômeno. Por mais que toda a atenção esteja voltada para as emissões de GEE, essa pesquisa irá ressaltar que essa não é a única fonte de contribuição antrópica para o problema. No caso do setor de transportes, um exemplo disto é o impacto oriundo da construção de sua infraestrutura urbana.

Dentro deste setor, ainda que o foco se concentre nas emissões de GEE e no elevado consumo de energia, também existem outros pontos que devem ser estudados e considerados para que este possa se adaptar e mitigar sua contribuição no aquecimento global. Destacam-se aqui: (i) o material e a cobertura usada para sua infraestrutura, capazes de alterar o albedo da superfície terrestre; (ii) e o potencial de induzir o crescimento e organização urbana deste setor.

Desta forma, essa pesquisa irá proporcionar uma nova visão e perspectiva sobre o impacto do setor de transporte no aquecimento global, analisando esta contribuição de uma forma mais completa. Esta análise se faz importante visto que, apesar da importância já reconhecida internacionalmente, ainda são escassos os estudos e publicações nacionais voltadas para o papel da infraestrutura de transporte no aquecimento global.

\subsection{Delimitação da pesquisa}

Do ponto de vista teórico, a abrangência da pesquisa buscará entender como a infraestrutura urbana de transportes influencia o aquecimento global, apresentando também algumas medidas de mitigação. Neste sentido, primeiramente, faz-se necessário estudar o fenômeno do aquecimento global. No entanto, visto que este fenômeno é abrangente em suas origens e impactos, o estudo buscará identificar principalmente o papel da infraestrutura de transportes no uso do solo urbano.

A pesquisa irá se concentrar geograficamente em espaços urbanos, sejam eles de países desenvolvidos ou em desenvolvimento. Ressalta-se aqui a delimitação geográfica particular do estudo de caso apresentado. Este apresenta o papel da infraestrutura urbana de transportes no aquecimento global, restrito a cidade do Rio de Janeiro. A pesquisa não possui uma delimitação temporal restrita, neste sentido, esta foi definida segundo o material recolhido.

\subsection{Metodologia}

Para a realização deste trabalho foi feita inicialmente a coleta do referencial teórico. Sendo assim, são caracterizados segundo fontes reconhecidas, nacional e internacionalmente os conceitos e temas tratados ao longo da pesquisa. A elaboração da base teórica fundamenta no decorrer da pesquisa, o papel de cada um dos agentes envolvidos no aquecimento global, 
principalmente aqueles ligados ao espaço urbano. É importante ressaltar que no referencial teórico ligado ao papel da infraestrutura urbana de transportes são utilizados principalmente artigos publicados em periódicos internacionais, devido à ausência de material nacional. No que se refere a análise de possíveis medidas de mitigação, além de artigos internacionais, o material estudado é constituído também de relatórios publicados por instituições reconhecidas internacionalmente.

Do ponto de vista da abordagem do problema, esta pesquisa se classifica como qualitativa, uma vez que seus resultados não poderão ser quantificados. Ressalta-se aqui, que o estudo de caso apresentando neste trabalho, apesar de apresentar resultados quantitativos, é apenas um exemplo dentro da visão geral da abordagem do problema. No tocante aos seus objetivos, esta pesquisa é de caráter exploratório, visto que será baseada em uma ampla pesquisa bibliográfica, elucidando os temas tratados; descritiva, dado que descreve a importância da infraestrutura de transportes no aquecimento global, estabelecendo relações entre os diferentes fatores envolvidos.

Esta pesquisa pode ser considerada de natureza básica. Isto, tendo em vista que o setor de transportes provoca impactos globais e que o aquecimento global também é um fenômeno mundial, esta dissertação envolve verdades e interesses universais. Apesar de apresentar propostas de mitigação destes impactos, não existe nenhuma aplicação prática prevista para a mesma.

No tocante aos procedimentos técnicos: a revisão bibliográfica foi realizada com o objetivo de apresentar o que já foi analisado sobre o tema, justificando sua importância. A pesquisa documental foi realizada para a utilização de dados de fontes mesmo que não receberam tratamento analítico, principalmente referente aos dados de emissão de radiação dos materiais. Esta pesquisa realizou também um estudo de caso, de forma a fornecer um exemplo do conhecimento específico e detalhado do impacto da infraestrutura de transportes no aquecimento global de uma determinada localização, no caso, a cidade do Rio de Janeiro.

\subsection{Estrutura do documento}

Este trabalho é constituído de 5 capítulos, incluindo esta introdução (Capítulo 1). O capítulo 2 apresenta o que são as mudanças climáticas e o aquecimento global, discorrendo sobre a evolução das emissões dos gases poluentes assim como a evolução da participação antrópica no fenômeno. Em seguida, apresenta como funciona o sistema climático e a sua relação com o aquecimento global. Por fim, o capítulo trata sobre evolução da preocupação 
histórica com o tema do aquecimento global apresentando, por exemplo, as diferentes negociações internacionais acerca do tema.

O capítulo 3 trata das mudanças climáticas e a importância da urbanização. Desta forma, discorre sobre a parcela de emissões de GEE nas cidades, apresentando também a contribuição do transporte urbano. Como exemplo, apresenta inventários de emissões de gases de efeito estufa de cidades como Rio de Janeiro, São Paulo, Belo Horizonte e Recife. Em seguida, o capítulo aborda exclusivamente o impacto da infraestrutura de transporte no aquecimento global. Neste ponto, caracteriza esta infraestrutura em diferentes cidades ao redor do mundo e apresenta diversos autores que abordam este tema. Por fim, o capítulo apresenta algumas políticas de mitigação do impacto da infraestrutura urbana de transportes no aquecimento global conhecidas atualmente.

O capítulo 4 é dedicado à apresentação do estudo de caso do impacto da infraestrutura urbana de transportes no Rio de Janeiro e sua contribuição para o aquecimento global. Sendo assim, apresenta inicialmente uma contextualização sobre a área de estudo seguida da apresentação separada de cada um dos fatores utilizados para o cálculo deste impacto. $\mathrm{O}$ capítulo encerra então, com algumas considerações finais acerca dos resultados apresentados no estudo de caso.

O Capítulo 5 encerra este trabalho, com a apresentação das conclusões e considerações finais sobre o mesmo, assim como a apresentação das limitações deste estudo e recomendações para futuras pesquisas. 


\section{Capítulo 2: Sistema Climático, Aquecimento Global e}

\section{Forçantes Radiativas}

\subsection{Panorama Inicial do aquecimento global e mudanças climáticas}

As mudanças climáticas são um dos problemas ambientais mais complicados e desafiantes do nosso tempo. Isto porque, dentre tantos motivos a serem aqui apresentados, serão as gerações futuras que sofrerão o efeito de "nossas" ações ou inações (Costa, 2004). Este capítulo apresenta as mudanças climáticas e o aquecimento global a partir da evolução das emissões de Gases de Efeito Estufa (GEE), analisando quando essas emissões começaram a crescer e relatando a importância da participação antrópica nessas emissões através das suas diferentes fontes. Para tal análise, apresenta o sistema climático e os diversos fatores que o influenciam. Em seguida, o capítulo apresenta a evolução histórica do conhecimento científico e as consequentes negociações internacionais através da análise de acordos e conferências internacionais realizadas com o intuito de mitigar e adaptar a participação antrópica nas mudanças climáticas.

Primeiramente, faz se necessário explicar a distinção entre os conceitos de mudanças climáticas e aquecimento Global. Segundo Barry e Chorley (2013), as mudanças climáticas são variações estatisticamente significativas no estado médio do clima ou em sua variabilidade, que persiste por um período prolongado, geralmente décadas ou mais. As mudanças climáticas podem ser decorrentes de processos internos naturais, forçantes externas naturais ou mudanças antropogênicas persistentes na composição atmosférica ou no uso da terra. O IPCC (Painel Intergovernamental sobre Mudanças Climáticas) define o aquecimento global como um aumento na temperatura da superfície terrestre ocasionado pelo desequilíbrio do balanço de radiação, resultado de um aumento na radiação terrestre retida na atmosfera (IPCC, 2007). Pode-se dizer então, que o aquecimento global é um dos efeitos das mudanças climáticas.

O equilíbrio da radiação no sistema climático ocorre em grande parte devido aos gases que aprisionam a radiação solar refletida pela Terra e promovem o efeito estufa, fenômeno responsável por garantir temperaturas agradáveis a permanência do homem na Terra (Silva, 2013 e Barry e Chorley, 2013). O principal gás de efeito estufa é o vapor d'agua (H20), responsável por 65\% do efeito estufa natural (Matos, 2001). No entanto, destacam-se aqui, os gases dióxido de carbono $\left(\mathrm{CO}_{2}\right)$, o metano $\left(\mathrm{CH}_{4}\right)$ e o óxido nitroso $\left(\mathrm{N}_{2} \mathrm{O}\right)$ dado que eles são os principais gases de efeito estufa de origem antrópica. No caso do $\mathrm{CO}_{2}$, sua principal fonte de emissão é a queima de combustíveis fósseis, seguido pelo desflorestamento. $\mathrm{O}_{4} \mathrm{CH}_{4}$ émitido 
pelos aterros sanitários, pela digestão entérica animal e pela produção e distribuição de gás natural. $\mathrm{O}$ óxido nitroso é um gás produzido tanto por fontes naturais como antrópicas, uso de fertilizantes orgânicos e químicos; queima de combustíveis fósseis e biomassa são alguns exemplos de fontes de emissões antrópicas (Matos, 2001).

A tabela a seguir apresenta esses gases e o seu respectivo potencial de aquecimento global (GWP). O potencial de aquecimento global é um índice elaborado com base nas propriedades radiativas dos gases de efeito estufa que mede o forçamento radiativo ${ }^{2}$ do gás comparado ao dióxido de carbono, para um determinado horizonte de tempo (IPCC, 2007b). Neste caso, os dois horizontes determinados são de 20 e 100 anos. A diferença no potencial de aquecimento global ocorre, pois, cada gás de efeito estufa irá impactar o sistema climático de maneira diferenciada, segundo seu tempo de permanência na atmosfera. Por exemplo, no caso do $\mathrm{CO}_{2}$, este tempo de permanência varia de 50 a 200 anos, enquanto que para o $\mathrm{CH}_{4}$ a sua permanência varia de 12 a 17 anos (Matos, 2001).

Tabela 1: Principais Gases de Efeito Estufa e respectivos Potenciais de Aquecimento Global (GWP)

\begin{tabular}{cccc} 
Nome do gás & $\begin{array}{c}\text { Fórmula } \\
\text { Química }\end{array}$ & $\begin{array}{c}\text { Global Warming Potential (GWP) para o } \\
\text { período determinado }\end{array}$ \\
& & 20 anos & 100 anos \\
\hline Dióxido de carbono & $\mathrm{CO}_{2}$ & 1 (por definição) & 1 (por definição) \\
\hline Metano & $\mathrm{CH}_{4}$ & $\sim 80$ & $\sim 30$ \\
\hline Óxido-Nitroso & $\mathrm{N}_{2} \mathrm{O}$ & $\sim 270$ & $\sim 300$ \\
\hline Tetrafluorometano & $\mathrm{CF}_{4}$ & $\sim 5.000$ & $\sim 7.000$ \\
\hline
\end{tabular}

Fonte: Adaptado de IPCC (2007)

Apesar de o efeito estufa ser um fenômeno natural indispensável para a vida na terra, a participação do homem, sobretudo pela queima excessiva de combustíveis fósseis e o desmatamento fizeram com que a concentração atmosférica desses gases tenha aumentado a valores insustentáveis (Silva, 2013). O IPCC aponta que essas emissões resultaram na maior concentração dos níveis de $\mathrm{CO}_{2}, \mathrm{CH}_{4}$ e $\mathrm{N}_{2} \mathrm{O}$ dos últimos 800.000 anos e nas maiores taxas

\footnotetext{
${ }^{2}$ Forçamento Radiativo é a variação no balanço de energia incidente e emergente na tropopausa. Este conceito é abordado detalhadamente na seção 2.3 deste capítulo.
} 
médias das concentrações desses gases registradas nos últimos 22.000 anos. Segundo o Observatório do Clima (2014), as emissões de mundiais de gases de efeito estufa cresceram $37 \%$ no período de 1990 a 2012, passando de $38 \mathrm{GtCO}_{2 \text { eq }}$ para $52 \mathrm{GtCO}_{2 \text { eq. }}$ Essas emissões contribuíram para um aumento médio da temperatura da terra na faixa de $0.5^{\circ} \mathrm{C}$ e $1.3^{\circ} \mathrm{C}$ no período de 1951 e 2010 (IPCC, 2014b).

O IPCC afirma que é altamente provável que mais da metade do aumento de temperatura observado no período acima comentado (1951 e 2010) tenha sido provocado pelo aumento da participação antrópica no aquecimento global. $\mathrm{O}$ marco do crescimento destas emissões foi a Revolução Industrial em meados de 1750, que instalou um modelo de crescimento com impactos diretos no meio ambiente. Segundo o IPCC, em 2011, as concentrações dos níveis de $\mathrm{CO}_{2}, \mathrm{CH}_{4}$ e $\mathrm{N}_{2} \mathrm{O}$ eram de $391 \mathrm{ppm}, 1803$ ppb e $324 \mathrm{ppb}^{3}$ respectivamente, valores 40\%, 150\% e 20\% maiores do que da era pré-industrial (IPCC, 2014c).

Ainda que a humanidade não tenha compreendido de que maneira e em que proporções suas ações influenciam as alterações no clima, já é cientificamente reconhecido que a ação do homem possui influência significativa no sistema climático (Silva, 2013). Nesta linha, apontase estudos como Barnett et al (1999); Ribeiro et al (2003); Rozenzweig et al (2008); Moser et al (2010); UN-HABITAT (2011); PBMC (2014b); Crowley (2014). Estes estudos analisam o equilíbrio do sistema climático e a participação antrópica neste sitema, reconhecendo não só a importância das mudanças climáticas como destacando a participação antrópica a estas mudanças.

A Figura a seguir apresenta as emissões antrópicas totais de gases de efeito estufa entre os anos de 1970 e 2010. Foram contabilizadas as emissões de $\mathrm{CO}_{2}$ provenientes da queima de combustíveis fosseis e processos industriais e oriundas de agricultura, florestas e outros usos da terra (AFOLU). Foram contabilizadas também as emissões do gás metano e óxido nitroso e os gases fluorados abrangidos no Protocolo de Quioto. O IPCC (2014c) destaca que neste período, os anos entre 2000 e 2010 registraram o maior aumento nessas emissões, apesar do número crescente de políticas de mitigação.

\footnotetext{
${ }^{3}$ Siglas utilizadas pelo IPCC cujos significados são: ppm - partes por milhão, ppb - partes por bilhão.
} 
Figura 1: Emissões Antrópicas de Gases de Efeito Estufa (1970-2010)

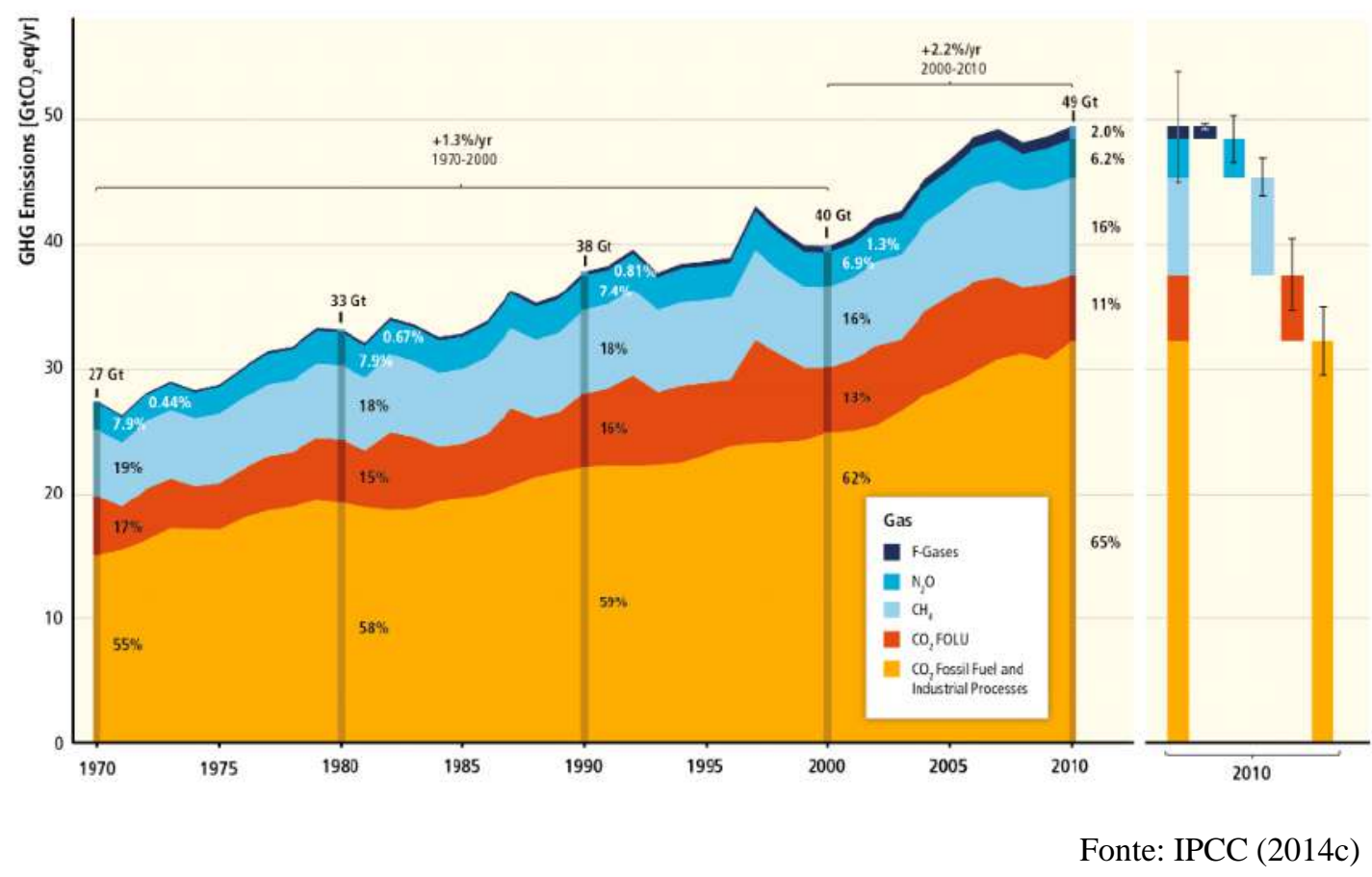

No caso do Brasil, no período de 1990 a 2012, as emissões brutas de gases de efeito estufa passaram de 1,39 $\mathrm{GtCO}_{2 \text { eq }}$ para $1,48 \mathrm{GtCO}_{2 \text { eq }}$, registrando um aumento de 7\% (PBMC, 2014a). Os gases $\mathrm{CO}_{2}, \mathrm{CH}_{4}$ e $\mathrm{N}_{2} \mathrm{O}$ representam 99,8\% dessas emissões. Dentro deste total, o principal deles é o $\mathrm{CO}_{2}$ que reponde por $64,4 \%$ das emissões totais seguido do $\mathrm{CH}_{4}$ que representa 23,1\% (Observatório do clima, 2014). Segundo o Painel Brasileiro de Mudanças Climáticas (PBMC, 2014a), a principal fonte de emissões de GEE no Brasil é o desmatamento. Por isso, os setores de mudanças no uso da terra e florestas (AFOLU) e agropecuária são os dois maiores emissores, seguidos pelos setores de energia, processos industriais e serviços.

Ao analisar a evolução das emissões dos setores brasileiros no período entre 1990 e 2012, observa-se que o setor de mudanças no uso da terra apresentou uma queda de $42 \%$ das emissões, enquanto os demais apresentaram uma tendência de crescimento (Observatório do Clima, 2014). O setor de agropecuário registrou uma alta de $45 \%$ e os setores de resíduos e processos industriais aumentaram respectivamente $64 \%$ e $65 \%$. Destaca-se aqui, as emissões do setor de energia, que cresceram 126\% neste mesmo período (Observatório do Clima, 2014).

É importante mencionar que estes dados apresentados pelo Observatório do Clima seguem uma metodologia diferenciada daquela utilizada pelo Ministério da Ciência, Tecnologia e Inovação (MCTi). Isto é, os dados oficiais publicados pelo MCTi em 2014 são referentes as emissões de gases de efeito estufa no período de 1990-2005 e 2005-2012 (tabela 2). Segundo 
este relatório, a contribuição do setor de energia nas emissões de gases de efeito estufa passou de $16 \%$ para $37 \%$. O setor que apresentou redução mais significativa na parcela de emissões foi o Uso da Terra e Florestas, que diminuiu de $58 \%$ para $15 \%$.

Segundo Azevedo (2013) este aumento expressivo das emissões no setor de energia pode ser explicado pelo crescimento das emissões de transportes no mesmo período, sobretudo devido ao consumo da gasolina. A redução nas emissões do setor de mudanças no uso da terra pode ser atribuída a queda nos níveis de desmatamento nacional, resultantes de esforços governamentais como a aplicação de leis e regulamentos que impedem o desmatamento ilegal (PBMC, 2014b).

Tabela 2: Variação nas emissões de $\mathrm{CO}_{2 \text { eq }}$ por setor

\begin{tabular}{ccc}
\multirow{2}{*}{ Setores } & \multicolumn{2}{c}{ Variação } \\
\cline { 2 - 3 } & $1995-2005$ & $2005-2012$ \\
\hline Energia & $44,3 \%$ & $35,9 \%$ \\
\hline Processos Industriais & $23,6 \%$ & $9,5 \%$ \\
\hline Agropecuária & $23,8 \%$ & $7,4 \%$ \\
\hline Florestas & $-39,2 \%$ & $-85,1 \%$ \\
\hline Resíduos & $24,4 \%$ & $18,8 \%$ \\
\hline Total & $-21,4 \%$ & $-41,1 \%$ \\
\hline
\end{tabular}

Fonte: Adaptado de MCTi (2014)

\subsection{Sistema climático e aquecimento global}

A medida do estado de equilíbrio climático da terra é a média global anual da temperatura do ar junto à superfície terrestre (Barry e Chorley, 2013). Conforme aponta Matos (2001), o clima no planeta Terra varia entre períodos mais quentes e eras glacias que podem durar entre uma década e milhares de anos. De forma geral, tem-se o sistema climático como um sistema dinâmico que reage em diferentes proporções de tempo e magnitude as constantes forças motrizes e as perturbações que a atingem (Barry e Chorley, 2013 e Matos, 2001).

O sistema climático é formado por cinco componentes que interagem entre si através de processos físicos, químicos e biológicos. Esta interação ocorre, por exemplo, através da transferência de matéria (os diferentes gases que compõem a atmosfera e a água) e de energia (recebe energia do sol em forma de radiação ultravioleta e emite a radiação de volta em forma de radiação infravermelha) (Amorim, 2011 e Barry e Chorley, 2013). O sistema climático é 
caracterizado pela variabilidade em diversas escalas temporais e espaciais, variações de temperatura anuais ou mesmo decenais podem ocorrer devido a processos puramente internos ao sistema climático.

Conforme aponta o PBMC (2014c), fatores naturais ou antrópicos podem induzir mudanças climáticas em escalas de milhares, centenas ou dezenas de anos. Citam-se como exemplos os casos da tectônica de placas em contraponto às atividades antrópicas que promovem alteração na composição atmosférica, como a emissão de GEE ou no uso do solo, como o desmatamento (Barry e Chorley, 2013). No caso das tectônicas de placas, apesar de influenciarem a circulação global da atmosfera e o padrão de circulação oceânica, seu papel nas mudanças climáticas dos últimos 100 anos ou nas projeções ao longo do século XXI são irrelevantes. Em contrapartida, algumas das atividades antrópicas, como a queima de combustíveis fósseis e o desflorestamento, têm efeito imediato e em nível global sobre o balanço de radiação no topo da atmosfera.

Como Barry e Chorley (2013) apresentam, o tempo de resposta do sistema climático é o que determina respostas a perguntas cruciais como quanto a temperatura global irá variar? Ou, quanto tempo leva para essa mudança ocorrer? A tabela 2 apresenta algumas características dos diferentes subsistemas do sistema climático, assim como seus respectivos tempos de resposta. Ressalta-se assim, que para entender o sistema climático é importante levar em consideração escalas de tempo e espaço. 
Tabela 3: Elementos do Sistema Climático e suas características

Tempo de resposta no sistema

Características climático

\begin{tabular}{|c|c|c|}
\hline & & \\
\hline & A atmosfera é o componente & O tempo de resposta da atmosfera é da \\
\hline & central do sistema climático. É & ordem de dias a semanas devido à sua \\
\hline & uma camada gasosa distribuída & compressibilidade relativamente grande e \\
\hline \multirow[t]{4}{*}{ Atmosfera } & quase uniformemente sobre a & baixo calor específico e densidade. Estas \\
\hline & superfície do planeta, com & propriedades tornam a atmosfera mais fluida \\
\hline & $99 \%$ de sua concentração & e instável. \\
\hline & abaixo de $30 \mathrm{~km}$. & \\
\hline
\end{tabular}

A hidrosfera consiste de toda

A resposta ou tempo de relaxação para os

água na fase líquida distribuída

oceanos varia numa faixa de tempo elevado,

na Terra. Destacam-se os

que se estende de semanas a meses ou a

Hidrosfera oceanos, por causa da grande massa e calor específico, que centenas e milhares de anos no oceano profundo.

constituem um enorme

reservatório de energia.

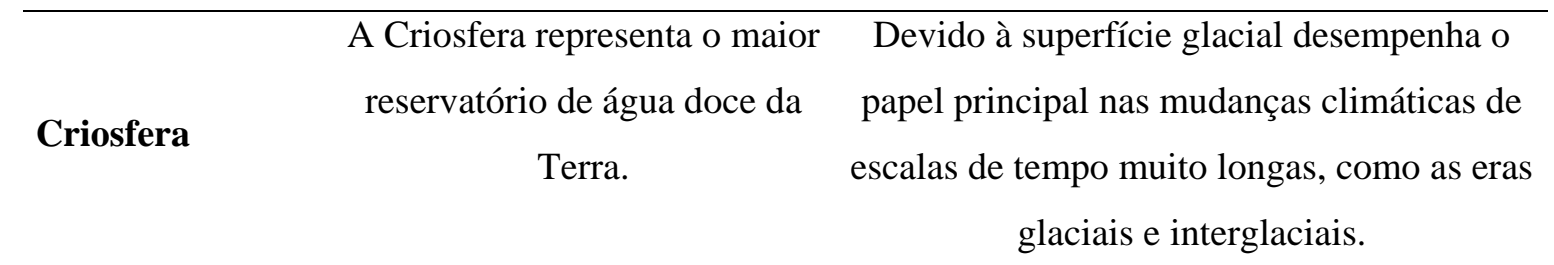

\begin{tabular}{ccc}
\hline Litosfera & $\begin{array}{c}\text { Inclui os continentes cuja } \\
\text { topografia afeta os } \\
\text { movimentos do ar, e o solo do } \\
\text { oceano. }\end{array}$ & $\begin{array}{c}\text { Possui o maior tempo de resposta de todos } \\
\text { os componentes do sistema climático. } \\
\text { Possui um ritmo de incorporação e perda de } \\
\text { carbono extremamente lento. }\end{array}$ \\
\hline Biosfera & Compreende a vegetação & $\begin{array}{c}\text { Agente capaz de impor perturbações } \\
\text { terrestre, a fauna continental e e }\end{array}$ \\
a flora e fauna dos oceanos. & $\begin{array}{c}\text { agressivas ao ciclo, devido à escala temporal } \\
\text { com que trabalha. Historicamente, foi } \\
\text { responsável por proporcionar à atmosfera a } \\
\text { composição de gases atual. }\end{array}$
\end{tabular}

Fonte: Adaptado de Amorim (2011)

A temperatura do planeta terra é resultado do balanço entre a energia emitida pelo sol que é absorvida pela superfície terrestre e a energia que é refletida de volta para o espaço. Conforme aponta Amorim (2011), o principal componente do equilíbrio radiativo terrestre é a atmosfera, devido à sua habilidade no controle de energia global. A figura a seguir apresenta o 
equilíbrio radioativo terrestre, ressaltando a participação de nuvens, aerossóis e os gases de efeito estufa no controle da radiação que entra e sai da superfície terrestre.

Figura 2: Equilíbrio Radioativo Terrestre

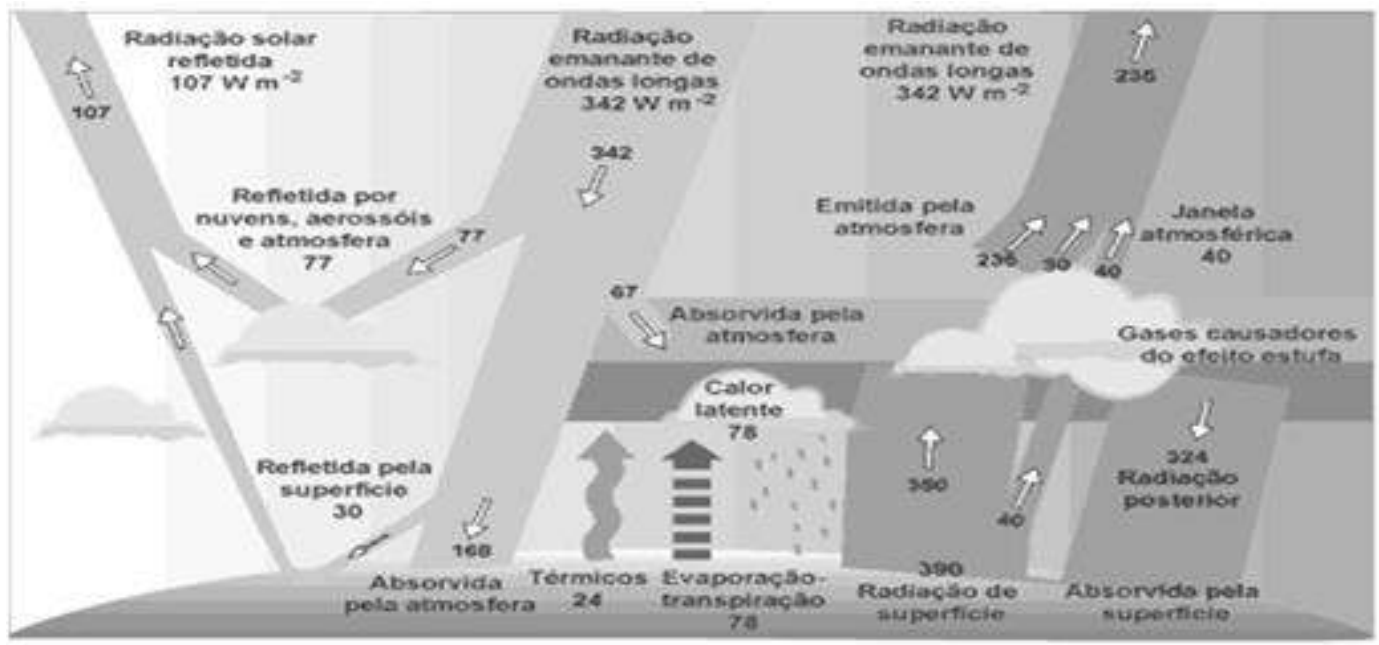

Fonte: Artaxo (s.d)

O desequilíbrio deste sistema que resulta no aquecimento ou esfriamento da temperatura na Terra é provocado pelas chamadas forçantes radiativas. As forçantes radiativas podem ser de origem natural, como erupções vulcânicas ou antrópicas, como pela queima de combustíveis fósseis. Uma forçante radiativa positiva significa que o agente tende a aquecer o planeta, ao passo que valores negativos indicam uma tendência de resfriamento (Nobre, 2012). A seção seguinte apresenta algumas dessas forçantes e suas relações com o sistema climático.

\subsection{Forçantes radiativas do sistema climático e o aquecimento}

\section{global}

O IPCC (2013) aponta que há uma variedade de maneiras de examinar como os vários fatores climáticos contribuem para as alterações no clima. No entanto, como a seção anterior mostrou, o sistema climático é resultado da interação entre diversos fatores, o que torna extremamente difícil avaliar o impacto de cada um deles individualmente. O IPCC criou então a medida de forçante radiativa que permite a percepção da influência quantitativa de cada agente climático de uma maneira mais objetiva. Esta medida classifica os agentes mais significativos segundo uma ordem de magnitude relativa. Segundo o PBMC (2014c) calcular a forçante radiativa de um agente climático é como definir uma escala padrão que permite a possibilidade de estimar a intensidade de sua perturbação sobre o clima. 
Apesar da dificuldade de identificar seus efeitos diretos no clima, dado que a medida é normalmente expressa em termos de $\mathrm{Wm}^{2}$, as forçantes radiativas facilitam as análises dos tomadores de decisão, tendo em vista que não precisam necessariamente dos modelos climáticos. Define-se então, conforme o IPCC (2013), o forçamento radiativo como a variação líquida no balanço energético do sistema Terra, devido a alguma perturbação imposta. As forçantes radiativas, por sua vez, são os fatores, naturais ou antrópicos, que influenciam o equilíbrio do balanço energético.

A Figura 3 apresenta essas forçantes e mostra como estas influenciam o aquecimento global. As forçantes com valores assinalados em azul contribuem para o esfriamento do sistema climático; já quando a forçante aparece em vermelho, o impacto se dá no sentido contrário, de elevar a temperatura global.

Figura 3: Forçantes Radiativas do Sistema Climático

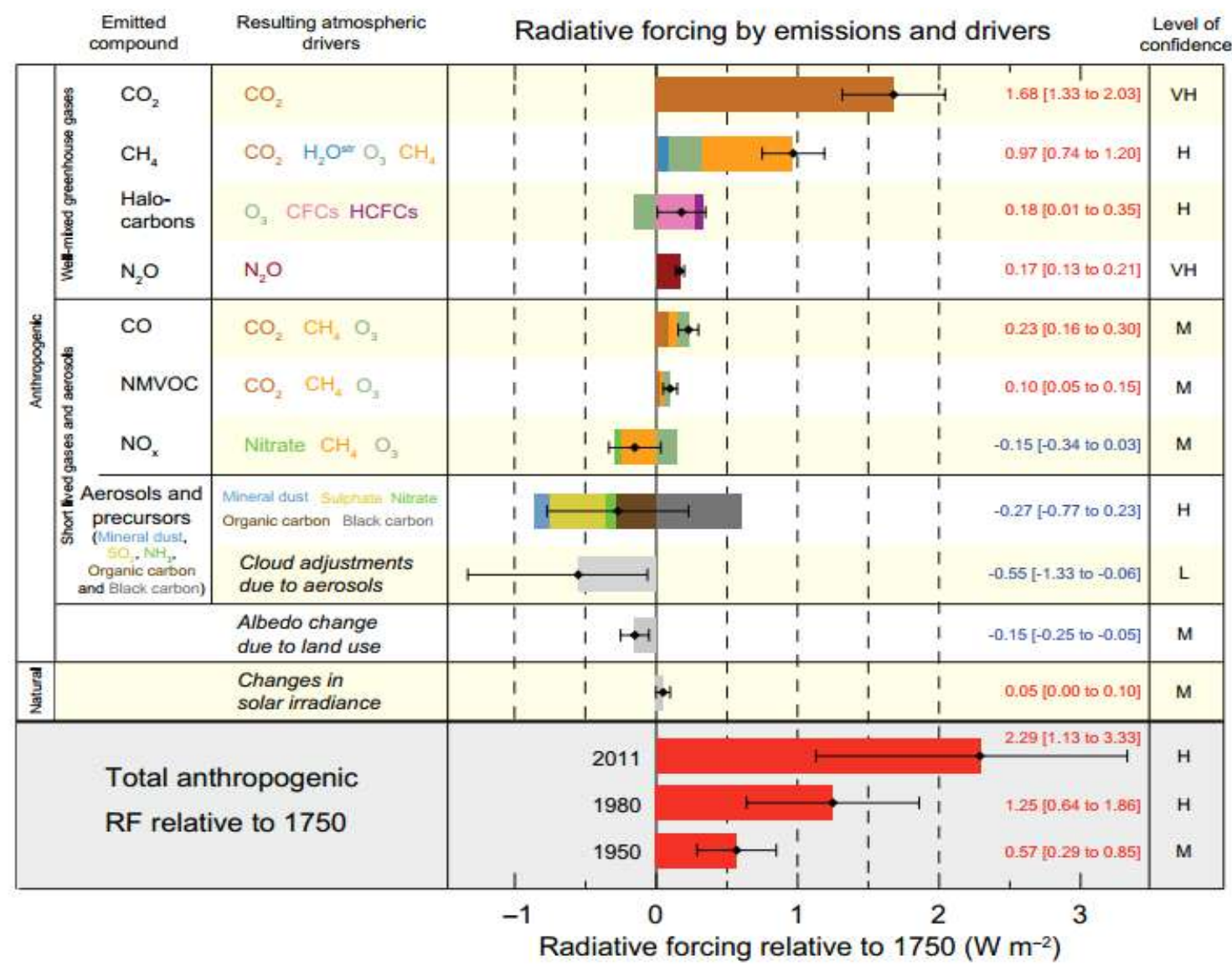

Fonte: IPCC (2013)

Segundo o IPCC (2007), a forçante radiativa climática total é de $1.6 \mathrm{Wm}^{2}$, o que provocou um aumento médio na temperatura global de cerca de 0,76 graus Celsius no período 
entre os anos de 1750 e 2005. Estima-se que em 2021 o total da forçante radiativa antrópica seja $43 \%$ maior do que o havia sido estimado para o ano de 2005 (IPCC, 2013). Como mostra a figura anterior, a principal contribuição antrópica positiva são as emissões de gases de efeito estufa, chamados pelo IPCC de "Well-mixed greenhouse gases" (WMGHGs), enquanto os aerossóis e o albedo da superfície são reconhecidos como forçantes antrópicas negativas (IPCC, 2014c).

A participação antrópica na acumulação dos gases de efeito estufa na atmosfera contribuiu expressivamente para o aumento da temperatura da superfície terrestre, e, conforme mencionado pelo IPCC, a tendência é que a sua participação cresça cada vez mais. O forçamento radiativo total provocado pelos gases de efeito estufa é de $+2.83 \mathrm{Wm}^{2}$, sendo que esta medida aumentou em $8 \%\left(0.20 \mathrm{Wm}^{2}\right)$ desde 2005. As emissões de $\mathrm{CO}_{2}$ são a principal forçante radiativa desde a década de 1960 , e seu forçamento cresceu $0.27 \mathrm{Wm}^{-2}$ na última década. $\mathrm{O}$ forçamento dos outros gases de efeito estufa cresceram a taxas menores, os gases metano e oxido nitroso cresceram a taxas de $2 \%$ e $6 \%$ respectivamente (IPCC, 2013).

Os aerossóis são definidos como a suspensão de partículas sólidas ou liquidas em um gás e possuem efeito direto e indireto no clima. O efeito direto está relacionado ao espalhamento e absorção da radiação solar antes que esta atinja a superfície do planeta, resfriando a superfície e aquecendo a atmosfera. O efeito indireto está relacionado à sua interação com as nuvens, alterando suas propriedades radiativas e tornando-as mais altas e esparsas, além de afetar seu tempo de vida e seu potencial de reflexão (CEPAC, s.d.). Como pode ser observado na figura 3 , estes são uma forçante negativa, mas é importante mencionar que ainda existem muitas incertezas em relação à quantificação dos efeitos dos aerossóis sobre o clima.

A outra forçante radiativa de origem antrópica é a variação do albedo da superfície. O albedo da superfície é a razão entre a radiação refletida pela superfície e a radiação solar total incidente sobre a mesma (IPCC, 2013). O albedo varia de acordo com a cobertura da superfície, por exemplo: as florestas costumam ser mais escuras do que gramíneas ou terras agrícolas e por isso possuem um albedo menor e absorvem mais radiação. Por isso, o desmatamento contribui para o aumento do albedo da superfície terrestre. $\mathrm{Na}$ escala de cidades, esta comparação pode ser feita pelas superfícies escuras, como concreto ou asfalto, que absorvem muita radiação, em contraponto a áreas de parques urbanos, que costumam apresentar temperaturas mais amenas.

Na Figura 3, o impacto da alteração do albedo da superfície terrestre está caracterizado como uma forçante radiativa negativa. Segundo o IPCC (2013), a melhor estimativa para o potencial de forçamento radiativo da mudança no uso da terra está entre $-0.2 \pm 0.2 \mathrm{~W} \mathrm{~m}^{-2}$ com 
ano base de 1750. Ressalta-se aqui que, apesar do alto nível de emissão, o desmatamento e a consequente diminuição de áreas com baixo albedo, ainda que em uma escala consideravelmente inferior, contribui positivamente para o aumento do potencial da superfície terrestre de refletir a radiação recebida. Em contrapartida, com o crescimento expressivo dos centros urbanos, espaços que retêm proporcionalmente mais calor, devido à grande proporção de superfícies escuras, a quantidade de radiação retida na superfície terrestre tende a ser cada vez maior, provocando um aumento na temperatura da superfície terrestre. Ou seja, contribuindo para o aquecimento global.

\subsection{Evolução da preocupação histórica com o tema: conhecimento científico e} negociações internacionais

Segundo Lago (2013), a Conferência de Estocolmo em 1972 foi o primeiro sinal da preocupação das Nações Unidas com os impactos ambientais causados pelo modelo crescimento econômico. Destacam-se entre as maiores conquistas desta conferência, o estímulo à criação de órgãos nacionais dedicados à questão de meio ambiente, o fortalecimento das organizações não governamentais e a criação do Programa das Nações Unidas para o Meio Ambiente (PNUMA).

Outro grande marco acerca da preocupação com o tema das mudanças climáticas foi a criação do Painel Intergovernamental sobre Mudanças Climáticas (IPCC) em 1988, pelo recémcriado PNUMA. Este painel, formado por cientistas de mais de 130 países tem por objetivo estudar os fenômenos relacionados às mudanças climáticas. O IPCC é organizado em três grupos de trabalho (GT- I, II, III) responsáveis por diferentes áreas da análise climática. Em linhas gerais, pode-se dizer que o GT I fornece a base científica das mudanças climáticas, o GT II, avalia a vulnerabilidade dos sistemas frente a essas mudanças assim como possíveis medidas de mitigação; e o GT III é responsável pela análise das possibilidades de medidas de mitigação (Portal Brasil, 2010).

A principal contribuição do IPCC são os relatórios científicos publicados, que contribuem para o direcionamento de práticas de adaptação e mitigação das mudanças climáticas. Estes relatórios servem como base, por exemplo, para as diversas conferências internacionais sobre as mudanças climáticas. O primeiro relatório publicado pelo IPCC foi em 1990 e serviu como base para conferência sobre meio ambiente organizada pela ONU, a Conferência do Rio, em 1992, conhecida como Rio 92. Dentre os resultados desta conferência 
destaca-se a formação da Convenção Quadro das Nações Unidas sobre Mudanças Climáticas (CQNUMC).

A Convenção Quadro das Nações Unidas sobre Mudanças Climáticas é, até hoje, um dos acordos com maior visibilidade no cenário internacional. Firmada por 186 países, a CQNUMC é um acordo mundial cujo objetivo é dar suporte aos países envolvidos para estabilizar a interferência humana das emissões de GEE no sistema climático (Costa, 2004 e Biato, 2005). Esta convenção separou pela primeira vez os países membros em dois grupos: países Anexo I e países não anexo I. Os países Anexo I eram os países "ricos" e industrializados enquanto os países não anexo I eram todos os países restantes, ainda em desenvolvimento. A tabela 4 a seguir evidencia a grande diferença entre o total de emissão destes dois grupos.

Tabela 4: Maiores Emissores de Dióxido de Carbono (1990)

\begin{tabular}{|c|c|c|c|}
\hline \multirow[b]{2}{*}{ Parte Anexo I } & \multirow{2}{*}{$\begin{array}{l}\text { Emissões CO2 } \\
\text { (mil toneladas) }\end{array}$} & \multicolumn{2}{|c|}{ Participação (\%) sobre } \\
\hline & & Total Anexo I & Total Global \\
\hline EUA & 4.819 .166 & 34,5 & 21,6 \\
\hline Rússia & 3.708 .734 & 26,55 & 16,6 \\
\hline Japão & 1.071 .444 & 7,67 & 4,8 \\
\hline Alemanha & 1.012 .443 & 7,25 & 4,5 \\
\hline Reino Unido & 563.647 & 4,04 & 2,5 \\
\hline Canadá & 425.054 & 3,04 & 1,9 \\
\hline Itália & 399.142 & 2,86 & 1,7 \\
\hline Polônia & 347.838 & 2,49 & 1,5 \\
\hline Austrália & 266.203 & 1,91 & 1,1 \\
\hline Outros & 1.354 .931 & 9,7 & 6 \\
\hline Total Anexo I & 13.968 .605 & 100 & 62,6 \\
\hline Total Não-Anexo I & 8.322 .908 & & 37,3 \\
\hline Total & 22.291 .513 & & 100 \\
\hline
\end{tabular}

Fonte: Pereira e May (2003)

Tendo em vista a abrangência e a complexidade do tema das mudanças climáticas, os países membros da CQNUMC estabeleceram um grupo de acompanhamento das ações, conhecido como a Conferência das Partes (COP). Atualmente, a COP é o órgão supremo da CQNUMC e a autoridade mais alta para tomada de decisões referentes às mudanças climáticas (Costa, 2004). Dentre as conferências realizadas, destaca-se aqui, inicialmente a COP 3 , realizada em 1997 em Quioto, no Japão. Isto porque, foi nesta conferência que as partes 
firmaram o Protocolo de Quioto, o comprometimento dos países Anexo I e dos países não Anexo I da transição para economias de mercado com metas de redução das emissões de GEE (Costa, 2004).

Segundo o protocolo, os países industrializados deveriam reduzir suas emissões combinadas de gases de efeito estufa em pelo menos 5,2\% em relação aos níveis de 1990 no período compreendido entre 2008 e 2012 (Godoy e Pamplona, 2007). A União Européia assumiu o compromisso de reduzir suas emissões em 8\%; o Japão, Canadá e Hungria concordaram em reduzir 6\%. Em contrapartida, alguns países como a Rússia e Ucrânia não assumiriam compromisso de redução e outros como Islândia, Austrália e Noruega e segundo o documento, ainda teriam permissão para aumentar suas emissões em até 10\% (Gomes, 2005).

Apesar de firmado em 1997, o Protocolo apenas entrou em vigência em 2005, quando um total de 132 partes o ratificaram. No entanto, dado que dois grandes emissores, os EUA e a China, não aderiram o protocolo, quaisquer medidas de redução de emissão adotadas seriam insuficientes.

Criou-se então a necessidade de um novo acordo global ainda mais abrangente e eficiente, que reduzisse de forma significativa as emissões de GEE a partir de 2012. A expectativa da criação deste novo acordo foi então concentrada na realização da COP 15 , realizada em 2009 em Copenhagen. No entanto, como aponta Azevedo (s.d.) devido a um impasse entre os países desenvolvidos e em desenvolvimento, nenhum acordo foi assinado. Ainda assim, esta conferência ficou marcada pela determinação da meta de limitar o aumento da temperatura média global em $2^{\circ} \mathrm{C}$, conforme recomendado pelo $4^{\circ}$ relatório do IPCC (Kahn e Azevedo, s.d.).

O novo acordo com as metas de redução de emissão foi firmado então na COP 21 e ficou conhecido como o Acordo de Paris. Pode se considerar como peça chave deste novo plano global de redução de emissão as Contribuições Internacionais Nacionalmente Determinadas (INDCs, sigla em inglês). As INDCs são planos de ação elaborados por cada país voluntariamente que abordam uma série de questões que podem evitar, adaptar ou lidar com as mudanças climáticas (Azevedo, s.d.)

As INDCs foram apresentadas por quase todos os países do mundo e cobrem um total de quase $99 \%$ das emissões de poluentes globais. Desta forma, em relação ao Protocolo de Quioto, o Acordo de Paris possui como grande diferencial a sua abrangência. Destaca-se também a participação dos Estados Unidos, que apresentou em sua INDC o objetivo de reduzir suas emissões entre $26 \%$ e $28 \%$ em relação aos níveis de 2005 . Segundo o documento 
apresentado pelos EUA, espera-se atingir em 2020 uma redução de 17\% das emissões de GEE em relação aos níveis de 2005, restando uma redução de apenas 9\% a 11\% para a meta de 2025 (EUA, s.d.).

No caso brasileiro, foi apresentada uma meta ainda mais ambiciosa que a meta norte americana: uma redução até 2025 de $37 \%$ das emissões em relação aos níveis de 2005 . Esta meta já foi aprovada pela câmara e congresso brasileiros e tornou-se então NDC (sigla em inglês para Contribuição Nacionalmente Determinada) (Tolentino, 2016). As medidas de adoção apresentas na NDC brasileira estão relacionadas principalmente ao setor de energia e o setor florestal e de uso da terra. No setor energético, o Brasil pretende até 2030 alcançar uma participação de $45 \%$ de energia renovável na sua matriz energética, de forma que de $28 \%$ a $33 \%$ de sua energia sejam de fonte renováveis, além da energia hídrica (Brasil, s.d.). A tabela a seguir apresenta os níveis de emissão esperados e a porcentagem de redução das emissões em relação ao ano de 2005.

Tabela 5: NDC brasileira

NDC brasileira (Ano base: 2005)

\begin{tabular}{ccc}
\hline & Níveis de emissão & $\%$ \\
\hline 2005 & $2,1 \mathrm{GtCO}_{2 \mathrm{eq}}$ & - \\
\hline 2025 & $1,3 \mathrm{GtCO}_{2 \mathrm{eq}}$ & $37 \%$ \\
\hline 2030 & $1,2 \mathrm{GtCO}_{2 \mathrm{eq}}$ & $43 \%$ \\
\hline
\end{tabular}

Abrangência: Todo território nacional, para o conjunto da economia. Inclui gases $\mathrm{CO}_{2}, \mathrm{CH}_{3}, \mathrm{~N}_{2} \mathrm{O}$, Perfluocarbonos, hidrofluocarbonos e $\mathrm{SF}_{6}$

Fonte: Brasil (s.d.)

Estudos apontam que mesmo com o cumprimento das INDCs, a temperatura global pode subir além dos 2 graus Celsius esperados pelo Acordo de Paris. O estudo de Rogelj et al (2016) aponta que em um cenário sem o controle de emissões, a temperatura global poderia subir entre 4.1 e 5.6 graus Celsius já em um cenário com essas INDCs, estes números variam entre 2.9 e 4.4. graus Celsius. Percebe-se, portanto, que apesar das medidas propostas contribuírem consideravelmente para a mitigação do aquecimento do planeta, são necessários esforços ainda maiores. 


\section{Capítulo 3: As cidades e o Aquecimento Global}

\subsection{Mudança Climática e Urbanização}

Segundo a ONU (UN-HABITAT, 2015b), em 1950 a população urbana mundial era de 756 milhões de habitantes e representava apenas 30\% da população total. Este número cresceu e, segundo o documento, em 2014 a população urbana mundial subiu para 3.9 bilhões de pessoas, que representavam 54\% da população total. Em 1950 os habitantes dos centros urbanos ocupavam principalmente as áreas urbanas dos países desenvolvidos (58\%). No entanto, atualmente a cada 10 cidadãos urbanos, 7 estão em países em desenvolvimento. Seguindo esta tendência, espera-se que até 2050 as cidades recebam mais 2,5 milhões habitantes e representem $66 \%$ da população mundial (UN-HABITAT, 2015b).

O aumento maciço da população urbana irá implicar no aumento da demanda por infraestrutura, transporte e energia, que são importantes condutores de emissões de gases de efeito estufa. Desta forma, tal tendência de urbanização sugere que as áreas urbanas serão uma parte ainda mais importante das emissões globais. Destaca-se aqui, que o estudo da relação entre as cidades e as mudanças climáticas ainda é muito recente, e apesar de diversos autores abordem os impactos individuais de diferentes cidades, existem poucos estudos que examinem a contribuição global das cidades ao aquecimento global (IPCC, 2014a).

O IPCC (2014a) aponta dois fatores que dificultam a determinação da contribuição das cidades as mudanças climáticas: a complexidade de delimitar as emissões das fronteiras urbanas e rurais e a grande restrição de dados sobre as emissões urbanas de gases de efeito estufa. Somam-se a estes, segundo Dodman (2009), a ausência de uma métrica padrão para o desenvolvimento de inventários na escala de cidades, como ocorre no caso dos inventários nacionais. Desta forma, os inventários de emissões em diferentes cidades podem utilizar diferentes metodologias, diferentes fronteiras espaciais e funcionais além de incluir diferentes atividades. Essa falta de padrão provoca diferenças diretas em sua elaboração o que não permite a análise e comparação direta entre eles (Dodman, 2009 e IPCC, 2014a).

Um estudo que estimou as emissões globais totais de gases de efeito estufa, foi elaborado por Marcotullio et al (2013). De acordo com o estudo, as atividades urbanas respondem por um total entre $36,8 \%$ e $48,6 \%$ das emissões totais de GEE. Neste estudo, foram encontradas diferenças significativas relacionadas às emissões de países desenvolvidos e de países em desenvolvimento, aos setores de origem e as regiões geográficas. Dentre estas 
diferenças, destaca-se que as 50 maiores áreas urbanas emissoras, são responsáveis por 38.8\% das emissões urbanas totais ${ }^{4}$ (Marcotullio et al., 2013).

As emissões antrópicas totais de GEE calculadas foram de aproximadamente 34.8 bilhões de $\mathrm{tCO}_{2 \text { eq }}$ das quais entre 12.8 e 16.9 bilhões de $\mathrm{tCO}_{2 \text { eq }}$ ocorreram nas áreas urbanas. Uma análise sobre as regiões permite concluir que as emissões urbanas dos países em desenvolvimento correspondem em média por 26 a 33\% das emissões totais, enquanto nos países desenvolvidos essa porcentagem representa em torno de 47 a $63 \%$ do total (Marcotullio et al., 2013). O estudo destaca então dois exemplos extremos que são o caso das regiões da África e da América do Norte, cujas emissões urbanas representam respectivamente em torno de 21 a $30 \%$ e 49 a $73 \%$ das emissões totais. A tabela a seguir apresenta a porcentagem das emissões urbanas por setor nas diferentes regiões geográficas mundiais.

Tabela 6: Porcentagem de emissões urbanas por região geográfica (2000)

\begin{tabular}{cccccccc} 
& \multicolumn{1}{c}{ América } & \multicolumn{3}{c}{ América } \\
& África & Ásia & $\begin{array}{c}\text { Latina e } \\
\text { Caribe }\end{array}$ & Europa & do & Oceania & Mundial \\
Agricultura & 2,4 & 6 & 2,2 & 9 & 5 & 4,9 & 5,3 \\
\cline { 2 - 8 } & 50,5 & 55 & 49,4 & 70,5 & 87,3 & 76,5 & 66,3 \\
\hline Energia & 40,5 & 30,4 & 33,3 & 47,5 & 50,9 & 25,4 & 38,1 \\
\hline Indústria & 14,5 & 24,7 & 27,1 & 40 & 60,3 & 33,3 & 36,9 \\
\hline Residencial & 30,4 & 34,3 & 38,9 & 47,3 & 68,4 & 56,3 & 50,9 \\
\hline Transportes & 18,7 & 32,6 & 40,4 & 40,5 & 64,1 & 50,9 & 38,8 \\
\hline Resíduos & 29,5 & 37,9 & 29,3 & 55 & 72,8 & 50,2 & 48,6 \\
\hline Total urbano & & & & & \multicolumn{2}{c}{ Fonte: Marcotullio et al (2013) }
\end{tabular}

A tabela anterior evidencia a participação expressiva das emissões oriundas do setor de energia, que representa a principal fonte de emissão em países desenvolvidos e em desenvolvimento. O IPCC (2014a) aponta que em 2005 o consumo de energia nas áreas urbanas foi de aproximadamente $76 \%$ do consumo global, resultando em um total aproximado de 12,5 Gt de $\mathrm{CO}_{2}$. Dentre essas emissões, ressalta-se a disparidade das emissões entre os países e regiões desenvolvidos e aqueles em desenvolvimento (IPCC, 2014a; IEA, 2008; Marcotullio et

\footnotetext{
${ }^{4} \mathrm{O}$ cálculo das emissões totais deste estudo foi baseado nas emissões do ano 2000 e excluiu as emissões da queima de biomassa em grande escala e as emissões da aviação e navegação que ocorrem sobre os oceanos. Foram consideradas apenas as cidades com mais de 50.000 habitantes.
} 
al, 2013). Desta forma, considerando a tendência de urbanização e o crescimento dos países em desenvolvimento nos moldes daqueles desenvolvidos, pode-se concluir que, se nada for feito, o impacto desse processo sobre o aquecimento global será significativo.

A importância das cidades como agentes impactantes no aquecimento global, já é amplamente reconhecida por toda comunidade acadêmica. Hebbert e Jankovic (2013) sugerem que não é de se surpreender que a descoberta das mudanças climáticas tenha coincidido com o ponto onde o número de moradores das cidades superou a população rural. Essa posição das cidades, como principal fonte das interferências antrópicas sobre o clima tem nas emissões de gases de efeito estufa a sua principal forma de contribuição. Todavia, destaca-se aqui, o papel duplo das cidades em relação ao aquecimento global. Isto porque, ao mesmo tempo em que as cidades concentram as maiores fontes de contribuição antrópica ao fenômeno, elas também sofrem com diversos de seus impactos (Santos, 2014).

Modelos sobre mudanças no padrão climático mostram com diferentes níveis de certeza que, no longo prazo ocorrerão diversos impactos nas cidades como, por exemplo, o aumento na frequência de extremos de temperatura (diário e sazonal), na intensidade de tempestades e ciclones tropicais e até o alagamento de áreas que hoje são secas (IPCC, 2007). Em linhas gerais, pode-se dizer que os efeitos destes impactos serão mais significativos em quatro setores na maioria das cidades: o sistema local de energia; demanda e fornecimento de água, e tratamento de esgoto; transporte e saúde pública (ROSENZWEIG et al., 2008).

Segundo While e Whitehead (2013), a perspectiva é que os impactos climáticos irão reforçar as desigualdades econômicas, sociais e de saúde já existentes, além de criar novas vulnerabilidades urbanas. Na mesma linha, entre os motivos de preocupação elencados nos relatórios do IPCC estão questões relacionadas à saúde humana, como a migração, o alastramento de doenças tropicais, problemas de segurança alimentar, e a redução no crescimento econômico global. Ambos os estudos destacam que estes problemas impactarão as cidades ao redor do mundo de maneira diferenciada.

Aspectos como a localização geográfica da cidade, características geomorfológicas do sítio urbano e a dimensão do contingente populacional são fatores que influenciam a vulnerabilidade das cidades às mudanças climáticas (UN-HABITAT, 2011). Marengo (2009) afirma que algumas comunidades e assentamentos pobres já se encontram sob o estresse da variabilidade climática e dos eventos extremos. Segundo o autor, estas áreas podem ser especialmente vulneráveis as mudanças climáticas porque concentram áreas de risco relativamente alto com limitado acesso a serviços e a outros recursos para solucionar danos. 
Soma-se a tal fato, a dependência de algumas regiões aos recursos sensíveis ao clima tais como o abastecimento local de água e alimentos (Marengo, 2009).

No caso brasileiro, os principais cenários de risco em áreas urbanas estão relacionados a enchentes e inundações, enxurradas com potencial de arraste, alagamentos e movimentos de massa em encostas (PBMC, 2014c). Outros impactos como a elevação do nível do mar e o aumento da temperatura também são apontados para o caso das cidades brasileiras por Ribeiro (2008). Marengo (2009) aponta que as grandes cidades brasileiras passaram por um processo rápido de urbanização, o que influenciou na presença de infraestrutura em áreas de risco ocupadas por assentamentos informais, fato que eleva o grau de vulnerabilidade da população.

Ressalta-se novamente que ao passo que as cidades influenciam ativamente nas mudanças climáticas, elas são também impactadas diretamente por seus efeitos. Essa posição das cidades, como principal fonte das interferências antrópicas sobre o clima tem nas emissões de gases de efeito estufa a sua principal forma de contribuição. No entanto, outro impacto proveniente das cidades que ganha cada vez mais espaço no debate sua influência sobre o clima e, em especial, o aquecimento global é o papel da urbanização (Hebbert e Jankovic, 2013).

O impacto das emissões de gases de efeito estufa nas cidades e os impactos oriundos do papel da urbanização serão aqui abordados sobre o ponto de vista dos transportes. Tal escolha se justifica ao analisar, além da elevada contribuição de gases de efeito estufa do setor, a importância deste como elemento vital para as cidades e seu desenvolvimento, assim como a alta capacidade do setor de transportes em ordenar o modelo de desenvolvimento urbano e os impactos a estes associados.

\subsection{Transporte Urbano e Emissão de $\mathrm{CO}_{2}$}

Como Santos (2014) aponta, o setor de transportes produz externalidades decorrentes de sua operação em áreas urbanas. Segundo a autora, o aumento da frota de veículos automotores em circulação tem contribuido para o crescimento das taxas de acidentes em áreas urbanas, assim como os custos de congestionamentos. Somam-se a estes, a poluição do ar e a poluição sonora nas cidades, os acidentes de trânsito e o estresse produzido por viagens longas e desconfortáveis (Balassiano, 2012). De acordo com o autor, estes impactos precisam ser monitorados e dentro do possível reduzidos.

Destacam-se aqui, entre os impactos do setor de transporte, o alto consumo de energia e as altas emissões de gases de efeito estufa oriundas do setor. Segundo o último relatório do IPCC (IPCC, 2014c), o setor de transporte é responsável por $27 \%$ da utilização final de energia 
global, das quais aproximadamente $70 \%$ são provenientes de combustíveis fósseis não renováveis, com alto nível de emissão de GEE. Segundo o relatório, as emissões de GEE do setor mais que duplicaram desde 1970 e a menos que haja uma grande mudança nos padrões do uso de energia, o consumo de energia do setor de transportes em 2030 será $80 \%$ maior do que atualmente.

Cada modal do setor de transporte apresenta uma intensidade energética específica. Isto é, alguns modais são mais intensivos em energia que outros. Um fato preocupante, como aponta Chapman (2007) é que apesar de todos os setores dos transportes estarem experimentando expansão, há uma tendência geral de que os modos que estão experimentando maior crescimento são os mais poluentes. Ressalta-se aqui que as cidades atualmente são planejadas visando principalmente o transporte por automóveis (Santos, 2014).

Segundo Matos (2001), essa dependência de um único tipo de combustível, o derivado do petróleo, é uma particularidade negativa do setor de transporte. Segundo a autora, outros tipos de combustível que não os derivados de petróleo são os dutos, que usam o gás natural para acionar os compressores, e o transporte ferroviário e metroviário, que utiliza a eletricidade. A figura a seguir mostra o consumo final de energia dos subsetores de transporte, em 2009, para transporte de passageiros e carga. Segundo o IPCC (2014b), mais de 53\% do consumo de petróleo primário global em 2010 foi usado para atender $94 \%$ da demanda total de energia de transporte. Os restantes $6 \%$ foram supridos por outras fontes, como os biocombustíveis, eletricidade, gás natural e outros. 
Figura 4: Consumo final de energia dos combustíveis por subsetor de transportes

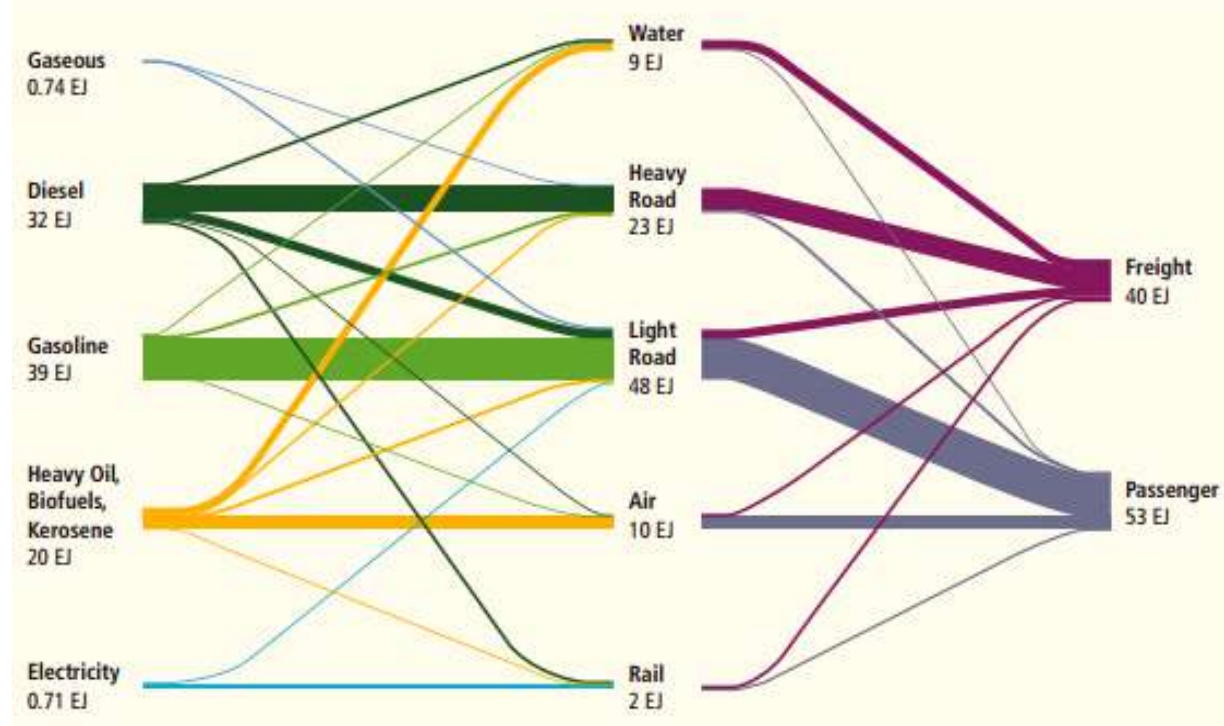

Fonte: IPCC (2014b)

A partir da figura anterior, pode-se concluir que o transporte de passageiro consome, no mundo, mais energia do que o transporte de cargas, representando respectivamente $55 \%$ e $45 \%$ da energia total do setor de transportes. Os gráficos 1 e 2 a seguir apresentam a estrutura modal de ambas categorias de transporte em diferentes países do mundo. Os dados de transporte de passageiros são apresentados na unidade de passageiro-quilômetro e os dados do transporte de cargas é expresso em toneladas-quilômetro. As unidades são definidas segundo Matos (2001) a seguir:

- 1 passageiro-quilômetro: significa um passageiro transportado por um quilômetro, independentemente do modal. Por exemplo, um carro transportando 2 passageiros por 4 quilômetros resultam em 8 passageiros-quilômetro, ou ainda, um ônibus transportando 5 passageiros por 3 quilômetros resultam em 15 passageiros-quilômetro.

- 1 tonelada-quilômetro: representa o movimento de uma tonelada de carga a uma distância de um quilômetro. A tonelada-quilômetro é calculada multiplicando-se o peso da carga transportada em toneladas de cada carregamento pelos quilômetros transportados. 


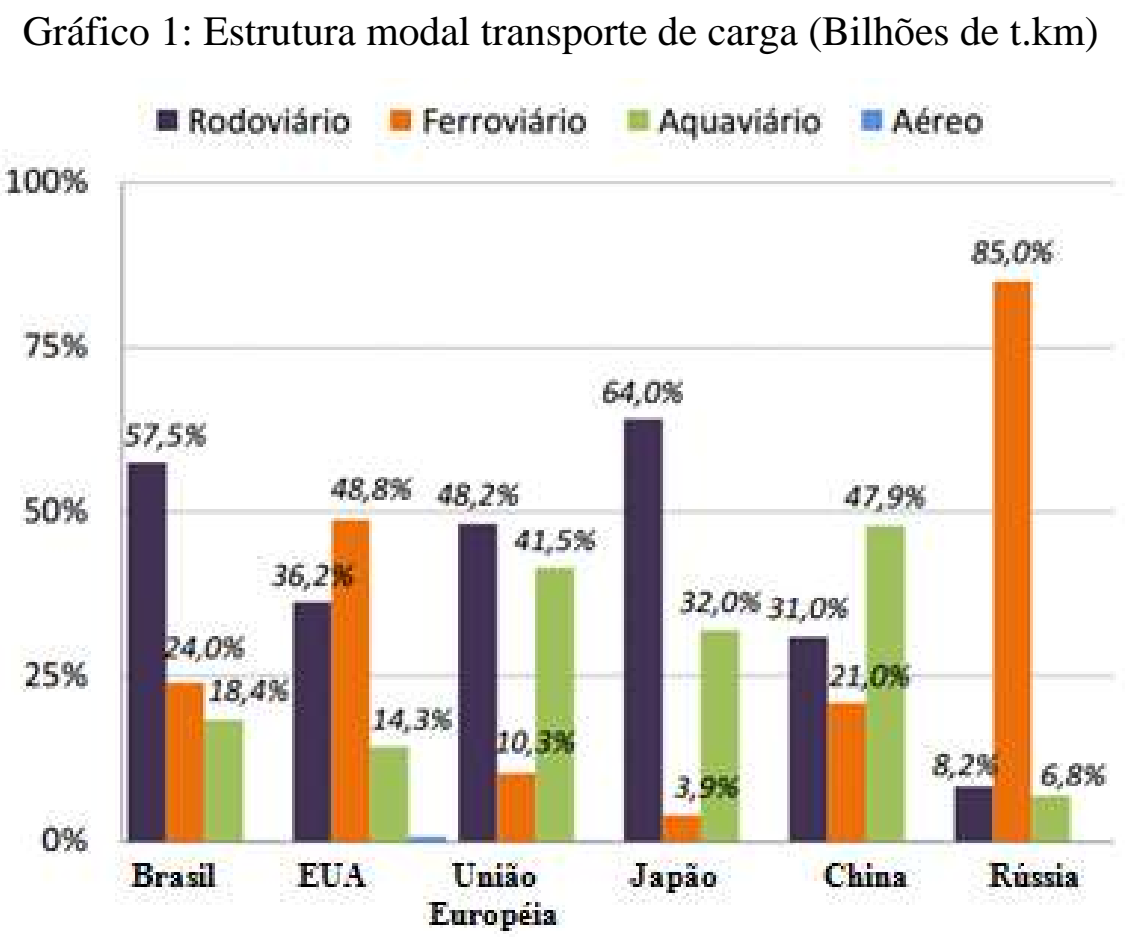

Fonte: Adaptado de Guerreiro (2012)

Conforme o gráfico anterior evidencia, o transporte de carga nos países analisados possui uma matriz de transporte relativamente heterogênea, apesar da elevada participação do modo rodoviário. Destaca-se a matriz de transporte da Rússia a qual realiza $85 \%$ do transporte de carga através do modo ferroviário. Com base nos países analisados, pode-se afirmar que, em média, aproximadamente, $41 \%$ do transporte de carga são realizados pelo modo rodoviário, $32 \%$ pelo modo ferroviário, e $26 \%$ pelo modo aquaviário, sendo que o modo aéreo representa menos de $1 \%$. 
Gráfico 2: Estrutura Modal - Transporte de Passageiros (bilhões de passageiros/km)

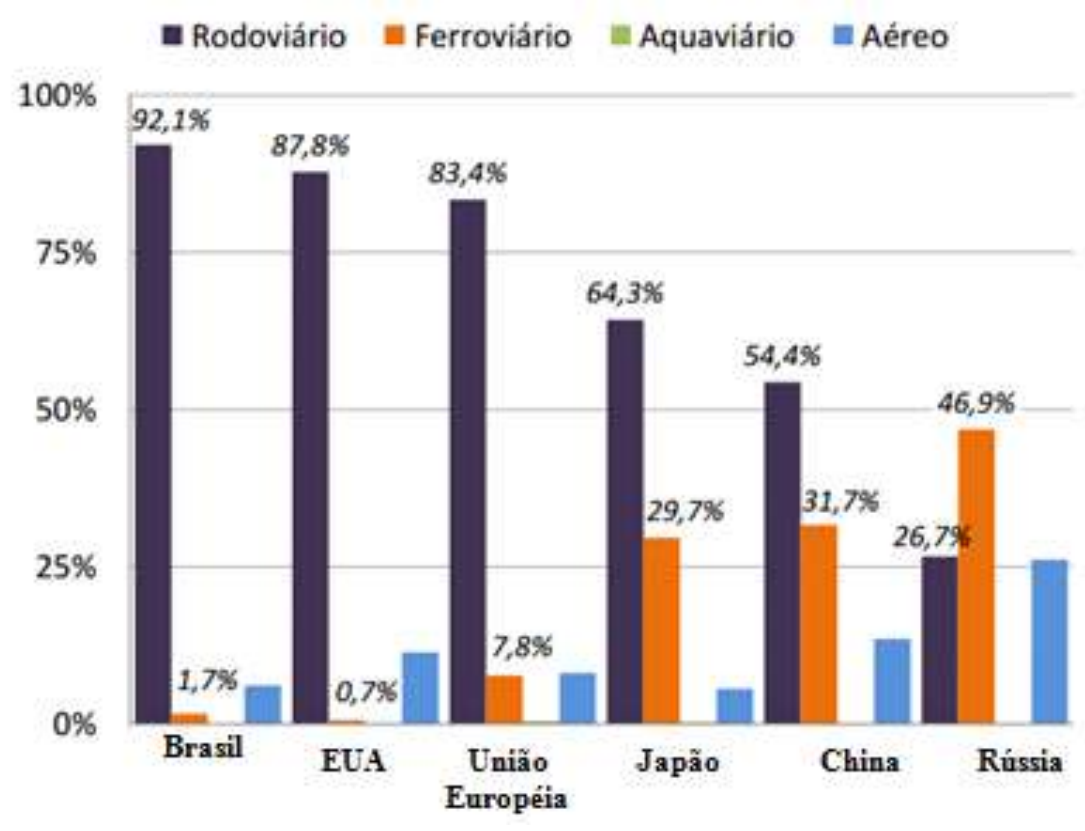

Fonte: Adaptado de Guerreiro (2012)

No tocante à participação dos diferentes modais no transporte de passageiros, percebese que em cinco das seis regiões analisadas no estudo, mais da metade do serviço é realizada pelo modo rodoviário. Destaca-se que apenas a China e a Rússia possuem uma matriz de transporte de passageiro mais heterogênea, onde o segundo modo de transporte mais utilizado é o ferroviário. Cabe ressaltar que a predominância do modo rodoviário aumenta o impacto ambiental do setor de transporte, tendo em vista que esse é o modo de transporte com maior consumo de energia.

\subsubsection{Emissões de GEE no transporte das cidades brasileiras}

Como não foi encontrada nenhuma estatística que reunisse dados detalhados de modos de transporte utilizados para todas as cidades brasileiras, foram escolhidas para análise as cidades do Rio de Janeiro, São Paulo, Belo Horizonte e Recife, devido principalmente à disponibilidade e facilidade de acesso aos inventários de emissões de gases de efeito estufa. Os inventários apresentam diferentes metodologias e formas de apresentação, por isto as análises destes não seguem um padrão determinado.

\subsection{1. a Emissões de transporte do Rio de Janeiro}

O inventário utilizado como fonte de dados foi realizado pela prefeitura do Rio de Janeiro em parceria com a COPPE/UFRJ publicado no ano de 2011. Esse estudo realizou 
algumas adaptações metodológicas, duas delas relacionadas ao setor de transportes. A primeira refere-se ao consumo do álcool combustível. Apesar de este combustível ser considerado “emissão zero", o inventário considera que no ciclo de produção do álcool anidro e hidratado existe emissão e esta deve ser assumida pelos seus consumidores. A outra adaptação é referente à importância socioeconômica da cidade do Rio de Janeiro, que atrai diariamente habitantes de outros municípios. Neste caso, o estudo considerou no cálculo das emissões todo o consumo comercializado dentro do município, independente da origem do veículo (Rio de Janeiro, 2011).

Dado o escopo desta dissertação, a análise do inventário se concentra nas emissões do setor de transportes, que é tratado no inventário dentro do setor de energia. As emissões do setor de energia no município do Rio de Janeiro somam 8.348,8 $\mathrm{Gg} \mathrm{CO}_{2 \mathrm{eq}}$. O setor de transportes responde por $66 \%$ dessas emissões, das quais $53 \%$ são provenientes do modo rodoviário (figura $5)$.

Figura 5: Emissões de GEE do setor de Energia por subsetor no município do RJ (Gg CO2eq)

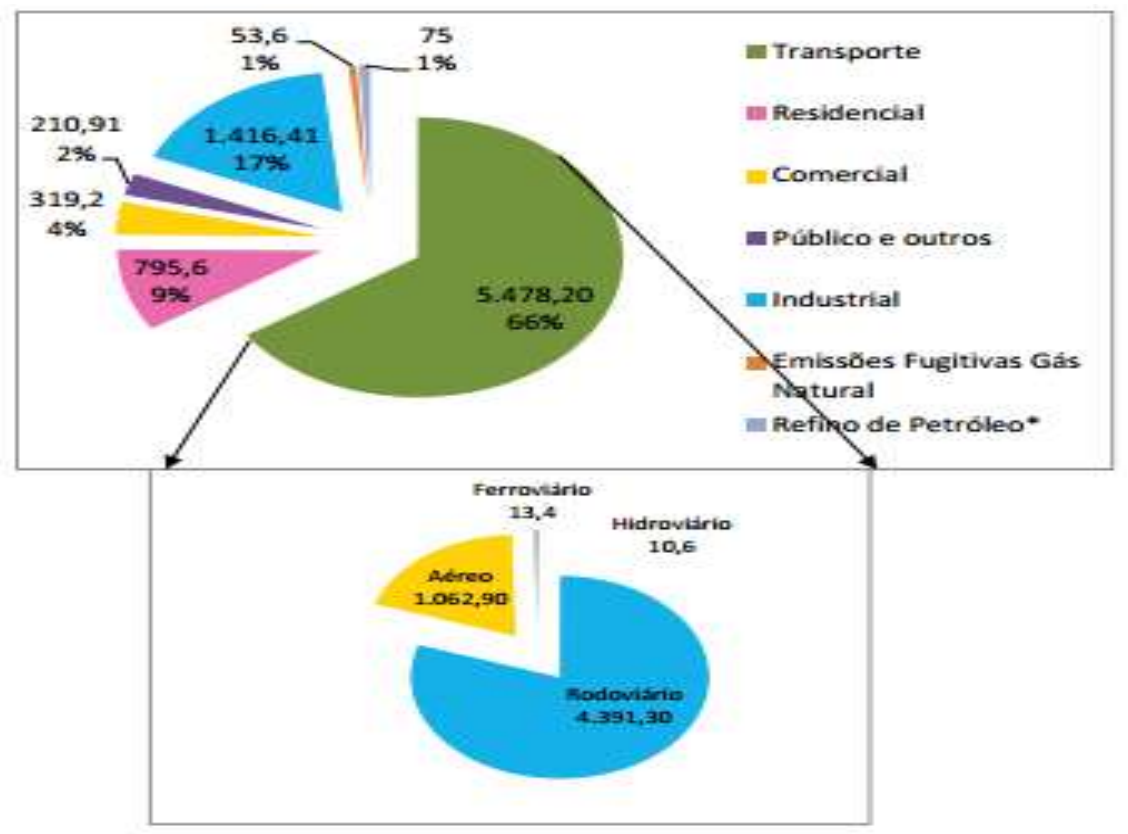

Fonte: Rio de Janeiro, 2011 
Tabela 7: Emissões em CO2eq nos Setores Socioeconômicos - Energéticos do Setor de Transportes

Gás Óleo Óleo Gasolina Queros. Eletric Álcool Natural Diesel Comb.

Aviação (anidro e Total hidratado)

\begin{tabular}{|c|c|c|c|c|c|c|c|c|}
\hline $\begin{array}{l}\text { Transporte } \\
\text { Total }\end{array}$ & $1.389,1$ & $1.427,6$ & 0,2 & $1.459,2$ & $1.060,64$ & 13,4 & 125,9 & 5.478 \\
\hline Rodoviário & $1.389,1$ & $1.417,2$ & - & $1.459,2$ & - & - & 125,9 & 4.391 \\
\hline Aéreo & - & - & - & - & $1.060,64$ & - & - & 1.063 \\
\hline Ferroviário & - & - & - & - & - & 13,4 & - & 13,4 \\
\hline Hidroviário & - & 10,4 & 0,2 & - & - & - & - & 10,6 \\
\hline $\begin{array}{l}\text { Residencial e } \\
\text { Comercial * }\end{array}$ & 257,4 & 3,9 & - & - & - & 427,6 & & 1.115 \\
\hline $\begin{array}{l}\text { Público e } \\
\text { outros* }\end{array}$ & 12,7 & 36,53 & 0,2 & - & & 98,2 & - & 211 \\
\hline Industrial* & $1.246,2$ & 46,63 & 10,2 & - & - & 100,8 & - & 1416 \\
\hline
\end{tabular}

Fonte: Rio de Janeiro, 2011

A tabela a seguir consolida as emissões de gases de efeito estufa do setor de transporte por modo no município do Rio de Janeiro em 2005. Pode-se observar que as emissões do modo rodoviário representam $80 \%$ do total de $\mathrm{GgCO}_{2 \mathrm{eq}}$ emitido pelo subsetor dos transportes e aproximadamente $53 \%$ do total de $\mathrm{GgCO}_{2 \text { eq }}$ emitido pelo setor de energia na cidade do Rio de Janeiro. 
Tabela 8: Emissões totais de GEE - setor de energia e transportes do Município do Rio de Janeiro (2005)

\begin{tabular}{ccccc} 
& $\mathrm{GgCO} 2$ & $\mathrm{tCH}_{4}$ & $\mathrm{tN}_{2} \mathrm{O}$ & $\mathrm{GgCO}_{2 \mathrm{eq}}$ \\
\cline { 2 - 5 } $\begin{array}{c}\text { Energia } \\
\text { Total }\end{array}$ & $8.242,9$ & $5.480,6$ & 344,9 & $8.348,9$ \\
\hline $\begin{array}{c}\text { Transporte } \\
\text { Total }\end{array}$ & $5.312,8$ & $2.883,7$ & 338,2 & $5.478,2$ \\
\hline Rodoviário & $4.235,4$ & $2.875,2$ & 308,1 & $4.391,3$ \\
\hline Aéreo & $1.053,5$ & 7,4 & 29,8 & $1.062,9$ \\
\hline Ferroviário & 13,4 & 0,1 & - & 13,4 \\
\hline Hidroviário & 10,5 & 1 & 0,3 & 10,6 \\
\hline
\end{tabular}

Fonte: Rio de Janeiro, 2011

\subsection{1.b Emissões de transporte da cidade de São Paulo}

Os dados das emissões de transporte do município de São Paulo foram retirados do inventário de emissões e remoções antrópicas do município publicado em 2013. O inventário segue a metodologia proposta pelo IPCC para inventários nacionais e está dividido em setores principais: resíduos; agricultura, florestas e outros usos da terra (AFOLU); energia, processos industriais e uso de produtos. Assim como no caso do inventário do município do Rio de Janeiro, a análise foca no sistema de transporte, alocado dentro do setor de energia.

As emissões do setor de energia representam $82 \%$ das emissões totais de gases de efeito estufa da cidade. As emissões energéticas são analisadas pelo inventário por duas perspectivas distintas: emissões fugitivas, que respondem por $0,5 \%$ das emissões, e a queima de combustível, que é responsável por $99,5 \%$ do total emitido. Dentro do subsetor de queima de combustíveis fosseis, os transportes respondem por $75 \%$ delas.

A tabela 9 apresenta as emissões dos gases de efeito estufa em toneladas de $\mathrm{CO}_{2 \text { eq }}$ para os anos de 2005 a 2009. Observa-se o crescimento das emissões do etanol hidratado e a queda significativa das emissões oriundas do querosene de aviação. As emissões de gasolina comum em 2009 tiveram uma queda simbólica em relação ao dado base. Ressalta-se que as emissões de $\mathrm{CO}_{2 \text { eq }}$ dos biocombustíveis não foram contabilizados por este inventário. 
Tabela 9: Emissões totais de GEE da categoria de transporte em CO2eq nos anos de 2005 a 2009 - Município de SP

$20052006 \quad \begin{gathered}2007 \\ \left(\mathrm{tCO}_{2 \mathrm{eq}}\right)\end{gathered} \quad 2008 \quad 2009$

\begin{tabular}{cccccc} 
Gasolina C & 3.981 .680 & 4.061 .989 & 4.049 .536 & 3.913 .147 & 3.686 .704 \\
\hline Etanol Hidratado & 31.198 & 56.028 & 86.669 & 107.618 & 133.333 \\
\hline Diesel & 3.856 .125 & 3.432 .238 & 3.968 .220 & 4.432 .085 & 4.289 .248 \\
\hline GNV & 536.344 & 640.291 & 700.261 & 618.698 & 417.943 \\
\hline $\begin{array}{c}\text { Gasolina de Aviação } \\
\text { Querosene de } \\
\text { Aviação }\end{array}$ & 22.916 & 24.271 & 5.330 & 5.457 & 5.454 \\
\hline Total & 861.408 & 963.896 & 968.979 & 745.040 & 712.036 \\
\hline & 9.289 .670 & 9.178 .713 & 9.778 .994 & 9.822 .045 & 9.238 .719 \\
\hline
\end{tabular}

Fonte: Elaborado com base em São Paulo (2012)

Ressalta-se que devido à falta de dados detalhados, as emissões da categoria de transportes são apresentadas somente para os modos rodoviário e aeroviário. Os combustíveis dos modos ferroviários e hidroviários foram incorporados no modo rodoviário e contabilizados conforme o fator de emissão dos mesmos. Os combustíveis contabilizados por cada um dos modos estão detalhados a seguir:

- Transporte rodoviário: Gasolina, Etanol, Diesel e Gás natural e veicular

- Transporte aéreo: Querosene de aviação e gasolina de aviação 
Tabela 10: Emissões do Município de SP contabilizadas em transporte aéreo e rodoviário nos anos de 2005 a 2009 - Município de SP

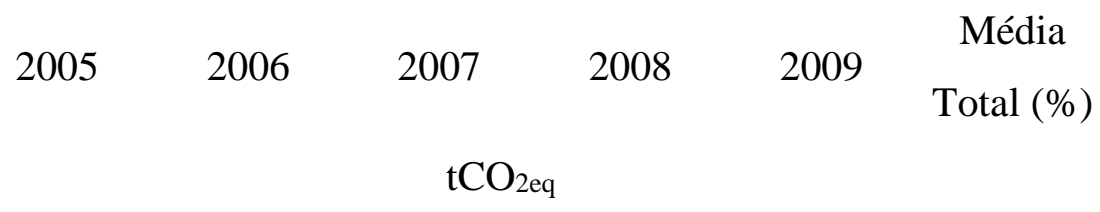

\begin{tabular}{ccccccc} 
& \multicolumn{6}{c}{$\mathrm{COO}_{2 \mathrm{eq}}$} \\
\cline { 2 - 6 } $\begin{array}{c}\text { Transporte } \\
\text { rodoviário }\end{array}$ & 8.405 .347 & 8.190 .546 & 8.804 .686 & 9.071 .548 & 8.527 .228 & 91 \\
\hline Transporte aéreo & 884.324 & 988.167 & 974.309 & 750.497 & 717.490 & 9 \\
\hline
\end{tabular}

Fonte: Elaborado com base em São Paulo (2012)

A tabela anterior foi calculada com base no total das emissões de gases de efeito estufa apresentadas na tabela 7, com o objetivo de ressaltar a importância do transporte rodoviário no município de São Paulo. Ressalta-se que estes dados apresentam apenas uma estimativa da parcela de cada um destes setores, visto que o transporte rodoviário contabiliza também as emissões dos modos ferroviários e hidroviários.

\subsection{1.c Emissões de Transporte em Belo Horizonte}

Os dados utilizados para a análise das emissões do setor de transporte de Belo Horizonte foram retirados da terceira atualização do inventário de emissões de gases de efeito estufa da cidade que compreendeu o período de 2011 e 2013. Os grupos de emissão por setor apresentados no inventário são divididos em:

- Unidades estacionárias: emissões residenciais, comerciais/ institucionais e geração de energia.

- Unidades móveis: emissões por modo de transporte rodoviário, ferroviário e aeroviário.

- Setor de resíduos: emissões por disposição de resíduos em aterro sanitário, tratamento biológico de resíduos e tratamento/lançamento de efluentes.

O inventário aponta que as emissões de GEE no município passaram de 2,59 milhões de toneladas de $\mathrm{CO}_{2 \text { eq }}$ em 2000 para 4,40 milhões de toneladas de $\mathrm{CO}_{2 \text { eq }}$ em 2013. Do total de emissões no ano de 2013, 71\% foi emitido pelo setor de transporte. A figura 6 apresenta graficamente as emissões do município por modo de transporte, onde destaca-se a participação 
de $75 \%$ das emissões proveniente do modo rodoviário. As emissões do modo ferroviário não são consideradas no inventário pois não puderam ser claramente desagregados de outras fontes.

Figura 6: Emissões das Unidades Móveis - Detalhamento por modal

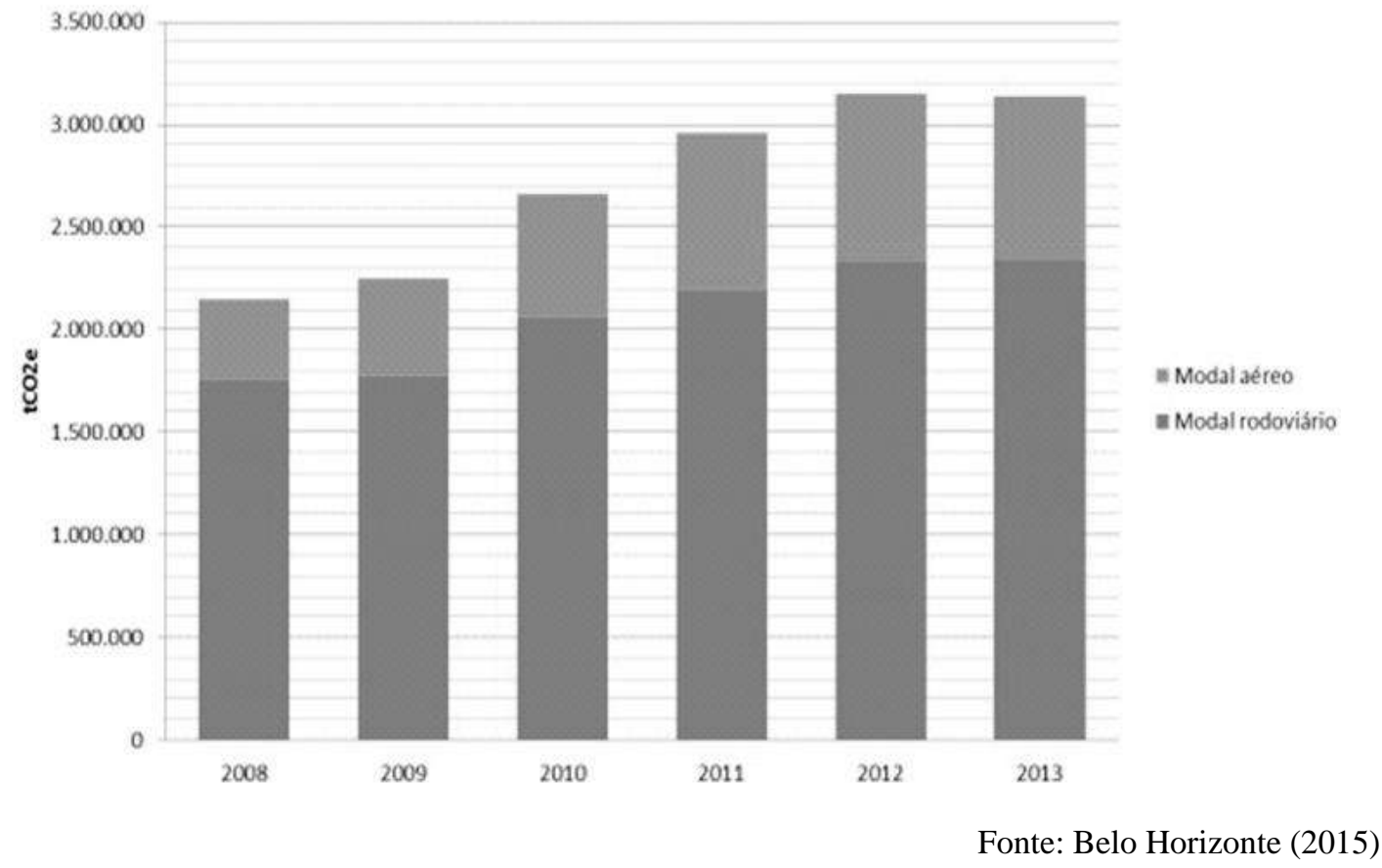

Com base na relevante participação do setor de transporte nas emissões totais e do modo rodoviário dentro destas, não é de se surpreender que o setor de unidades móveis se apresente entre os maiores emissores de GEE na cidade. Segundo o documento, os três maiores percursores dessas emissões são a gasolina automotiva, o óleo diesel e o querosene de aviação. Juntos, estes três representaram 75\% do total emitido pelo município no ano de 2013.

O inventário aponta dentre os três, a participação expressiva da gasolina automotiva, que representava 59\% do total de emissões da cidade em 2013. O segundo principal contribuinte a partir de 2011, foi o querosene de aviação, que apresentou um crescimento expressivo desde 2008. O óleo diesel, utilizado principalmente na forma rodoviária (82\%) apresentou uma redução nas emissões desde 2011 e é atualmente o terceiro maior percursor das emissões de gases de efeito estufa. A figura 7 apresenta graficamente as emissões do município por matriz energética do sistema de transporte. 
Figura 7: Matriz energética do sistema de transportes em Belo Horizonte, 2008 a 2013

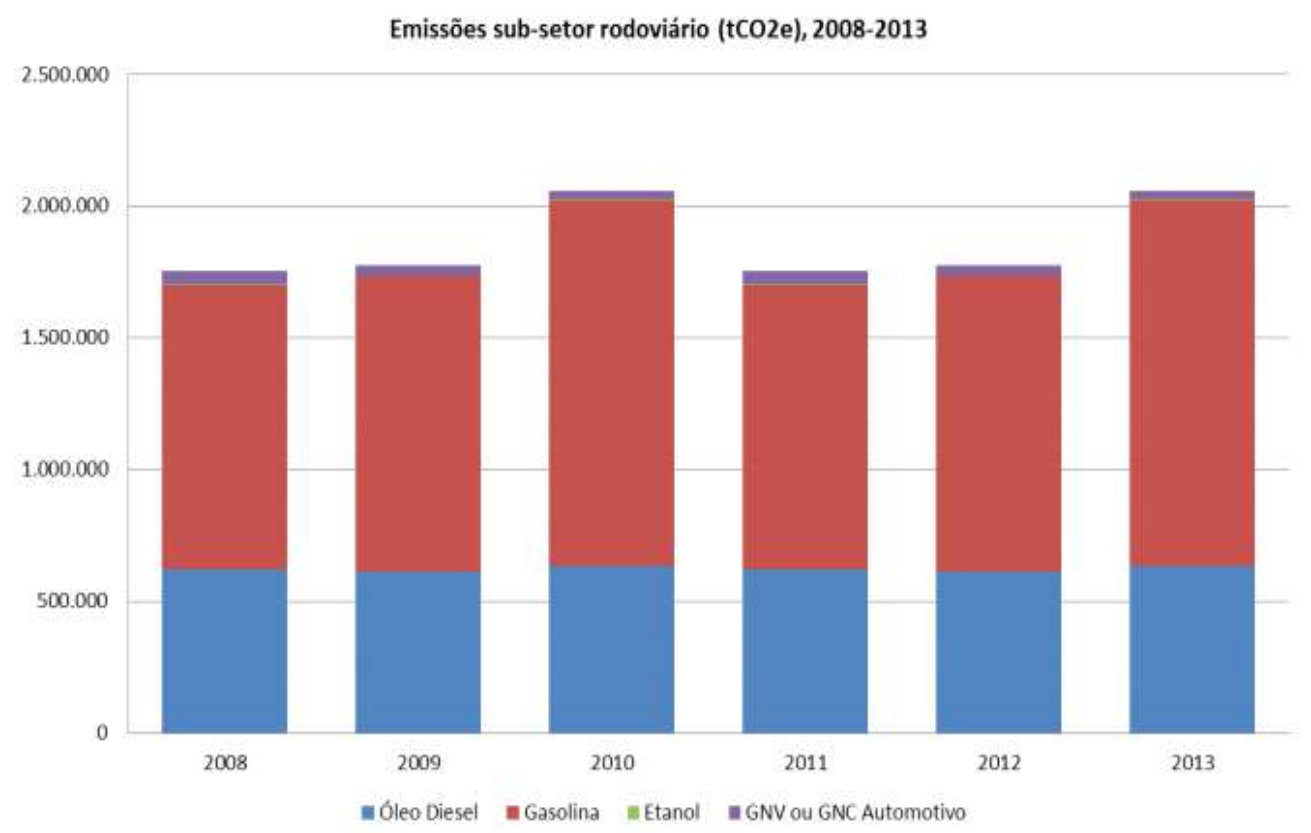

Fonte: Belo Horizonte (2015)

De acordo com o inventário, as emissões do modo rodoviário cresceram amparadas pela gasolina, uma vez que o etanol teve sua participação reduzida devido à elevação dos preços. Desta forma, o documento reconhece um movimento intenso iniciado em 2009 que substituiu o uso do etanol pela gasolina. Segundo o inventário, ainda que a produção de veículos flex no Brasil tenha alcançado cerca de $80 \%$ de todos os novos veículos, a preferência pela gasolina na frota em 2013 era de $71 \%$ o que agrava a perspectiva das emissões futuras.

\subsection{1. d Emissões de Transporte em Recife}

A cidade de Recife publicou seu primeiro inventário de emissões de gases de efeito estufa no ano de 2015 utilizando dados do ano de 2012. O inventário apresenta as emissões em três setores: unidades estacionárias (edifícios, equipamentos, iluminação pública, etc), transportes e resíduos.

As análises das emissões são dividas também no escopo do governo e da comunidade local. No caso do setor de transportes, no nível do governo são contabilizados os consumos dos seguintes itens: (i) transporte governamental - utilização da frota municipal; (ii) transporte de funcionários - utilização de modais de mobilidade para chegar ao trabalho ou compromissos. No escopo da comunidade, as emissões de GEE foram contabilizadas considerando as emissões das seguintes fontes: veículos rodoviários, transporte aéreo, marítimo e ferroviário. 
Segundo o documento, o setor de transportes é responsável pela emissão de 2.041.976 $\mathrm{tCO}_{2 \text { eq }}$ do qual apenas $0,15 \%$ refere-se as operações do governo municipal. Dentro dessas emissões, destaca-se a participação expressiva do transporte terrestre que responde por $69,3 \%$ do total das emissões, seguido do transporte aéreo com 30,6\% e a participação simbólica do modo hidroviário com $0,1 \%$.

Destaca-se a gasolina como principal combustível poluente responsável por 35,8\% das emissões do setor, seguido do querosene de aviação com 30,5\%, diesel com 27,7\%, etanol com $3 \%$ e o óleo combustível com $2,8 \%$. Os demais combustíveis correspondem a $0,1 \%$ do total de emissões. A figura a seguir apresenta essas emissões conforme o tipo de transporte e o combustível utilizado no escopo da comunidade.

Figura 8: Total de emissões (tCO2eq) em Recife por tipo de combustível

Fontes Móveis Comunidade tCO2e

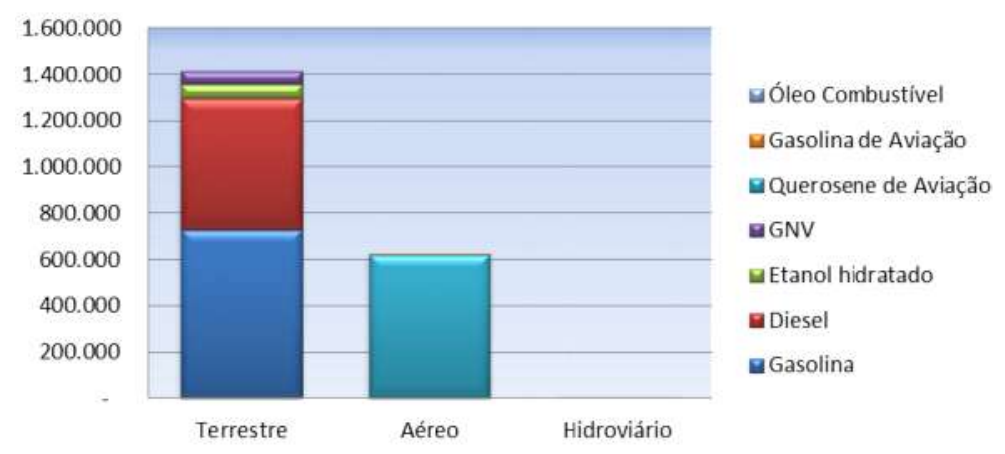

Fonte: Recife (2014)

\subsection{1.e Considerações finais acerca dos inventários de emissões municipais}

A participação das emissões do setor de transportes nas emissões urbanas municipais, como evidenciado a partir dos inventários anteriormente apresentados é essencialmente ligada ao modo de transporte rodoviário. As tabelas 11 e 12 resumem as participações do setor de transportes nas emissões municipais e do transporte rodoviário dentro dessas emissões. Ao comparar os municípios deve-se atentar a diferença nas metodologias entre os inventários. 
Tabela 11: Participação do setor de transporte nas emissões municipais de gases de efeito do setor de energia

\begin{tabular}{cc} 
Rio de Janeiro & 66 \\
\hline São Paulo & 75 \\
\hline Belo Horizonte & $71^{*}$ \\
\hline Recife & $65 *$ \\
próprio. Esta porcentagem representa as emissões do & \\
setor de transportes no total das emissões do município
\end{tabular}

Fonte: Elaboração Própria

Tabela 12: Participação do modo rodoviário nas nas emissões municipais de gases de efeito estufa do setor de transportes

\begin{tabular}{cc} 
Rio de Janeiro & 80 \\
\hline São Paulo & $91^{* *}$ \\
\hline Belo Horizonte & 75 \\
\hline Recife & 69 \\
\hline **Inclui as emissões dos modos ferroviários e
\end{tabular}

hidroviários

Fonte: Elaboração Própria

Esta seção mostrou que, além das cidades serem responsáveis pela maioria das emissões de GEE, o setor de transporte contribui de forma crucial para as mudanças climáticas (Santos, 2014). Neste sentido, considerando a tendência de crescimento urbano e a necessidade vital dos transportes para as atividades antrópicas nas cidades, a expectativa é que, caso o padrão mundial do sistema de transporte urbano não se altere, as emissões do setor se tornem cada vez mais expressivas (Vasconcellos, 2006).

A crescente urbanização e o aumento da demanda por transportes implacarão no aumento significativo do impacto do setor de transportes no aquecimento global. Além do crescimento das emissões de gases de efeito estufa do setor, crescerá também o impacto proveniente de sua infraestrutura urbana. Conforme aponta o IPCC (2014a), o crescimento dos espaços urbanos provoca um aumento na demanda pela infraestrutura urbana, que impacta diretamente o aquecimento global. Parte deste impacto ocorre devido à diminuição do potencial 
da superfície terrestre em refletir radiação, aquecendo a temperatura na superfície terrestre. A seção a seguir aborda o impacto da infraestrutura urbana de transportes no aquecimento global através do seu potencial de refletir radiação.

\subsection{Infraestrutura urbana de transportes e aquecimento global}

O Forçamento Radiativo associado ao uso e cobertura da superfície desde a era préindustrial até os dias atuais é de $-0.2+-0.2 \mathrm{Wm}^{-2}$. Destacam-se as duas principais atividades antrópicas que alteram diretamente o albedo da superfície ${ }^{5}$ : o desmatamento, que conforme explicado aumenta o potencial de reflexão da terra e a urbanização, que pelo aumento de superfícies escuras, provoca, ao contrário, a diminuição do albedo terrestre. Atualmente, o impacto da alteração do albedo da superfície terrestre está caracterizado como uma forçante radiativa negativa. No entanto, esse potencial de reflexão está cada vez menor. No tocante a participação direta das atividades antrópicas, a literatura internacional reconhece o crescimento contínuo dos centros urbanos como uma das principais fontes de impacto (Akbari et al, 2009).

De acordo com Akbari et al (2008), as áreas urbanas ocupam 1,2\% da superfície terrestre e são habitadas por 3 milhões de pessoas ${ }^{6}$. Nesta linha, a tendência de crescimento urbano de 6 bilhões moradores em centros urbanos (ONU,2014), resultaria na duplicação do espaço atualmente ocupado pelas cidades na superfície terrestre. Ainda que esta porcentagem pareça simbólica em relação ao todo, ressalta-se que os continentes ocupam $21 \%$ da superfície terrestre e isso inclui as áreas de rios, lagos, desertos, florestas, etc. Desta forma, o impacto da substituição de superfícies de áreas verdes para superfícies escuras, como telhados e a infraestrutura urbana de transportes (pavimentos) irá provocar um aumento na absorção de energia e consequentemente um desequilíbrio cada vez maior no balanço de radiação.

Atualmente, como aponta Akbari et al (2007), as áreas urbanas são constituídas em sua maioria (60\%) de área construída, onde os telhados representam em torno de $20-25 \%$ e as vias e pavimentos correspondem, em média, por $40 \%$. A tabela seguir apresenta alguns exemplos de ocupação das superfícies urbanas em algumas áreas metropolitanas dos EUA. Estas proporções deixam claro que o albedo das áreas urbanas é constituído principalmente de superfícies que possuem um baixo potencial de refletir a radiação recebida e, desta forma se caracterizam como espaços que retém maior quantidade de radiação. Tal fato é analisado

\footnotetext{
${ }^{5}$ Somam-se a estas, a diminuição do albedo terrestre provocado pelo derretimento das calotas polares, um dos efeitos do aquecimento global. Como este é apenas um impacto indireto da contribuição antrópica, sua importância aqui é secundária. ${ }^{6}$ Os autores calculam este percentual a partir de uma densidade urbana de $430 \mathrm{~m}^{2}$, baseado na densidade média das 100 maiores regiões metropolitanas do mundo.
} 
também por Menon et al (2010) que afirma que a alteração da cobertura da superfície por materiais de baixo albedo provoca muitas vezes um balanço de radiação da área urbana diferentes daquelas ao seu redor.

Tabela 13: Ocupação da área urbana em regiões metropolitanas - EUA Área

\begin{tabular}{ccccc}
$\begin{array}{c}\text { Área } \\
\text { Metropolitana }\end{array}$ & Vegetação & $\begin{array}{c}\text { Infraestrutura de transportes } \\
\text { (pavimentos) }\end{array}$ & Telhados & Outros \\
\hline Salt Lake City & 33,3 & 36,4 & 21,9 & 8,5 \\
\hline Sacramento & 20,3 & 44,5 & 19,7 & 15,4 \\
\hline Chicago & 26,7 & 37,1 & 24,8 & 11,4 \\
\hline Houston & 37,1 & 29,2 & 21,3 & 12,4 \\
\hline
\end{tabular}

Fonte: Rose (2003) apud Akbari (2008)

A atual forma de ocupação dos espaços urbanos, majoritariamente por superfícies escuras, somada as atuais tendências de urbanização, reflete a importância de reconhecer o impacto da alteração do albedo destas áreas no aquecimento global. Neste sentido, é crescente o número de estudos com modelos climáticos que avaliam a mudança no forçamento radiativo e na temperatura resultantes de alterações no albedo dos telhados e dos pavimentos das áreas urbanas. Akbari et. al (2007) cita alguns cientistas que já realizaram estudos nesta área, como Lenton e Vaughan (2009), que analisaram o efeito de diferentes técnicas de geoengenharia a partir do uso do solo urbano; Loveland et al (2000), que desenvolveram um banco de dados global com características de cobertura da superfície terrestre.

Na mesma linha, um estudo publicado por Oleson et al (2010) quantificou o efeito de telhados brancos na temperatura urbana; e Winton (2006) estimou o efeito do albedo na temperatura global. Outro estudo realizado por Saber et al (2011) afirma que edifícios e outras estruturas construídas são responsáveis por uma grande parte dos impactos globais e locais das alterações climáticas. Este estudo também apresenta alguns autores que reconhecem a importância de telhados verdes e mais refletivos para a redução de temperatura em áreas urbanas; por exemplo, Xu et al (2012); Solecki et al (2005) e Jo et al (2010). A tabela a seguir apresenta uma lista com os principais estudos que reconhecem a importância do albedo das cidades no aquecimento global. 
Tabela 14: Estudos sobre impacto da infraestrutura urbana e aquecimento global

\section{Infraestrutura}

transportes

Telhados

Ambos

(pavimentos)

\begin{tabular}{cc}
\hline Akbari et al (2001) & $\mathrm{x}$ \\
\hline Akbari et al (2003) & $\mathrm{x}$ \\
\hline Myhre e Myhre (2003) & $\mathrm{x}$ \\
\hline Kaarsber e Akbari (2006) & $\mathrm{x}$ \\
\hline Akbari et al (2007) & $\mathrm{x}$ \\
\hline Synnefa et al (2008) & $\mathrm{x}$ \\
\hline Campra et al (2008) & $\mathrm{x}$ \\
\hline Lenton e Vaughan (2009) & $\mathrm{x}$ \\
\hline Akbari et al (2009) & $\mathrm{x}$ \\
\hline Levinson e Akbari (2010) & $\mathrm{x}$ \\
\hline Akbari et al (2010) & $\mathrm{x}$ \\
\hline Menon et al (2010) & \\
\hline
\end{tabular}

Fonte: Elaboração própria com base nos autores citados

Ainda que não haja, dentro do referencial teórico analisado, material específico relacionado exclusivamente ao impacto da infraestrutura de transportes, esta ocupa a maior parte da área construída das cidades (Akbari et al, 2007). Segundo o relatório da UN-Habitat, as porcentagens da área das cidades destinadas às vias urbanas variam conforme o nível de desenvolvimento das mesmas. Ou seja, cidades em países mais desenvolvidos tendem a ter maior área ocupada pela infraestrutura do setor de transportes quando comparadas a cidades em países em desenvolvimento.

Nesta mesma linha, Vasconcellos (2006) aponta que em países em desenvolvimento a área destinada a vias nas cidades é em média $20 \%$ enquanto nos países desenvolvidos este número é ainda maior. Segundo o autor, cidades como Bangkok e São Paulo possuem 11,4\% e $21 \%$ respectivamente das áreas de vias nas cidades. No caso da cidade do Rio de Janeiro, 
como será apresentado no estudo de caso (Capítulo 4) a porcentagem de vias urbnanas é similar a aquelas dos países em desenvolvimento. Em contrapartida, em cidades como Paris e Tóquio, cidades desenvolvidas, as vias ocupam respectivamente $25 \%$ e $24 \%$ do espaço total das cidades.

Um relatório publicado pela UN-Habitat (2013) analisa as áreas alocadas para vias em 100 cidades de países desenvolvidos (Europa, América do Norte e Oceania) e em desenvolvimento (África, Ásia e América Latina), como mostram as figuras 9 e 10 respectivamente. Ressaltam-se alguns exemplos de cidades de países desenvolvidos como Barcelona - 33\%, Toronto- 29\%, Bruxelas - 26\%, e países em desenvolvimento como Guatemala- $13 \%$, Jakarta- 9,5\%, Singapura - 22\%. 
Figura 9: Área destinada a vias em cidades da Europa, América do Norte e Oceania FIGURE 3.1 LAND ALLOCATED TO STREET (LAS) IN CITIES, EUROPE, NORTH AMERICA \& OCEANIA

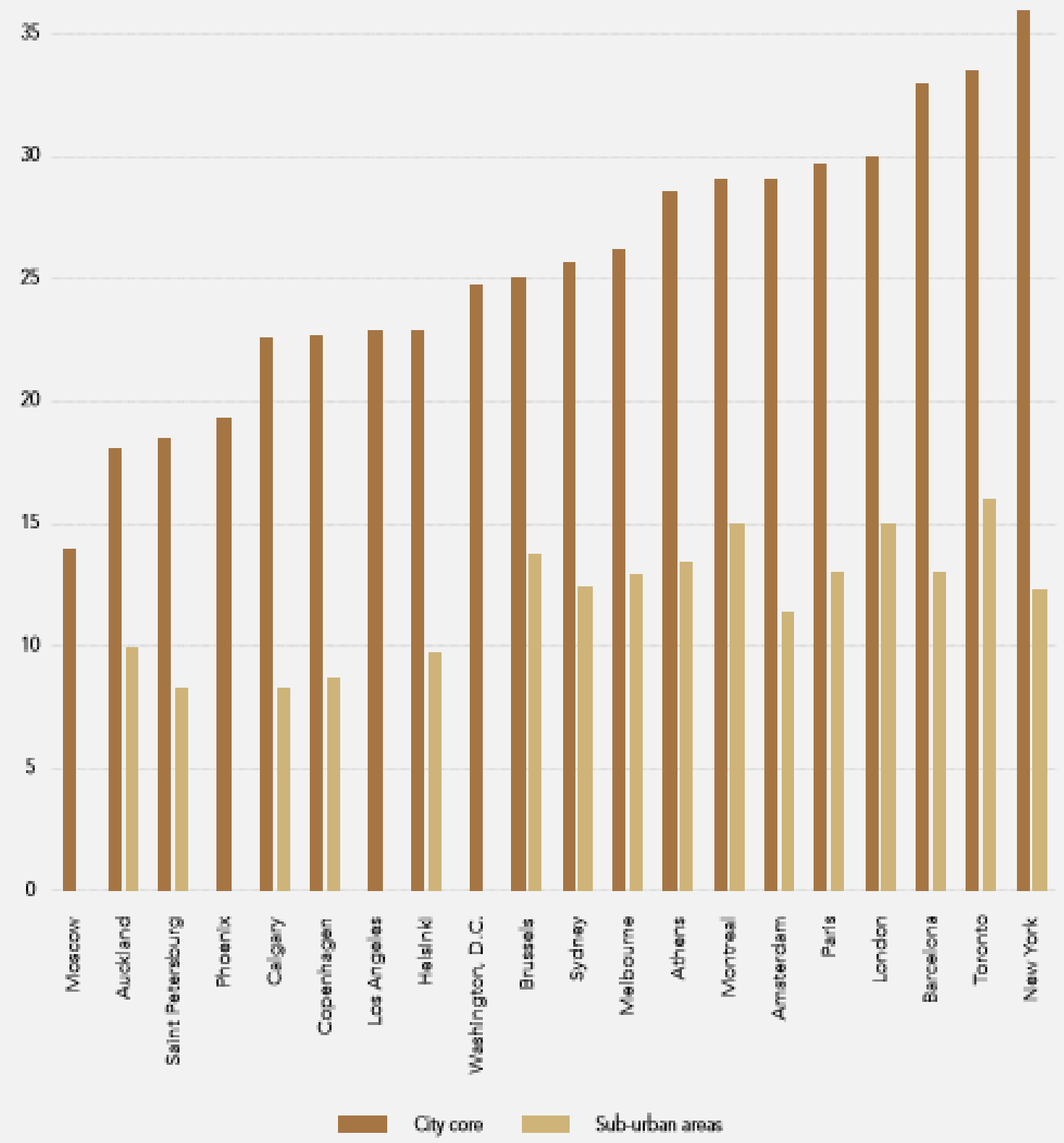

Fonte: UN-HABITAT (2013) 
Figura 10: Área destinada a vias em cidades da África, Ásia, América Latina e Caribe FIGURE 4.1 LAND ALLOCATED TO STREET (LAS) IN CITIES AFRICA, ASIA AND LATIN AMERICA AND THE CARIBBEAN

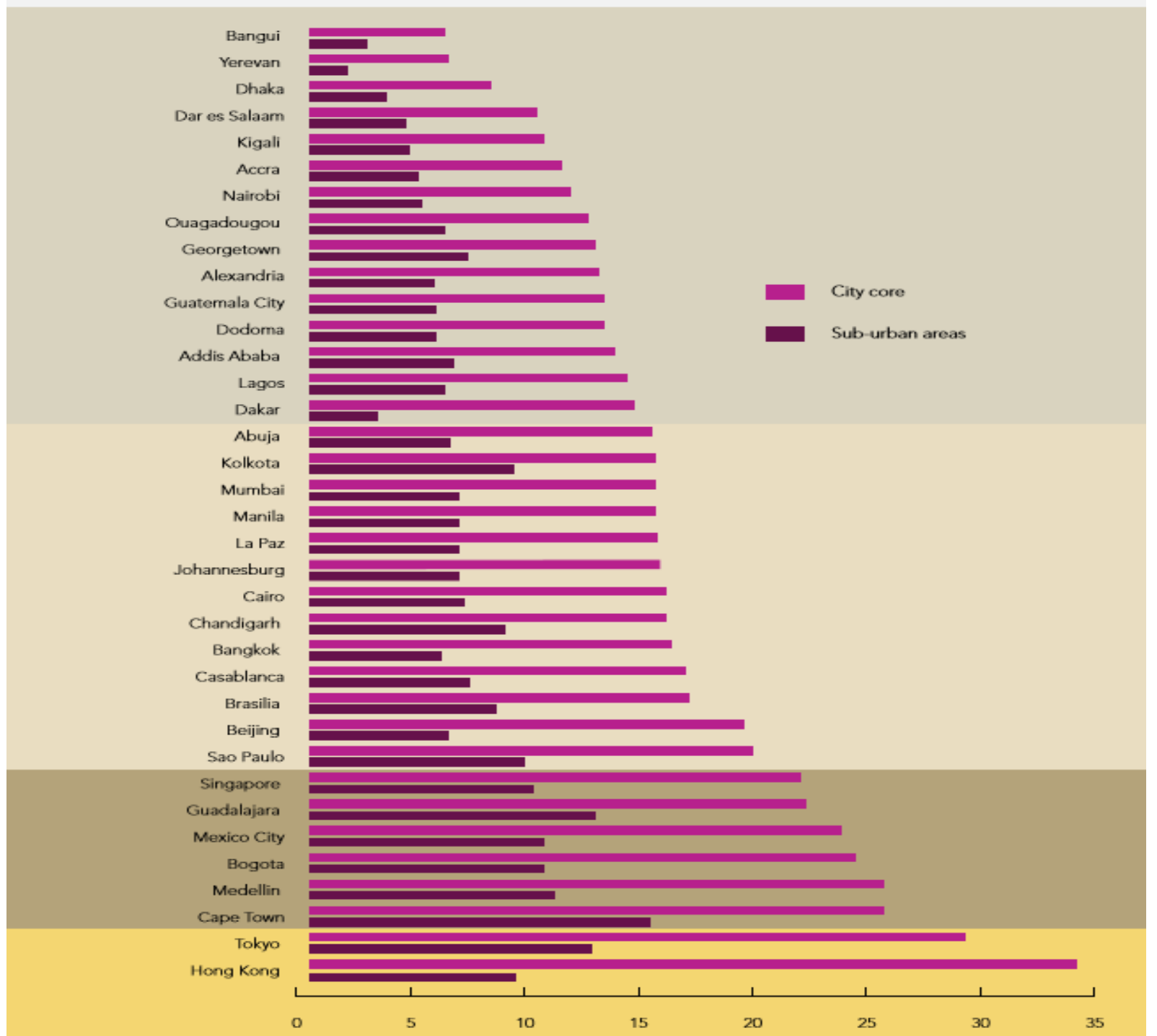

Fonte: UN-HABITAT (2013)

Segundo o relatório, a grande parcela de vias urbanas em cidades de países desenvolvidos, como aquelas da América do Norte e Oceania, é reflexo de um modelo de desenvolvimento urbano focado no transporte motorizado, essencialmente no automóvel. De acordo com Vasconcellos (2006), as externalidades negativas provenientes deste modelo de desenvolvimento são a principal fonte de impactos do sistema de transporte no espaço urbano. Pode-se entender por estes impactos, não só as emissões de gases de efeito estufa, como também o espaço urbano ocupado pela infraestrutura de transportes, visto que, o automóvel consome 30 vezes mais espaço viário que um ônibus, (Vasconcellos, 2006). Desta forma, ressalta-se a 
importância da transição para um padrão de desenvovimento em que haja um uso do espaço urbano por transportes mais eficientes e sustentáveis.

\subsubsection{Infraestrutura urbana de transportes e o uso do espaço viário}

A partir da Revolução Industrial o modo de transporte motorizado passou a ser o modal mais incentivado em diversos países do mundo, com destaque ao automóvel particular. Segundo Achante (2014), a evolução do automóvel como modal dominante no século XX é clara. Sua importância pode ser percebida ao analisar o crescimento do número de registros de veículos entre 1960 e 2000 . Este número aumentou aproximadamente cinco vezes, saltando de 98 milhões em 1960 para 549 milhões de veículos em 2000 (Boundy; Davis; Diegel, 2011). As previsões indicam que esses ainda serão os responsáveis por mais de $60 \%$ do tráfego motorizado (motocicletas, automóveis, ônibus, trens e metros) mundial na primeira metade do século XXI (WBCD, 2004).

A dependência do modo rodoviário no mundo pode ser observada no gráfico 3 a seguir. O gráfico mostra que mais de $85 \%$ do transporte urbano e interurbano de passageiros foi realizado por automóveis ou ônibus. No caso das cidades brasileiras com mais de 60 mil habitantes, o transporte rodoviário também predomina na divisão modal das viagens urbanas e interurbanas, respondendo por $87,5 \%$ destas. Dentro desta divisão, observa-se também a predominância do transporte particular como maioria, respondendo por $54,2 \%$ das viagens no mundo e 45,6\% no Brasil (D’agosto, 2015).

Gráfico 3: Divisão modal no mundo

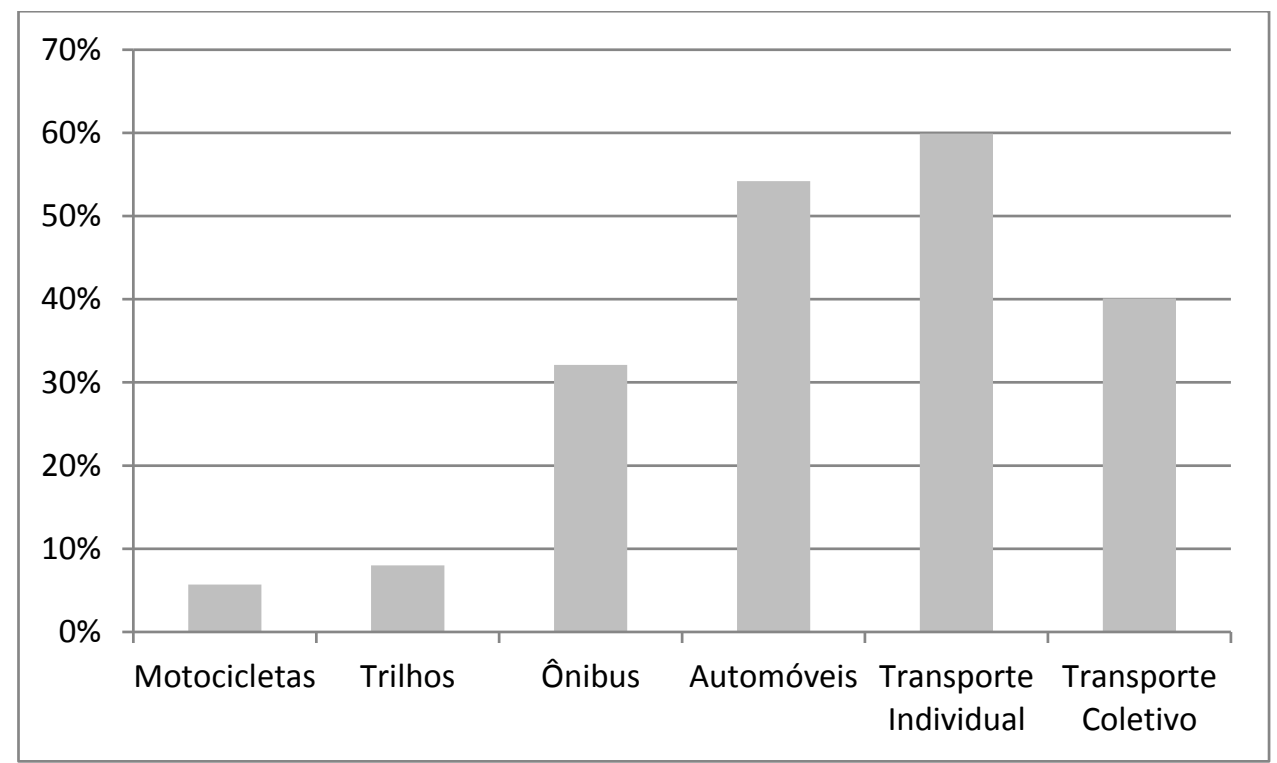


Sendo assim, como pode ser evidenciado pela parcela de vias nas cidades apresentada anteriormente e pelo total de viagens realizado pelo modo rodoviário, pode-se assumir que a infraestrutura urbana de transportes é destinada quase em sua totalidade ao modo rodoviário e mais especificamente ao automóvel. Tal fato acarreta uma ineficiência na ocupação do espaço público (D’agosto, 2015). Segundo Vasconcellos (2006), o espaço per capita de via ocupado varia de acordo com o modo de transporte, sua velocidade e o tempo que permanece parado. $\mathrm{O}$ gráfico 4 apresenta o uso de espaço público para transporte por passageiros em uma faixa de $3,5 \mathrm{~m}$ de largura por hora, onde destacam-se como mais eficientes o transporte por trens e a pé.

Gráfico 4: Uso do espaço público para transporte de passageiros por modo de transporte

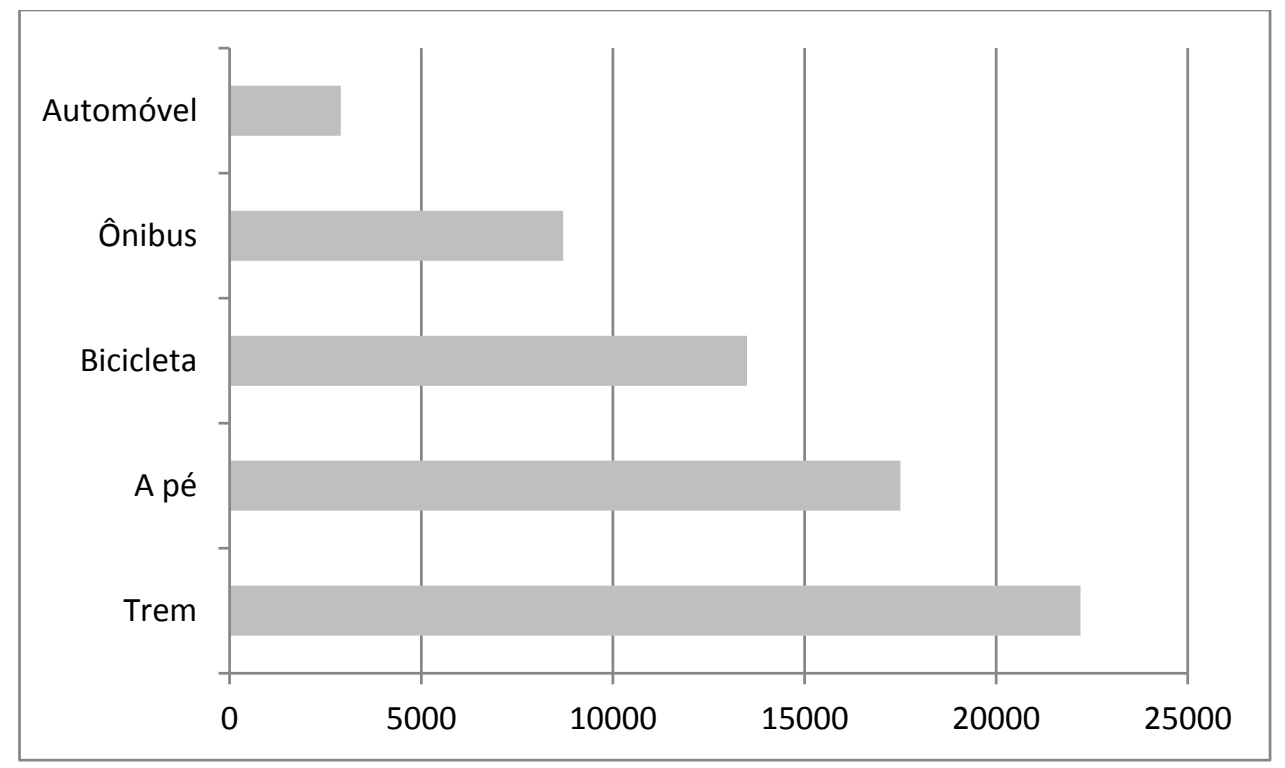

Fonte: Adaptado de D`Agosto (2015)

Como pode ser observado no gráfico anterior, o automóvel é o modo de transporte urbano mais ineficiente e ainda assim o mais incentivado. De acordo Vasconcellos (2006), uma das características negativas do automóvel é que eles permanecem parados entre 20 a 22 horas por dia e por isso demandam ainda mais infraestrutura. Desta forma, como aponta o autor, em várias cidades brasileiras as pessoas que utilizam automóveis ocupam cerca de 70 a $80 \%$ do espaço viário, podendo até, no caso de Brasília atingir 90\% da área total (ver tabela 15). Vasconcellos (2006) aponta que no caso dos automóveis, cada passageiro chega a ocupar quase oito vezes mais espaço em uma via pública que os passageiros de ônibus (Tabela 16). 
Tabela 15: Espaço viário usado pelas pessoas em ônibus e em carros, várias cidades brasileiras (1998)

\begin{tabular}{lll}
\multirow{2}{*}{ Cidade } & \multicolumn{2}{l}{ Área de via usada $(\%)$} \\
\cline { 2 - 3 } & Autos & Ônibus \\
\hline Porto Alegre & 69,6 & 30,3 \\
\hline Rio de Janeiro & 74,3 & 25,6 \\
\hline Belo Horizonte & 77,2 & 22,7 \\
\hline Curitiba & 79,2 & 20,7 \\
\hline Recife & 84,5 & 15,4 \\
\hline Campinas & 87,1 & 12,8 \\
\hline João Pessoa & 87,7 & 12,2 \\
\hline São Paulo & 88 & 11,9 \\
\hline Brasília & 90,7 & 9,7 \\
\hline
\end{tabular}

Fonte: Vasconcellos (2006)

Tabela 16: Espaço ocupado na via pelos modos de transporte no espaço urbano Automóvel Motocicleta

Ônibus

\begin{tabular}{cccc}
\hline Espaço na via1 & $21 \mathrm{~m}^{2}$ & $8 \mathrm{~m}^{2}$ & $54 \mathrm{~m}^{2}$ \\
\hline Lotação média & 1,5 & 1,1 & 30 \\
& passageiros & passageiros & passageiros \\
\hline Espaço per capita & $14,0 \mathrm{~m}^{2}$ & $7,3 \mathrm{~m}^{2}$ & $1,8 \mathrm{~m}^{2}$ \\
\hline $\begin{array}{c}\text { Proporção vs. } \\
\text { Ônibus }\end{array}$ & 7,8 & 4 & 1 \\
\hline
\end{tabular}

1 inclui o espaço total necessário para a circulação do veículo Fonte: Gomide e Morato (2011)

O uso do espaço público destinado à infraestrutura de transporte do modo rodoviário principalmente o automóvel - aprisiona as cidades em um modelo ineficiente de 
desenvolvimento urbano, dependente da construção de vias e estacionamentos. Isto porque, gera-se um ciclo vicioso, onde o aumento das vias e estacionamentos como solução para os atuais problemas de mobilidade urbana estimula o uso do automóvel nas cidades. Tal ciclo ocorre, pois, como aponta o BID (2013), o aumento das vias e estacionamentos diminuem, principalmente no caso do automóvel, o tempo total da viagem e o custo total de deslocamento. Esta diminuição no tempo e custo de viagem incentiva o automóvel como meio de transporte, que provoca novamente o aumento da necessidade por infraestrutura.

Dentro desta análise observa-se, por exemplo, a ampla área da cidade planejada para estacionamentos no caso da Cidade do México, conforme um estudo publicado pelo Instituto de Políticas de Transporte e Desenvolvimento (ITDP, sigla em inglês) em 2014 (ITDP, 2014). O trabalho chama a atenção para o crescimento exponencial das áreas urbanas ocupadas por estacionamentos a partir de 2009. Segundo o relatório, o número de vagas cresceu em média $33 \%$ no período de 2009 a 2013, onde o número passou de 80.874 para 250.344 . A expansão das áreas urbanas projetada entre 2009 e 2013 destina mais espaço a estacionamentos (42\%) do que à habitação (32\%) (ITDP, 2014).

O caso da cidade do México reportado neste relatório pode ser tido como exemplo dos modelos de desenvolvimento urbano que caracterizam as cidades atualmente. Tal fato é resultado de uma falta de planejamento urbano adequado e de políticas de transporte que já deveriam ter sido deixadas para trás. Em consequência, diversas cidades enfretam um conflito entre satisfazer a procura por mais estacionamentos e espaço viário e a necessidade de controlar os consequentes impactos negativos, inclusive aqueles provenientes de sua infraestrutura.

Desta forma, considerando os modelos de previsão de crescimento das cidades, tornase fundamental romper certos paradigmas dos padrões de construção e urbanização comumente adotados nas cidades (EMBARQ, 2014). Reconhecendo o impacto da sua infraestrutura de transportes (as vias e pavimentos) até aqui apresentado, a seção a seguir apresenta possíveis medidas de mitigação relacionadas ao impacto da destas superfícies no aquecimento global.

\subsubsection{Políticas de mitigação ao impacto da infraestrutura urbana de transportes} no aquecimento global

As políticas de mitigação da infraestrutura de transportes urbana que aqui são apresentadas abordam o impacto desta no aquecimento global a partir de duas fontes principais: a diminuição do potencial de reflexão provocado por seus principais materiais, o asfalto e o concreto, e através da relação do sistema de transportes com a forma de ocupação urbana. Isto é, acredita-se que políticas eficientes de transporte, principalmente através do desestímulo ao 
transporte motorizado individual, são fundamentais para evitar que as áreas ocupadas por vias e materiais urbanos sejam cada vez maiores, e aumentem ainda mais, a contribuição do setor de transporte para o aquecimento global.

Incialmente serão apresentadas algumas medidas de aumento do potencial de reflexão dos materiais urbanos, entre eles o concreto e o asfalto. Estas medidas são classificadas como medidas técnicas de gerenciamento da radiação solar, dentro de um conjunto de práticas de combate as mudanças climáticas, chamado de geoengenharia. Segundo Scheneider (1996), a geoengenharia é a manipulação intencional e em larga escala do meio ambiente que tem como objetivo a redução das mudanças climáticas antropogênicas indesejadas. Ou seja, a geoengenharia busca reverter alguns aspectos das mudanças climáticas provocados pelo homem através de esquemas de modificação intencional do clima (Martins, 2009).

Um exemplo de medidas de geoengenharia são as técnicas de gerenciamento da radiação solar (SRM, sigla em inglês). Estas técnicas objetivam reduzir a capacidade da atmosfera de absorver a radiação solar através do aumento de sua capacidade de refletir radiação, ou seja, através do aumento de seu albedo (Martins, 2009). Segundo Juras (2010), as técnicas SRM oferecem um efeito de resfriamento, contrabalançando o aquecimento global causado pelo aumento das emissões de gases de efeito estufa.

Os métodos de manejo da SRM podem ser baseados em modificações na superfície, na troposfera, na atmosfera e no espaço. No entanto, considerando o objetivo deste trabalho, os métodos apresentados são focados nas modificações na superfície terrestre. Na seção 1 deste capítulo, foram apresentados estudos que aboradam o impacto das superfícies dos materiais urbanos no balanço de radiação global. A tabela a seguir apresenta algumas medidas de mitigação de geoengenharia propostas por esses estudos. Ainda que em sua maioria, apresentem medidas e resultados referentes à infraestrutura urbana em geral, ressalta-se novamente a grande parcela das cidades ocupadas por vias e pavimentos evidenciada na seção anterior. 
Tabela 17: Estudos sobre políticas de mitigação ao impacto da infraestrutura urbana no aquecimento global

Autores

Medidas

Resultados e observações

\begin{tabular}{|c|c|c|}
\hline $\begin{array}{l}\text { Myhre e Myhre (2003); } \\
\text { Foster et al (2007); }\end{array}$ & $\begin{array}{l}\text { Aumento de } 0.01 \text { no } \\
\text { albedo da superfície }\end{array}$ & $\begin{array}{l}\text { Uma redução no forçamento } \\
\text { radiativo entre } 0,53 \text { e } 1,2 \mathrm{Wm}^{2}\end{array}$ \\
\hline Campra et al (2008) & $\begin{array}{l}\text { Aumento de } 0.09 \text { no } \\
\text { albedo da superfície } \\
\text { de uma região } \\
\text { espanhola }\end{array}$ & $\begin{array}{c}\text { Aumento da forçante negativa em } \\
\text { uma média de } 19,8 \mathrm{Wm}^{2}{ }^{2}\end{array}$ \\
\hline Lenton e Vaughan (2009) & $\begin{array}{l}\text { Aumento do albedo } \\
\text { das áreas urbanas }\end{array}$ & $\begin{array}{c}\text { Para uma área urbana de } 15 \times 10^{12} \mathrm{~m}^{2} \text {, } \\
\text { estimou-se um forçamento radiativo } \\
\text { negativo de }-0.047 \mathrm{Wm}^{2}\end{array}$ \\
\hline \multirow{3}{*}{ Akbari et al (2009) } & $\begin{array}{l}\text { Manutenção de } \\
\text { telhados e pavimentos } \\
\text { em zonas tropicais e } \\
\text { temperadas }\end{array}$ & $\begin{array}{l}\text { Efeito global no forçamento radiativo } \\
\text { de compensar } 44 \mathrm{Gt} \text { de } \mathrm{CO}_{2} \text { emitidos }\end{array}$ \\
\hline & Telhados brancos & $\begin{array}{l}\text { A longo prazo oferecem uma } \\
\text { temperatura atmosférica equivalente } \\
\text { a redução de } 0,1 \text { toneladas de } \mathrm{CO}_{2} \\
\text { por } \mathrm{m}^{2} \text { alterado }\end{array}$ \\
\hline & $\begin{array}{l}\text { Pavimentos capazes } \\
\text { de aumentar a reflexão } \\
\text { solar em } 0.15\end{array}$ & $\begin{array}{c}\text { Compensação de } 0,04 \text { toneladas de } \\
\mathrm{CO}_{2} \text { equivalente por } \mathrm{m}^{2}\end{array}$ \\
\hline Menon et al (2010) & $\begin{array}{l}\text { Aumento do albedo } \\
\text { dos telhados em } 0.25 \mathrm{e} \\
\text { dos pavimentos } \\
\text { urbanos em } 0.15\end{array}$ & $\begin{array}{l}\text { Aumento de aproximadamente } \\
0.5 \mathrm{Wm}^{2} \text { no potencial de energia } \\
\text { refletida. Compensação equivalente a } \\
\quad 57 \mathrm{Gt} \text { de } \mathrm{CO}_{2} \text { emitidos }\end{array}$ \\
\hline
\end{tabular}

Fonte: Elaboração própria com base nos autores citados

No tocante as medidas de mitigação provenientes do impacto do setor de transportes relacionado à forma de ocupação urbana, ressalta-se a tendência do modo rodoviário em incentivar um modelo de cidade espraiado, principalmente quando não combinado a políticas eficientes de uso do solo urbano. Os subúrbios norte-americanos e a região da Barra da Tijuca podem ser citados como exemplos onde a facilidade de acesso às áreas centrais das cidades 
através de um sistema de transportes e de uma infraestrutura voltada ao automóvel, estimulou a moradia em locais afastados, ocasionou esse espraiamento ${ }^{7}$.

Ressalta-se então, que o espraiamento urbano, principalmente quando baseado em um sistema de transporte rodoviário, aumenta a demanda por infraestrutura. Neste caso, o aumento ocorre não só na quantidade de vias e pavimentos como também na infraestrutura urbana em geral, como postos de gasolina e terminais de transporte público, aumentando ainda mais as superfícies urbanas cobertas por materiais de baixo albedo. Percebe-se então, que a mitigação dos impactos da infraestrutura urbana de transportes está amplamente relacionada à políticas de mobilidade que relacionem transporte e uso do solo, principalmente através do desestímulo ao transporte motorizado.

$\mathrm{Na}$ literatura destacam-se duas práticas principais que relacionam o desestímulo do transporte motorizado particular a políticas de uso do solo. São elas: o Gerenciamento da Demanda de Mobilidade (DGM) e o Desenvolvimento Orientado ao Transporte Sustentável (DOTS). Ainda que nenhuma das duas esteja preocupada diretamente com o papel da infraestrutura urbana de transportes no aquecimento global, ao estimular medidas como redução do uso do automóvel e adensamento urbano, ambas auxiliam no controle da expansão da infraestrutura urbana de transportes.

O Gerenciamento de Demanda é um conjunto de estratégias cujo principal objetivo é buscar uma solução para o crescente aumento do tráfego e os problemas associados a eles, não ampliando a oferta de vias, mas administrando com eficiência os deslocamentos e os meios de transporte disponíveis nas cidades (ITDP, 2014). Algumas de suas estratégias são direcionadas a modificar a escolha do padrão de viagens dos indivíduos, incentivando o número de viagens fora do horário de pico, o uso de modos coletivos e não motorizados, e destinos próximos, com o intuito de aumentar a eficiência do sistema de transportes (BID, 2013).

Para o funcionamento eficaz das medidas de gerenciamento da mobilidade, é importante a congruência de incentivos positivos, as chamadas medidas para atrair, e os incentivos negativos, as medidas para afastar (BID, 2013). Alguns exemplos destes instrumentos podem ser observados na tabela a seguir e são discutidos em seguida.

\footnotetext{
${ }^{7}$ Por mais que este espraiamento ocorra principalmente nas classes com maior poder aquisitivo, as populações de mais baixa renda, ainda que por outros motivos, também tendem a sair das áreas centrais. Isto porque, devido a falta de politicas que controlem a especulação imobiliária das áreas centrais - regiões valorizadas entre outros motivos, pois possuem alta oferta de serviços e transporte - essa parcela da população tende a ocupar as áreas periféricas das cidades.
} 
Tabela 18: Incentivos e medidas do gerenciamento da mobilidade

Incentivos negativos (afastar)

\begin{tabular}{|c|c|}
\hline Preços dos combustíveis & Melhoria do transporte público \\
\hline Cobranças sobre a propriedade & Infraestrutura para bicicletas e \\
\hline do automóvel & pedestres \\
\hline $\begin{array}{l}\text { Cobranças pelo uso do } \\
\text { automóvel (Pedágio Urbano) }\end{array}$ & Mais opções de mobilidade \\
\hline Restrições ambientais & Conscientização dos cidadãos \\
\hline Gestão dos estacionamentos & Desenvolvimento urbano compacto \\
\hline
\end{tabular}

\section{Incentivos positivos (atrair)}

Fonte: Elaboração com base em BID (2013)

Os incentivos relacionados às medidas para afastar o transporte individual motorizado constituem-se basicamente de politicas de restrição ao uso do automóvel. Medidas como a cobrança sobre a propriedade do automóvel, através do corte dos benefícios tarifários e financeiros, limitam o número de veículos em circulação nas cidades. Da mesma forma, o corte de subsídios aos combustíveis e o consequente aumento do preço, influem de maneira direta na escolha de deslocamentos mais curtos e na racionalização do uso do automóvel (Broaddus et al, 2009).

A cobrança pelo uso do automóvel tem como principal finalidade valorizar o uso das vias e das áreas mais congestionadas. Isto é, fazer com que os condutores paguem pelo uso de algumas vias mais movimentadas (BID, 2013). Um exemplo de sucesso comumente apresentado é o caso da cidade de Londres. Criado com os objetivos de desestimular o uso do automóvel particular, reduzir os congestionamentos e apoiar investimentos em transporte público, a política conseguiu resultados bem sucedidos em um curto prazo.

Neste caso, durantes os seis primeiros meses de operação, observou-se uma redução de 60 mil carros em relação ao ano anterior. Deste total, $60 \%$ foi resultado da mudança de meio de transporte (do automóvel para o transporte público), 30\% da redução foram atribuídos a pessoas evitando dirigir no centro e os $10 \%$ restantes se deveu a práticas como o uso compartilhado do automóvel, a redução no número de deslocamentos, aumento dos deslocamentos fora dos horários de operação e ao aumento de ciclistas e motociclistas (Broaddus et al, 2009) 
As restrições ambientais se referem basicamente a cobrança pelo nível de emissão do veiculo e a intenção é estimular o cidadão a comprar automóveis menos poluentes. Para isso, existem zonas na cidade onde são permitidos apenas veículos com determinados níveis de emissão. Essa medida apresentou resultados positivos na Alemanha onde, no ano de 2008 foi inicialmente implantada em cidades como Berlim e Colônia e atualmente esta prática já é adotada nas principais cidades da Alemanha.

Por fim, as politicas de gestão de estacionamentos podem ser consideradas como uma das principais medidas capazes de controlar o uso do automóvel particular nas cidades. Isto porque, quanto mais vagas houver em uma cidade e quanto menor for seu preço, mais atraente será o uso do automóvel. Desta forma, estabelecer limites para uma oferta de estacionamento e regulamentar a localização destes, assim como cobrar pelo estacionamento na via publica, criar tarifas progressivas são exemplos de algumas práticas que desestimulam o uso do automóvel. (BID, 2013)

Conforme anteriormente apresentado, para que as políticas de gerenciamento da demanda por viagem sejam eficazes, é fundamental também a implantação dos chamados mecanismos positivos, como o desenvolvimento urbano compacto e a melhoria da infraestrutura para pedestres e ciclistas. Estas medidas estão amplamente relacionadas com aquelas incentivas pelo modelo de desenvolvimento urbano orientado ao transporte sustentável (DOTS). Desta forma, para que não se torne exaustivo, estas práticas serão apresentadas a seguir sobre a concepção do modelo DOTS.

Segundo o modelo DOTS, o desenvolvimento urbano e o sistema de transportes estão completamente interligados. Isto é, não existe desenvolvimento urbano sem a possibilidade de transporte, e o transporte também é um estímulo ao desenvolvimento urbano. Apresentando dois exemplos dessa ligação, um do desenvolvimento urbano impulsionado pelo transporte e outro o transporte impulsionando o desenvolvimento urbano, no caso do Rio de Janeiro, podemos citar as construções do Programa Minha casa, Minha vida e o caso de regiões como Barra e Recreio na zona oeste da cidade.

No primeiro caso, essas construções localizadas em regiões periféricas e distantes do centro criam a dependência da maior parte de seus moradores do transporte diário aos centros onde se encontram as ofertas de emprego, estudo e serviços de forma geral. No caso destes programas do governo, a situação se torna um pouco pior ao pensarmos que esta população em sua maioria é altamente dependente do serviço de transporte público. No caso da zona oeste do Rio de Janeiro percebe-se justamente o movimento contrário. Isto é, a maior disponibilidade de 
veículos automotores individuais possibilitou o cumprimento de maiores distâncias diárias e fez com que pessoas em sua maioria de renda mais alta buscassem um refúgio do caos central em zonas mais afastadas e tranquilas.

Atualmente, esta situação atingiu um estágio de saturação onde se perdem longas horas diariamente no trânsito para o cumprimento destas distâncias. Somam-se a estes desgastes sociais, os impactos ambientais e econômicos, visto que este modelo de urbanização além da alta emissão de gases poluentes demanda ampla infraestrutura urbana de transportes e aumento do custo de vida dos cidadãos. Desta forma, o modelo de desenvolvimento urbano orientado ao transporte tem por objetivo integrar o uso do solo ao sistema de transportes, promovendo cidades mais sustentáveis, em termos ambientais, econômicos e sociais (ITDP, 2013).

O modelo DOTS implica em um planejamento cuidadoso e em uma concepção de características de uso do solo e de formas de construção que apoiam, facilitam e priorizam não só o uso do transporte de alta capacidade, mas também o pedestre e a bicicleta (ITDP, 2013). De acordo com Cevero (2007), o principal benefício desse tipo de iniciativa é o incremento no uso do transporte coletivo e, além disso, devido ao menor uso de carros de passeio, efeitos benéficos como menor emissão de gases poluentes e bairros mais compactos voltados aos deslocamentos não motorizados.

Segundo a EMBARQ (2014), a metodologia para se alcançar um desenvolvimento orientado ao transporte sustentável consiste na aplicação de um conjunto de estratégias, critérios e recomendações de desenho urbano, concentradas em diferentes áreas. Destacam- se aqui, aquelas capazes de mitigar o impacto da infraestrutura de transportes no aquecimento global: (i) gestão do uso do automóvel; (ii) mobilidade não motorizada; (iii) transporte coletivo de qualidade. A tabela 19 apresenta estas estratégias e suas diferentes áreas de atuação. 
Tabela 19: Estratégias DOTS e diferentes áreas de atuação

Níveis de atuação

\begin{tabular}{|c|c|c|c|c|}
\hline $\begin{array}{c}\text { Áreas } \\
\text { estratégicas }\end{array}$ & Cidade & Interbairros & Bairros & Rua \\
\hline $\begin{array}{l}\text { Gestão do uso } \\
\text { do automóvel }\end{array}$ & $\begin{array}{l}\text { Otimização dos } \\
\text { percursos diários }\end{array}$ & $\begin{array}{l}\text { Vias seguras } \\
\text { e ordenadas }\end{array}$ & $\begin{array}{c}\text { Gestão dos } \\
\text { estacionamentos }\end{array}$ & $\begin{array}{l}\text { Segurança } \\
\text { viária }\end{array}$ \\
\hline $\begin{array}{c}\text { Mobilidade não } \\
\text { motorizada }\end{array}$ & $\begin{array}{l}\text { Continuidade do } \\
\text { traçado viário }\end{array}$ & $\begin{array}{l}\text { Redes para } \\
\text { pedestres e } \\
\text { ciclistas }\end{array}$ & $\begin{array}{c}\text { Conectividade } \\
\text { Interna }\end{array}$ & $\begin{array}{l}\text { Calçadas e } \\
\text { Ciclovias }\end{array}$ \\
\hline $\begin{array}{l}\text { Transporte } \\
\text { coletivo de } \\
\text { qualidade }\end{array}$ & $\begin{array}{l}\text { Proximidade com a } \\
\text { mancha urbana }\end{array}$ & $\begin{array}{c}\text { Viabilidade } \\
\text { do transporte } \\
\text { coletivo }\end{array}$ & $\begin{array}{l}\text { Acesso ao } \\
\text { transporte } \\
\text { coletivo }\end{array}$ & $\begin{array}{c}\text { Infraestrutura } \\
\text { para o } \\
\text { transporte } \\
\text { coletivo }\end{array}$ \\
\hline
\end{tabular}

Na esfera da gestão do uso do automóvel essas medidas reconhecem que as políticas de incentivo ao uso do automóvel privado além dos altos investimentos em infraestrutura para este tipo de transporte beneficiam uma parcela pequena da população e provocam impactos expressivos a todos que circulam nos centros urbanos. Desta forma, assim como o mecanismo de gerenciamento de demanda de viagem, o modelo DOTS reconhece a urgência da necessidade de mudança deste padrão.

Para o setor de mobilidade não motorizada, destaca-se que todas essas estratégias estão estruturadas em um princípio comum que é o incentivo ao transporte não motorizado não apenas como "uso recreativo", mas também como uma forma de transporte eficiente. Segundo o documento, as rotas devem se conectar a diferentes centros de interesse e de atração de fluxo de pedestres e ciclistas, ou seja, interliguem de maneira eficiente os "destinos-chave" da comunidade.

Destaca-se que para o incentivo ao transporte não motorizado e a diminuição do uso do automóvel particular funcionarem de maneira desejada, a oferta de um transporte coletivo de qualidade deve ser considerada como um pré-requisito. De uma forma geral, o documento sugere que a oferta de transporte esteja relacionada com a sua demanda; caracterizando o tipo do transporte coletivo e os pontos de parada segundo a mesma.

Percebe-se que estes novos padrões de construção criados para a promoção de cidades mais eficientes, incentivam a reorientação das politicas e estratégias de desenvolvimento 
urbano de forma a integra-las ao planejamento da cidade e de seus sistemas de transporte, tornando-as, por exemplo, mais densas e compactas (EMBARQ, 2014). Ainda que estas novas políticas de mobilidade, como o gerenciamento da demanda de viagem e o desenvolvimento orientado ao transporte não considerem diretamente os impactos da infraestrutura urbana no aquecimento global, eles contribuem também para a mitigação. Isto porque tendem a desestimular o uso do automóvel particular e incentivar cidades mais compactas, controlando o crescimento dos espaços de baixo albedo, ajudando a equilibrar o balanço de radiação terrestre. 


\section{Capítulo 4: Estudo de caso do impacto da infraestrutura urbana}

\section{de transportes no Rio de Janeiro e sua contribuição para o aquecimento global}

\subsection{Contextualização sobre a área de estudo}

Os modelos de desenvolvimento urbanos atuais demandam das cidades grandes áreas de vias destinadas principalmente ao transporte motorizado particular. Ao basear o desenvolvimento urbano das cidades nestes modelos, provoca-se o crescimento de diversos impactos ambientais. A escolha da cidade do Rio de Janeiro para este estudo de caso se deve ao fato desta estar localizada em um país em desenvolvimento e ser a segunda maior metrópole brasileira. Destaca-se também, que esta é a principal cidade de um Estado que atualmente experimenta um crescimento acelerado (CEPERJ, 2013).

A cidade do Rio de Janeiro é a capital do estado do Rio de Janeiro, localizado na região sudeste do Brasil. Segundo dados do IBGE (2016), dos 16 milhões de habitantes do estado do Rio de Janeiro, 6,3 milhões residem no município do Rio de Janeiro. Apesar de abrigar mais de $35 \%$ da população do estado, a cidade do Rio ocupa uma área de $1.200 \mathrm{~km}^{2}$, que representa uma porcentagem simbólica da área total do estado, de $53.696 \mathrm{~km}^{2}$. Desta forma, a cidade do Rio de Janeiro apresenta uma densidade demográfica 14 vezes maior que a média do estado, com valores de 5.265,82 hab/ $\mathrm{km}^{2}$ e 365,23 hab $/ \mathrm{km}^{2}$ respectivamente (IBGE, 2016 e CEPERJ, 2013).

Segundo o Atlas de Desenvolvimento Humano (Atlas Brasil, 2013), o Índice de Desenvolvimento Humano $^{8}$ do município do Rio de Janeiro em 2010 era de 0,79 . Tal pontuação situa o município na faixa de desenvolvimento alta. De acordo com o estudo, a dimensão que mais contribuiu para o alto IDHM (Índice de Desenvolvimento Humano Municipal) do município é longevidade, seguida de renda e educação. No tocante à oferta de trabalho no município, observa-se que $64,5 \%$ da população é economicamente ativa e ocupada, $28,3 \%$ da população é economicamente inativa e os restantes $7,3 \%$ são a população economicamente ativa, mas desocupada. Da população economicamente ativa no município, o setor com mais trabalhadores é o setor de serviços com $61,9 \%$ da população economicamente ativa e o setor com menos trabalhadores é agropecuário, com apenas 0,31\% (Atlas Brasil, 2013).

\footnotetext{
${ }^{8} \mathrm{O}$ Índice de Desenvolvimento Humano Municipal é calculado com base em três indicadores: longevidade, educação e renda do município. $\mathrm{O}$ índice varia de 0 a 1 e quanto mais próximo de 1 , maior o desenvolvimento humano municipal.
} 
A oferta de empregos e serviços atrai para o município do Rio de Janeiro diariamente milhares de habitantes dos municípios vizinhos. A Casa Fluminense aponta que grande parte da população residente em municípios da Região Metropolitana do Rio de Janeiro trabalha no município do Rio de Janeiro (Fórum Rio, s.d.). Segundo o estudo, nos municípios de Mesquita, Nilópolis e Queimados respectivamente 40\%, 42\% e 37\% da população residente possui emprego na capital do estado. Essa concentração de oferta de emprego no município do Rio de Janeiro implica na realização de longas viagens diárias e, segundo dados do PDTU (Rio de Janeiro, 2015b) pode-se esperar que este padrão irá se manter. A estimativa é que, em 2022 o município do Rio de Janeiro corresponda a $72 \%$ do total de empregos formais do Estado, seguido por Duque de Caxias, com 6,2\%.

Como aponta Santos (2014), a história do Rio está intimamente ligada ao meio ambiente. Além de ter sido sede de duas importantes conferências internacionais sobre o clima, a Rio 92 e a Rio +20, o Rio de Janeiro foi uma das primeiras cidades do país a definir uma Política Municipal de Mudança Climática de Desenvolvimento Sustentável, estabelecendo metas de redução e de mitigação de gases de efeito estufa. A prefeitura criou também o Fórum Carioca de Mudanças Climáticas e Desenvolvimento Sustentável, cujo objetivo é encontrar soluções viáveis para reduzir e combater os efeitos das mudanças climáticas na cidade (Rio de Janeiro, 2010). Recentemente, outra prática do município relacionada às mudanças climáticas foi a criação do programa Rio Resiliente, lançado em 2015.

O programa Rio Resiliente é uma estratégia pioneira que aponta as principais orientações da cidade para enfrentar impactos e se adaptar a choques e estresses crônicos causados pelas mudanças climáticas e desafios urbanos (Cunha, 2015). No caso da cidade do Rio, a vulnerabilidade frente às mudanças climáticas ocorre por características geográficas, devido ao fato de a cidade estar situada entre áreas de restingas e lagoas, ou também devido ao numeroso contingente populacional de baixa renda vivendo em áreas vulneráveis a eventos meteorológicos extremos (UN-HABITAT, 2011).

De acordo Nobre (2010), o clima no município do Rio de Janeiro está se tornando mais úmido e a temperatura cada vez mais quente. Ao reconhecer que estas mudanças no clima provocarão impactos diretos na segurança e qualidade de vida da população, o programa Rio Resiliente identifica as áreas de vulnerabilidades na cidade e apresenta uma estratégia de resiliência para o futuro da cidade. Dentre as áreas analisadas estão quatro tipos principais de riscos: naturais, tecnológicos, sociais e econômicos (Rio de Janeiro, 2015). 
Como ponto de partida, o programa destacou as principais ameaças da cidade relacionadas às mudanças climáticas: chuvas intensas, ondas e ilhas de calor, ventos fortes, elevação do nível do mar, secas, dengue e outras epidemias. Outros desafios abordados no programa se referem, por exemplo, a mobilidade e as condições de infraestrutura urbana. A tabela 20 apresenta algumas dessas ameaças assim como algumas observações e seus principais impactos para a cidade. Em seguida, são destacadas duas ameaças principais que se relacionam diretamente com a relação entre infraestrutura urbana de transportes e aquecimento global. 
Tabela 20: Riscos e Consequências Identificadas no Programa Rio Resiliente Principais Riscos Identificados

$$
\text { Principais Consequências Observações }
$$

\begin{tabular}{|c|c|c|}
\hline Chuvas Fortes & $\begin{array}{l}\text { Alagamentos na cidade; } \\
\text { deslizamentos de terra; falta de } \\
\text { energia elétrica e acidentes de } \\
\text { trânsito. }\end{array}$ & $\begin{array}{l}\text { Nos últimos anos o período de } \\
\text { chuva está se tornando mais } \\
\text { extenso e com maior potencial } \\
\text { destrutivo. }\end{array}$ \\
\hline $\begin{array}{c}\text { Ondas e Ilhas de } \\
\text { Calor }\end{array}$ & $\begin{array}{c}\text { Aumento de doenças } \\
\text { respiratórias; aumento de casos } \\
\text { de hipertermia, aumento do } \\
\text { consumo de energia elétrica. }\end{array}$ & $\begin{array}{l}\text { Estima-se que bairros como } \\
\text { Bangu, Realengo e Santa Cruz } \\
\text { sejam os mais propensos a } \\
\text { formarem Ilhas de Calor. }\end{array}$ \\
\hline $\begin{array}{c}\text { Elevação do } \\
\text { nível máximo do } \\
\text { mar }\end{array}$ & $\begin{array}{l}\text { Contaminação de água potável; } \\
\text { áreas habitadas ainda mais } \\
\text { suscetíveis a inundações; } \\
\text { diminuição da faixa de areia. }\end{array}$ & $\begin{array}{l}\text { As obras do Porto Maravilha, } \\
\text { iniciadas em } 2010 \text { incorporou a } \\
\text { possibilidade do aumento do } \\
\text { nível do mar na região de até um } \\
\text { metro. }\end{array}$ \\
\hline
\end{tabular}

\begin{tabular}{ccc}
\hline \multirow{2}{*}{$\begin{array}{c}\text { Epidemia local e } \\
\text { pandemia }\end{array}$} & $\begin{array}{c}\text { Desabastecimento de itens } \\
\text { hospitalares; saturação de } \\
\text { serviços de saúde, assistência } \\
\text { social e defesa civil. }\end{array}$ & $\begin{array}{c}\text { As mudanças climáticas podem } \\
\text { tornar mais difícil combater a } \\
\text { dengue e o chikunguya. }\end{array}$ \\
\hline Interrupção geral e prolongada & $\begin{array}{c}\text { O crescimento populacional da } \\
\text { cidade não foi devidamente }\end{array}$ \\
Infraestrutura & do fornecimento de energia & acompanhado por expansões e \\
urbana & urbana a partir de acidentes com & modernizações da sua \\
& trens, metrôs e ônibus. & infraestrutura urbana. \\
Saturação da & qualidade de vida de cidadãos; & melhorias significativas na \\
Infraestrutura & piora da qualidade do ar; & infraestrutura viária, \\
viária & diminuição da capacidade de & especialmente no transporte de \\
& mobilização durante crises. & massa no Rio de Janeiro.
\end{tabular}


Destacam-se para o escopo deste trabalho, dentre os principais riscos identificados pelo programa Rio Resiliente, as ondas e ilhas de calor e a saturação da infraestrutura viária. As ondas e ilhas de calor são importantes tendo em vista que são em grande parte provocadas pela infraestrutura urbana, onde se inclui a infraestrutura urbana de transporte. No tocante a saturação da infraestrutura viária, este impacto é aqui relevante, pois, dentro do atual modelo de desenvolvimento urbano e de transporte, a saturação da infraestrutura viária aumenta a demanda por mais infraestrutura, alimentando um ciclo vicioso, que provoca o aumento na radiação retida na superfície terrestre (ver capítulo 2).

Considera-se que há uma onda de calor quando, por dias consecutivos, as temperaturas se mantêm elevadas. Ondas de calor são consideradas eventos climáticos extremos com grande potencial de letalidade e já há evidências de que, no Rio de Janeiro as ondas de calor estão se tornando mais frequentes e com maior duração (Rio de Janeiro, 2015). Já as Ilhas de calor são áreas nos centros urbanos onde a temperatura é mais alta que aquelas ao seu redor. Segundo Lombardo (1985), essas variações de temperatura podem chegar a $10^{\circ} \mathrm{C}$, tendo como causas principais ações antrópicas, como a substituição da vegetação natural pelo excesso de concreto e asfalto e o adensamento das edificações.

Outros autores que relacionam esta diferença de temperatura as características de materiais de construção usados nas cidades, que absorvem e retêm mais calor são Oke (1987); Alcoforado et al (2009) e Gartland (2010). De acordo com Hebber e Jankovic (2013), o interesse científico do efeito da urbanizaçao na atmosfera, ultrapassa os 200 anos. No entanto, como destacam os autores, a importância do processo de urbanização para o clima global foi tratada pela primeira vez no quarto relatório do IPCC (IPCC, 2007) e em seu quinto relatório o IPCC afirma que as ilhas de calor são um fenômeno real e que estão cada vez mais presentes nos centros urbanos (IPCC, 2014c).

Algumas medidas de mitigação ao efeito das ilhas de calor como o aumento da arborização, instalação de tetos verdes e aumento da permeabilização do solo são apresentadas no estudo do programa Rio Resiliente. Ressalta-se aqui, a relação destas com as medidas de mitigação do impacto da infraestrutura urbana no aquecimento global por autores como Akbari et al (2003) e Menon et al (2009) no capítulo 2. Percebe-se que as ilhas de calor são apenas mais um exemplo dos diversos impactos ambientais resultantes da ação do homem no meio ambiente. Hebbert e Jankovic (2013) apontam uma série de práticas de mitigação a estes impactos, como reduzir as áreas de estacionamento na superfície, introduzir vegetação em 
superfícies urbanas, desencorajar o uso do automóvel particular, aumentar o potencial reflexivo das cidades, entre outras.

No que se refere ao risco da saturação da infraestrutura viária, percebe-se que o Rio de Janeiro, assim como a maioria das metrópoles brasileiras e diversas cidades ao redor do mundo optou por políticas de transportes que privilegiam o modo rodoviário e uso de automóveis particulares. A produção de veículos no Brasil no período de 1960 a 2009 evidencia bem esta escolha. Segundo Vasconcellos (2006), neste período, a produção de automóveis particulares foi multiplicada por 60 enquanto a produção de ônibus foi multiplicada apenas por oito. Desta forma, segundo o autor, em 2009 o Brasil produziu um total de 2.575.418 automóveis e 34.535 ônibus.

Externalidades negativas atreladas a este modelo de desenvolvimento como o aumento das emissões de gases de efeito estufa e das superfícies cobertas por materiais escuros e com alto potencial de absorção de radiação foram amplamente discutidas no capítulo 2. Pode-se considerar que as características do modelo de desenvolvimento e do setor de transportes evidenciam a discrepância entre os modelos de cidades brasileiras do século XXI e as práticas de mitigação dos impactos ambientais urbanos apresentadas por Hebbert e Jankovic (2013) anteriormente.

\subsection{A infraestrutura de transporte do Rio de Janeiro e sua} contribuição para o Aquecimento Global

A participação da infraestrutura urbana de transportes na contribuição antrópica do aquecimento global foi calculada partindo da premissa de que o equilíbrio do sistema climático é baseado no equilíbrio entre a radiação solar que entra na superfície terrestre e a radiação refletida de volta para a atmosfera. Desta forma, quaisquer fatores que interfiram nesse equilíbrio contribuem para o aquecimento, se aumentarem a quantidade de radiação retida na superfície terrestre ou para o esfriamento, caso contrário (ver capítulo 1).

Conforme apresentado, as superfícies destinadas à infraestrutura urbana de transportes, usualmente são caracterizadas por coberturas escuras, de baixo albedo. Desta forma, para calcular o impacto da infraestrutura urbana de transportes da cidade do Rio de Janeiro no aquecimento global, este estudo de caso calculou o total de radiação solar absorvida por estas superfícies. Cabe mencionar, que esta pesquisa considerou apenas as áreas de vias urbanas na avaliação do impacto.

A metodologia usada foi dividia em três partes principais, que são aqui apresentadas separadamente. A primeira delas foi o uso do Sistema de Informações Geográficas (SIG) para 
calcular as áreas de vias totais na cidade do Rio de Janeiro. Nesta parte, é apresentada primeiramente uma introdução ao SIG (4.2.1a) e em seguida, as etapas realizadas neste sistema para a identificação das áreas de via na cidade (4.2.1b). Por fim, esta parte apresenta o cálculo final da área total de vias na cidade do Rio de Janeiro (4.2.1c).

A segunda parte foi baseada na revisão da literatura para calcular a radiação solar absorvida pela superfície asfáltica. Nesta parte, são apresentados primeiramente os elementos necessários para este cálculo - a incidência solar e o albedo da superfície (4.2.2a). Desta forma, em seguida, são identificados a radiação solar incidente na cidade do Rio de Janeiro e o albedo da superfície asfáltica (4.2.2b).

A terceira parte então é baseada nas informações adquiridas de área total de vias urbanas e da radiação absorvida por estas superfícies. Desta forma, esta parte (4.2.3) apresenta o cálculo da radiação total absorvida pelas vias na cidade do Rio de Janeiro. A metodologia aqui utilizada pode ser observada no esquema apresentado a seguir.

Figura 11: Esquema da metodologia utilizada no estudo de caso

\begin{tabular}{|c|c|c|c|}
\hline Etapa 1 & $\begin{array}{c}\text { Introdução ao SIG } \\
(4.2 .1 . \mathrm{a})\end{array}$ & $\begin{array}{c}\text { Identificação das áreas de via na } \\
\text { cidade }(4.2 .1 . \mathrm{b})\end{array}$ & $\begin{array}{c}\text { Cálculo da área de via total no } \\
\text { município }(4 \cdot 2.1 . \mathrm{c})\end{array}$ \\
\hline Etapa 2 & $\begin{array}{c}\text { Elementos para cálculo da } \\
\text { absorção de radiação solar } \\
(4.2 .2 . \mathrm{a})\end{array}$ & $\begin{array}{l}\text { Identificação da incidência solar no } \\
\text { Rio de Janeiro (4.2.2.b) }\end{array}$ & $\begin{array}{l}\text { Determinação do albedo da } \\
\text { superfície asfáltica }(4 \cdot 2.2 . c)\end{array}$ \\
\hline Etapa 3 & $\begin{array}{l}\text { Resultado da Parte } 1 \\
\text { (Área total de vias) }\end{array}$ & $\begin{array}{l}\text { Resultado da Parte } 2 \text { (Absorção } \\
\text { da radiação pela superfície asfáltica) }\end{array}$ & $\begin{array}{l}\text { Total de radiação solar } \\
\text { absorvida pela área de via no } \\
\text { município do RJ }(4.2 .3)\end{array}$ \\
\hline
\end{tabular}

Fonte: Elaboração Própria

\subsection{1 Área total da infraestrutura urbana de transportes no Rio de Janeiro (Etapa} 1)

\subsection{1.a O sistema de Informações Geográficas}

O impacto da infraestrutura urbana do setor de transportes aqui apresentado, considerou exclusivamente o impacto no potencial de reflexão refletida provocado pelas vias urbanas. Isto porque, tendo em vista que esta análise foi feita a partir do processamento de dados geográficos e imagens de satélite, áreas como estacionamentos e outras infraestruturas de transporte, não poderiam ser identificadas em sua totalidade. Além disto, considera-se que as áreas de vias são a principal evidência da escolha pelo modo de transporte rodoviário, caracterizando o impacto deste setor no aquecimento global. 
Atualmente, o processamento de dados geográficos, conhecido como geoprocessamento, é uma prática muito utilizada. O geoprocessamento é possível devido aos Sistemas de Informações Geográficas (SIG), que atualmente são sistemas de baixo custo e com interfaces amigáveis, o que permite que seja usado em diferentes áreas (Cruz e Campos, 2005 $e$ Câmara et al, 2004). Segundo Câmara et al (2004), o SIG é um sistema automático que realiza o tratamento computacional de dados geográficos e armazena a geometria e atributos dos dados que estão georreferenciados, isto é, localizados na superfície terrestre e representados em uma projeção cartográfica.

Tal ferramenta permite uma percepção visual dos dados, capaz de traduzir padrões existentes, facilitar o entendimento de problemas assim como projetar possíveis soluções e medidas mitigadoras em diferentes áreas (Cruz e Campos, 2005). As aplicações do SIG são as mais diversas, onde a ideia central é incorporar o espaço à análise que se deseja fazer. A tabela a seguir apresenta algumas áreas de aplicação do SIG em cinco diferentes grupos: ocupação humana, uso da terra, uso de recursos naturais, meio ambiente e atividades econômicas.

Tabela 21: Grupos do Sistema de Informações Geográficas e suas áreas de aplicação

\section{Áreas de Aplicação do SIG}

\begin{tabular}{|c|c|}
\hline Ocupação & Redes de infraestrutura; roteamento de veículos; \\
\hline Humana & planejamento urbano; mapeamento de rede de ensino, etc. \\
\hline Uso da Terra & $\begin{array}{l}\text { Planejamento agropecuário; de barragens; cadastramento de } \\
\text { propriedades rurais, etc. }\end{array}$ \\
\hline Uso de Recursos & Classificação de poços petrolíferos; planejamento de \\
\hline Naturais & gasodutos e oleodutos; distribuição de energia elétrica \\
\hline Meio Ambiente & $\begin{array}{l}\text { Controle de queimadas; estudos de modificações climáticas; } \\
\text { acompanhamentos de emissão, etc. }\end{array}$ \\
\hline Atividades & Pesquisas socioeconômicas, distribuição de produtos e \\
\hline Econômicas & serviços, transporte de matéria-prima, etc. \\
\hline
\end{tabular}
Fonte: Adaptação de Oliveira (1997) apud Cruz e Campos (2005)

No caso do setor de transportes, existe um Sistema de Informação Geográfica específico para o setor, conhecido como SIG-T (Sistema de Informação Geográfica - Transporte). Os SIGT referem-se a princípios e aplicações da utilização de tecnologias da informação geográfica orientados a temática de transportes, facilitando a representação e análise do sistema de transportes e suas particularidades (Miller e Shaw, 2015 e Silva, 2005) A tabela 22 apresenta 
as funções mais comuns do SIG-T e a forma como estas podem participar de ações de planejamento e gestão de transportes. 
Tabela 22: Funções do SIG-T e suas ações de planejamento e gestão de transportes

Funções: $\quad$ Contribuição a ações de planejamento e gestão de transportes

\begin{tabular}{|c|c|}
\hline $\begin{array}{l}\text { Integração e } \\
\text { gestão da } \\
\text { informação }\end{array}$ & $\begin{array}{l}\text { Permite a gestão de grande quantidade de informação, refente as } \\
\text { infraestruturas do sistema (rede rodo e ferroviária, percursos de } \\
\text { transporte público, etc), à sua utilização (fluxos por modo de transporte) } \\
\text { e informação auxiliar (demografia, usos do solo, etc). }\end{array}$ \\
\hline & $\begin{array}{l}\text { ermite a integração, eliminação ou alteração de entidades geográficas. } \\
\text { om isto, a rede de transportes pode estar sempre conectada, permitindo } \\
\text { analise de fluxos e operações de forma eficiente. }\end{array}$ \\
\hline $\begin{array}{l}\text { Manipulação, } \\
\text { visualização e } \\
\text { mapeamento }\end{array}$ & $\begin{array}{l}\text { Permite uma representação diferenciada dos vários tipos de vias, } \\
\text { infraestruturas e equipamentos de apoio ao sistema de transporte. Sendo } \\
\text { assim, facilitam a forma como essas análises são interpretadas e } \\
\text { disseminadas, diminuindo a lacuna entre as análises e a comunicação. }\end{array}$ \\
\hline $\begin{array}{c}\text { Sobreposição } \\
\text { (overlay) }\end{array}$ & $\begin{array}{l}\text { Operação de sobreposição de temas (layers, camadas de informação). Em } \\
\text { transportes, uma simples operação de sobrepor o tema da rede viária } \\
\text { sobre uma carta de usos do solo é capaz de fornecer informação essencial } \\
\text { para tarefas de planejamento. }\end{array}$ \\
\hline $\begin{array}{l}\text { Área de } \\
\text { vizinhança } \\
\text { (buffer) }\end{array}$ & $\begin{array}{l}\text { Define o crescimento de uma zona em volta de uma determinada } \\
\text { entidade geográfica, criando uma área onde pretende-se realizar a } \\
\text { análise. Permite, por exemplo, determinar o número de população ou } \\
\text { habitações que estão em uma determinada proximidade de paradas de } \\
\text { transportes coletivos. }\end{array}$ \\
\hline
\end{tabular}

Permite inquirir a base de dados de acordo com determinados critérios.

Consulta (query) As consultas podem ser espaciais e não espaciais. A contribuição do SIG é referente as propriedades espaciais da informação.

\begin{tabular}{cl}
\hline & Cria uma superfície onde se pode visualizar as três dimensões, a \\
Modelação do & morfologia do terreno e mesmo os objetos (construções). É de grande \\
terreno 3D & utilidade em tarefas de planejamento e desenho de novas infraestruturas \\
& de transportes. \\
\hline Georeferenciação & Converte informações de moradias em pontos que identificam \\
de endereços & determinadas localizações. É utilizável em transportes, por exemplo, a \\
(geocoding) & $\begin{array}{l}\text { partir da referenciação de acidentes em espaço urbano com vista a uma } \\
\text { rápida assistência pelos serviços de emergência médica. }\end{array}$
\end{tabular}




\subsection{1.b O Sistema de Informação Geográfica e a identificação das áreas de via na cidade do}

\section{Rio de Janeiro}

No caso deste estudo, o Sistema de Informações Geográficas permitiu uma análise diferenciada do Sistema de Transportes a partir das áreas de vias na cidade do Rio de Janeiro. Dentre as funções apresentadas na tabela 22, para a realização deste estudo de caso foram usadas principalmente a edição e sobreposição dos dados. Tais ferramentas permitiram a identificação das áreas de vias na cidade, facilitando o cálculo da área total de vias na cidade do Rio de Janeiro.

Inicialmente, os dados geográficos utilizados neste estudo foram as ortofotos (fotos corrigidas de todas as deformações presentes nas fotografias aéreas) da cidade do Rio de Janeiro do ano de 2015 e o mapeamento das áreas quadras para a mesma localização. Estes dados foram disponibilizados pelo Instituto Municipal de Urbanismo Pereira Passos (IPP) e foram trabalhados no software ArcGIS 10.2. A sobreposição destas duas informações neste software permitiu a análise do sistema viário na cidade, garantindo um alto grau de confiabilidade sobre o cálculo total da área ocupada por vias na cidade.

O IPP mapeou as áreas de quadras na cidade pela primeira vez em 1997. No ano de 2000, este mapeamento recebeu a primeira atualização, apenas para algumas áreas da cidade. Recentemente em 2013, o município atualizou esta informação também somente para algumas áreas, com o foco principalmente na Zona Oeste, considerando o crescimento da região. Desta forma, o mapeamento das áreas de quadra da cidade do Rio de Janeiro agrega informações de três anos diferentes: 1997, 2000 e 2013.

Da área total do município, o mapeamento das áreas de quadras realizado pelo IPP, não identificou principalmente as áreas de vias da cidade. Isto é, ao identificar somente as quadras urbanas em relação a área total do município, o mapeamento da área de quadras identificou por exclusão, as áreas de via na cidade. Ou seja, apesar de algumas aproximações como canteiros centrais, dentre as áreas não mapeadas a maioria expressiva é ocupada por áreas de vias destinadas principalmente ao transporte motorizado.

A figura 12 a seguir apresenta espacialmente o mapeamento das áreas de quadra, partindo de uma apresentação geral da cidade do Rio de Janeiro para um enfoque em uma zona específica. A figura 13 em seguida, apresenta um enfoque mais detalhado, identificando as vias na imagem superior e as áreas de quadra na imagem inferior. 
Figura 12: Identificação das áreas de vias na cidade do Rio de Janeiro - Enfoque abrangente

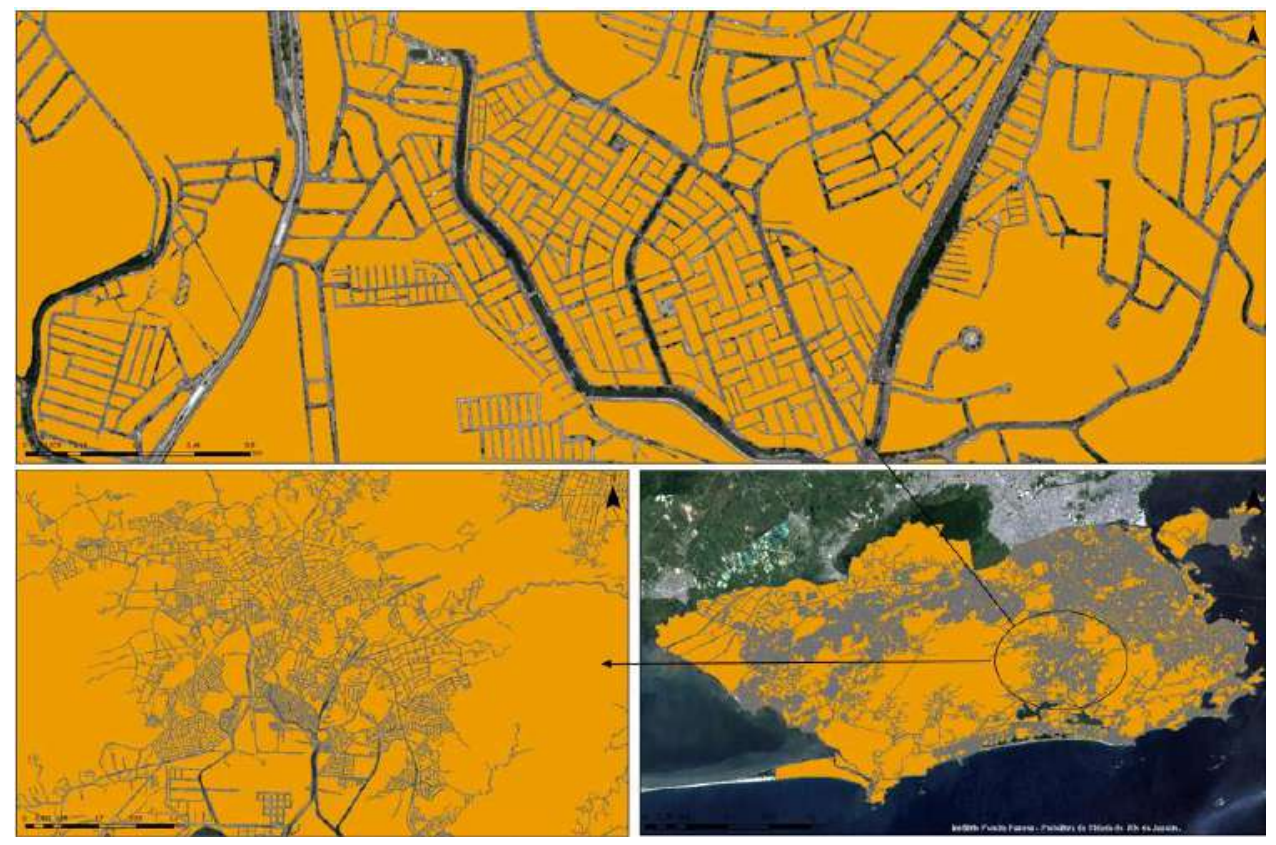

Fonte: Elaboração própria com base em Armazém de Dados IPP

Figura 13: Identificação das áreas de vias na cidade do Rio de Janeiro - Enfoque localizado

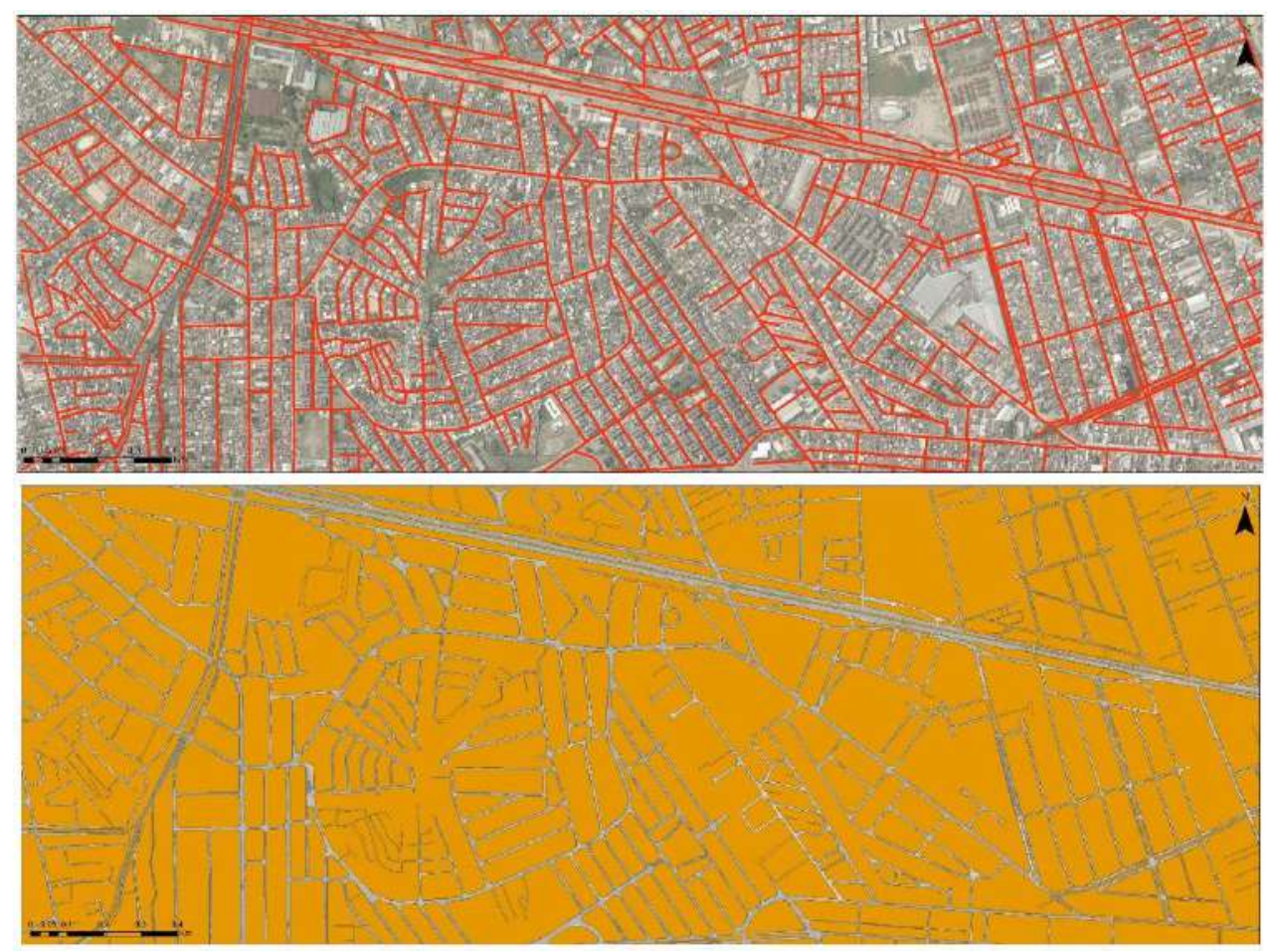

Fonte: Elaboração própria com base em Armazém de Dados IPP 
Conforme apresentado, a área de quadra total, urilizada neste estudo de caso considera informações de três anos distintos (1997, 2000 e 2013). Para que fosse possível a utilização conjunta destes mapeamentos, de forma a utilizar as informações mais atualizadas sempre que possível, foram realizados três procedimentos, apresentados separadamente a seguir:

\section{$1^{\circ}$ Procedimento - Ferramenta Erase}

O primeiro procedimento realizado foi através do uso da ferramenta erase. Esta ferramenta sobrepõe uma camada de informações, neste caso o mapeamento dos anos de 1997 e $2000^{9}$, a outra camada, no caso, a área referente ao mapeamento do ano de 2013. Como resultado, a ferramenta erase cria uma nova camada somente com as porções que não se enquadram na camada sobreposta. Entende-se aqui como camada a representação de um mapa e de suas informações dentro do programa de sistema de informações utilizado. Desta forma, o primeiro procedimento forneceu a informação das áreas de quadra que não possuíam a informação atualizada para o ano de 2013 (figura 14).

Figura 14: Resultado 1 da Ferramenta Erase - Áreas de quadras do município do Rio de Janeiro

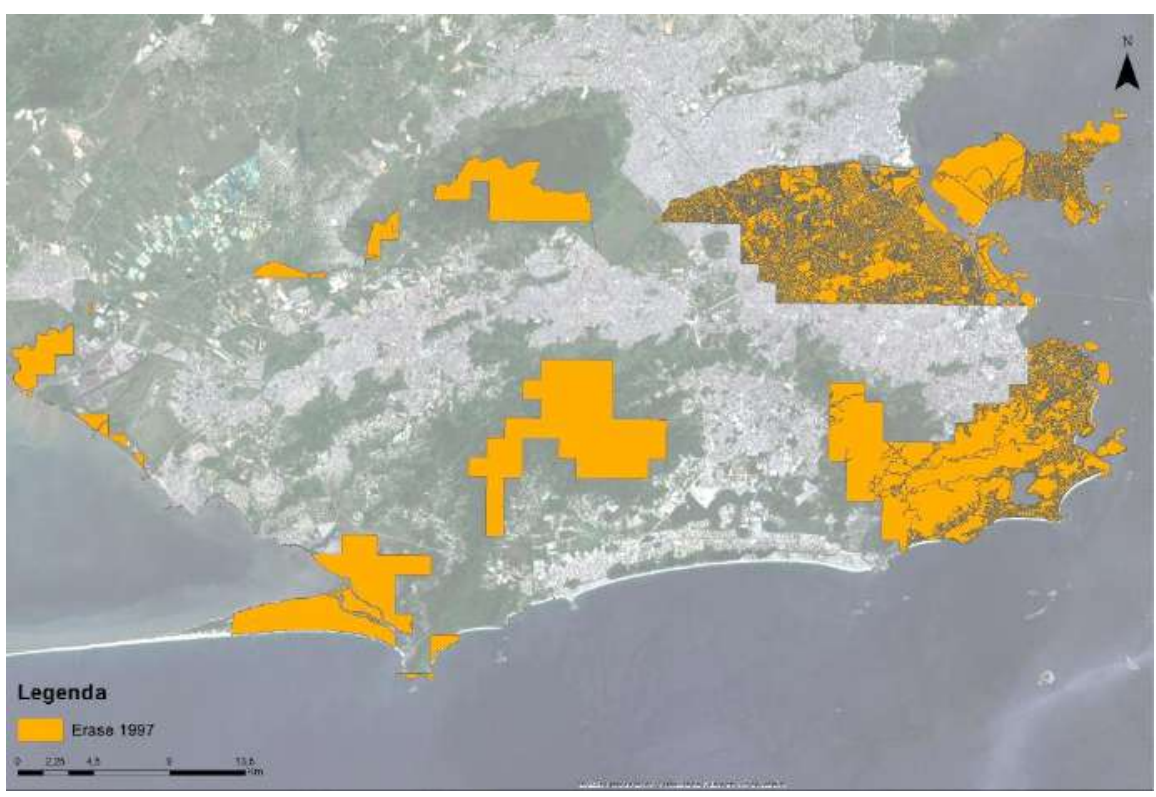

Fonte: Elaboração própria com base em Armazém de Dados IPP

\footnotetext{
${ }^{9}$ A utilização conjunta do mapeamento dos anos de 1997 e 2000 foi porque o mapeamento de 2000 é apenas uma atualização do mapeamento do ano de 1997 e, por isto, as informações são apresentadas em um único mapa.
} 
O segundo procedimento foi unificar as informações das áreas de quadras dos anos 1997/2000 e 2013 em um único mapa. Para isto, utilizou a ferramenta merge, que é capaz de unir duas camadas distintas (neste caso, os mapeamentos dos diferentes anos) em uma única. Este procedimento resultou em um mapa com as informações atualizadas com as quadras de 2013 e em regiões onde não havia informações recentes, o mapa manteve as informações do mapeamento de 1997/2000. O total da área com mapeamento dos anos 1997/2000 é de 352 km² e a área com o mapeamento da área de 2013 é de $766 \mathrm{~km}^{2}$. A imagem a seguir mostra o resultado deste procedimento e identifica as áreas onde foram utilizadas as informações dos anos distintos.

Figura 15: Resultado da Ferramenta Merge - Áreas de quadras do município do Rio de Janeiro anos de 1997/2000 e 2013

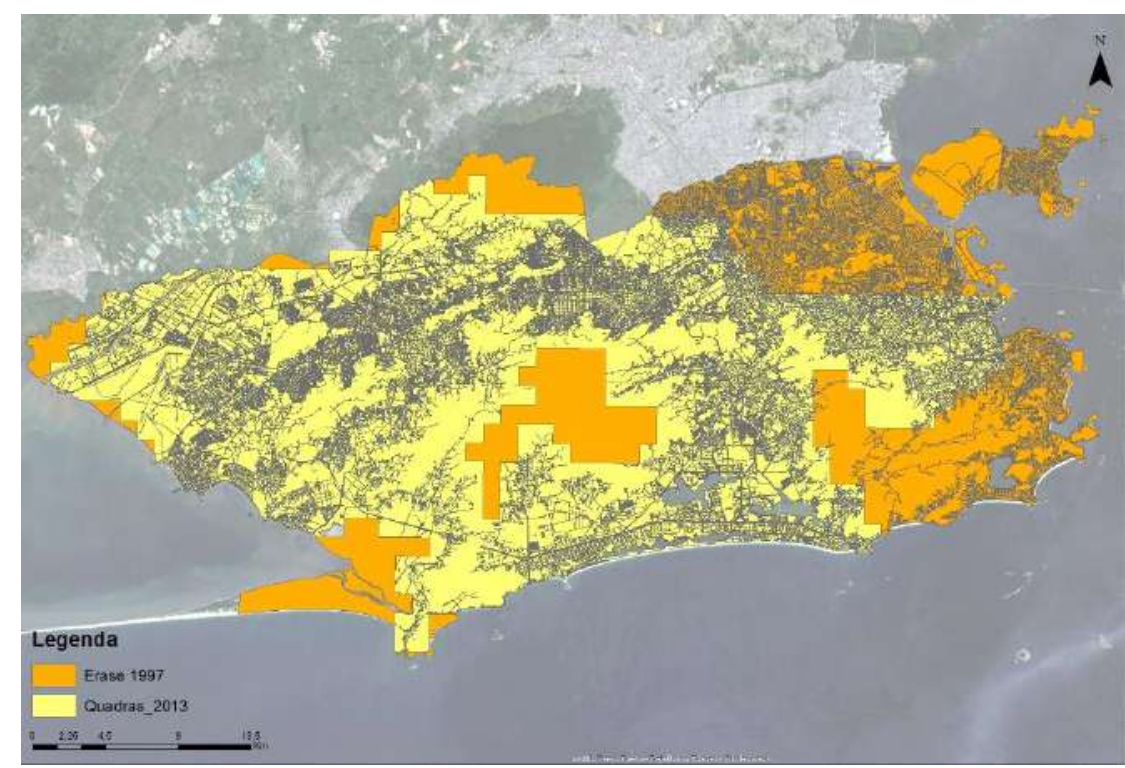

Fonte: Elaboração própria com base em Armazém de Dados IPP

(iii) $3^{\circ}$ Procedimento - Ferramenta Erase

O terceiro procedimento utilizou novamente a ferramenta erase. Desta vez, o recurso de entrada foi a extensão territorial do município do Rio de Janeiro e o recurso a ser sobreposto era o mapa resultado do merge entre os dados de 1997/2000 e 2013. Neste caso, esta prática forneceu as áreas da cidade que não são ocupadas pelas quadras, isto é, as áreas ocupadas por vias. A imagem a seguir apresenta o resultado desta ferramenta. Todos os três procedimentos foram repetidos sete vezes, onde os resultados apresentados foram sempre os mesmos, o que garantiu a confiabilidade do resultado aqui apresentado. 
Figura 16: Resultado 2 da Ferramenta Erase - Áreas de vias do município do Rio de

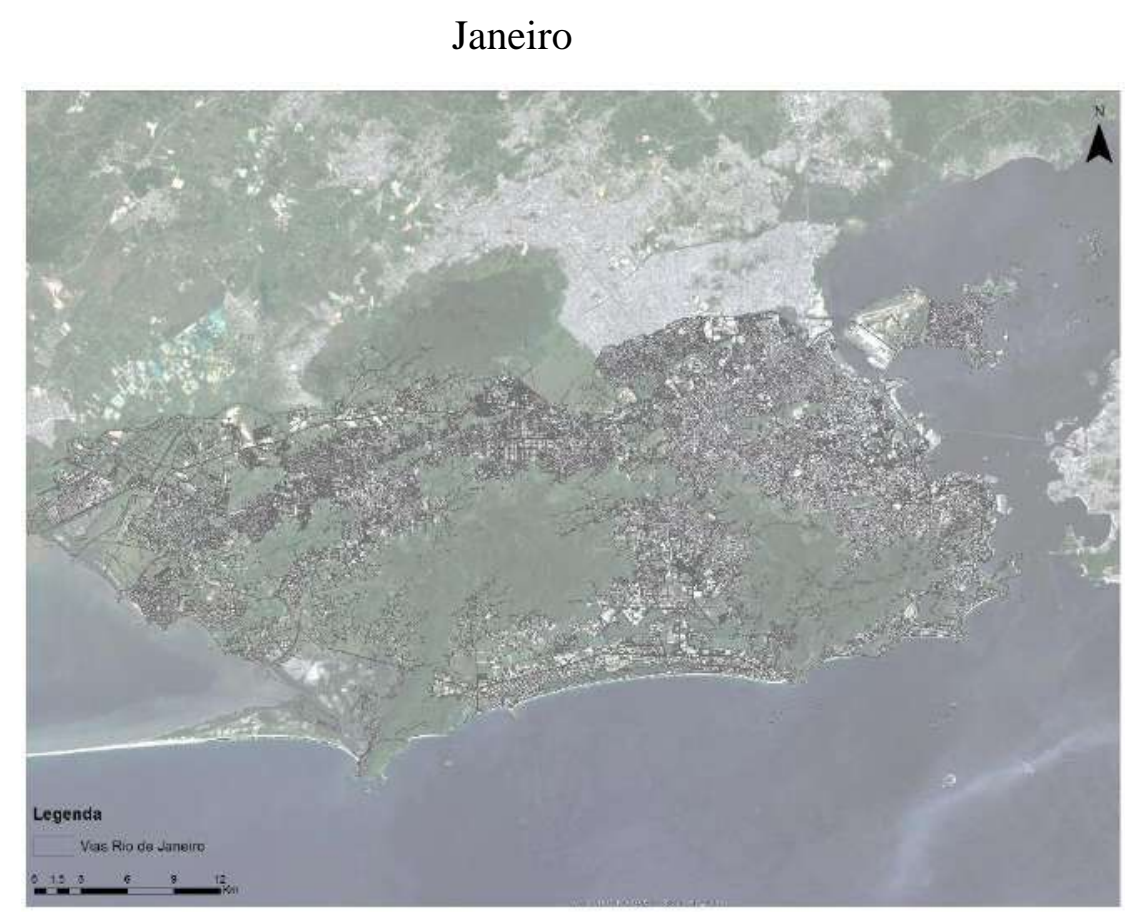

Fonte: Elaboração própria com base em Armazém de Dados IPP

A tabela a seguir apresenta um compilado das informações utilizadas nesta etapa 1. A tabela apresenta também os procedimentos realizados no SIG para a identificação final da área total de vias no município, assim como o propósito de cada um destes procedimentos. 
Tabela 23: Síntese dos procedimentos usados para a identificação das áreas de via no Rio de Janeiro

\begin{tabular}{|c|c|c|}
\hline $\begin{array}{l}\text { Informações } \\
\text { Utilizadas }\end{array}$ & $\begin{array}{c}\text { Mapeamento das áreas de } \\
\text { quadras dos anos 1997/2000 } \\
\text { e mapeamento das áreas de } \\
\text { quadras do ano de } 2013\end{array}$ & $\begin{array}{l}\text { Mapeamentos usados como base para a } \\
\text { identificação das áreas de vias. }\end{array}$ \\
\hline Procedimento 1 & Ferramenta Erase (Figura 14) & $\begin{array}{l}\text { Utilizada para identificar as áreas que não } \\
\text { atualizaram o mapeamento em } 2013\end{array}$ \\
\hline Procedimento 2 & $\begin{array}{l}\text { Ferramenta Merge (Figura } \\
\text { 15) }\end{array}$ & $\begin{array}{l}\text { Utilizada para unificar as informações das } \\
\text { áreas de quadras dos anos de } 1997 / 2000 \text { e } 2013\end{array}$ \\
\hline Procedimento 3 & Ferramenta Erase (Figura 16) & $\begin{array}{l}\text { Utilizada para identificar a área de via total a } \\
\text { partir do mapeamento unificado das áreas de } \\
\text { quadra dos anos } 1997 / 2000 \text { e } 2013\end{array}$ \\
\hline
\end{tabular}

Fonte: Elaboração Própria

\subsection{1.c O cálculo da área total de vias na cidade do Rio de Janeiro}

O cálculo da área de vias urbanas na cidade do Rio de Janeiro, no software ArcGIS 10.2 foi possível devido a ferramenta "Calculate Geometry”. Esta ferramenta fornece a área de todos os polígonos identificados (os polígonos que representam as vias urbanas, neste caso). $\mathrm{O}$ resultado foi que as vias ocupam um total de $113 \mathrm{~km}^{2}$ da cidade do Rio de Janeiro. Tal valor corresponde a aproximadamente 9,3\% do território total. Ainda que este número seja um valor menor do que a média dos países em desenvolvimento apresentadas no capítulo 3, é importante considerar as características geográficas da cidade. Isto é, o território da cidade do Rio de Janeiro apresenta diversos acidentes geográficos como maciços, baias, restingas, etc.

Sendo assim, foi realizado um novo cálculo para caracterizar a área de via da cidade, com base no percentual de área urbanizada da cidade. Para isto, usou-se o mapeamento de uso do solo na cidade, do ano de 2013, disponibilizado pelo IPP. Neste mapeamento, são apresentadas as áreas urbanizadas e áreas não urbanizadas da cidade. Desta informação, obtevese que aproximadamente $640 \mathrm{~km}^{2}$ da cidade do Rio de Janeiro são áreas não urbanizadas, enquanto a área urbanizada é de aproximadamente de $580 \mathrm{~km}^{2}$.

Desta forma, o cálculo da área de vias foi efetuado novamente, desta vez considerando apenas a área construída da cidade. Neste caso, a área de via ocupa um percentual de 
aproximadamente $19,4 \%$ do total. Isto é, dos $580 \mathrm{~km}^{2}$ de área urbanizada na cidade, $113 \mathrm{~km}^{2}$ são destinados a vias urbanas. Resultado similar ao esperado a partir do relatório da UNHABITAT (2013). A figura a seguir apresenta uma comparação entre as áreas não urbanizadas (mapa superior) e as áreas de via (mapa inferior) A tabela apresentada em seguida, sintetiza as informações obtidas nesta etapa do estudo.

Figura 17: Comparação entre áreas não urbanizadas e as áreas de vias no município do Rio de Janeiro

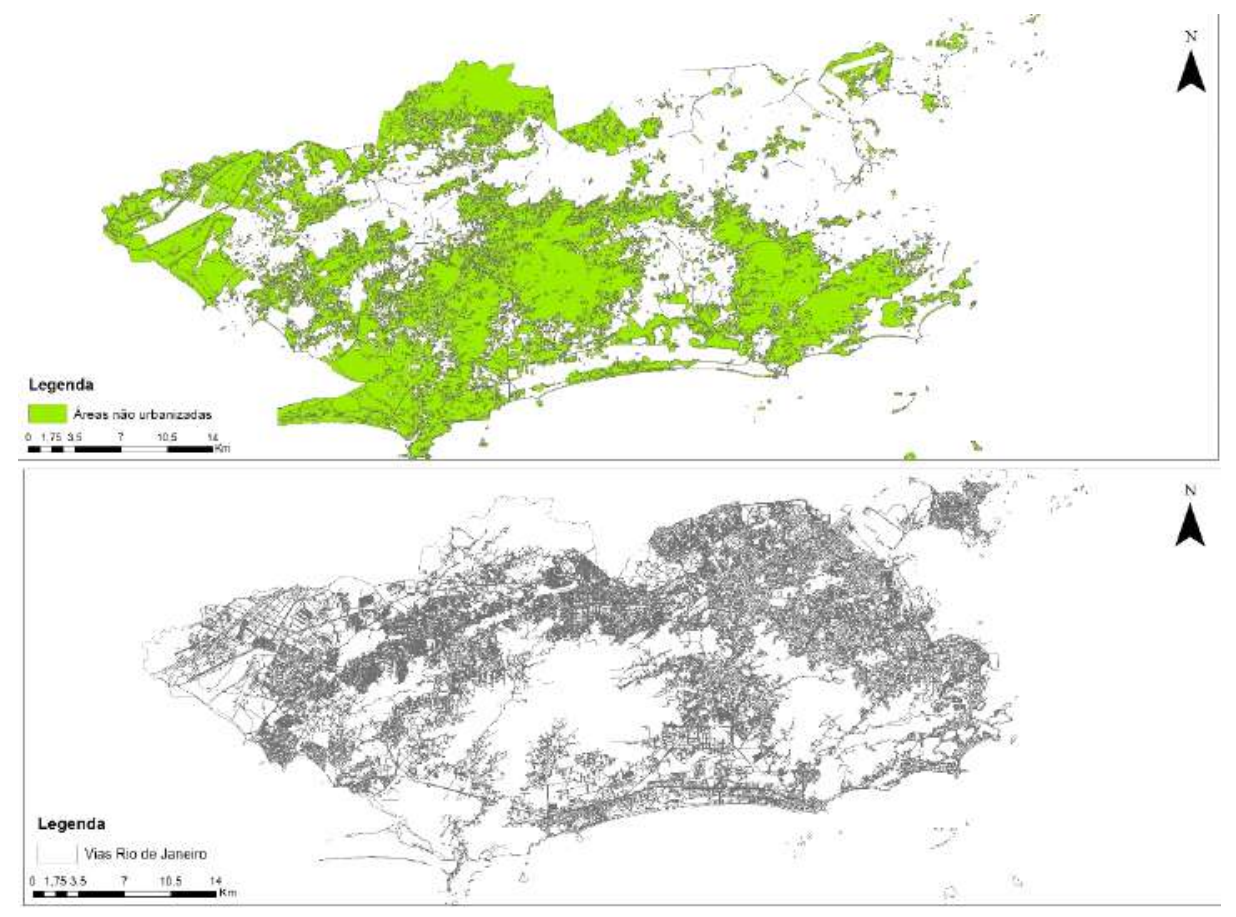

Fonte: Elaboração própria com base em Armazém de Dados IPP

Tabela 24: Síntese dos resultados do estudo de caso sobre o município do RJ

\begin{tabular}{cc} 
Área Total Município RJ & $1210 \mathrm{Km}^{2}$ \\
\hline Área Urbanizada Município RJ & $580 \mathrm{Km}^{2}$ \\
\hline Área de vias no Município do RJ & $113 \mathrm{Km}^{2}$
\end{tabular}

Fonte: Elaboração própria com base em Armazém de Dados IPP 


\subsubsection{Radiação solar absorvida pelas vias no Rio de Janeiro (Etapa 2)}

\subsection{2.a 0 cálculo da radiação solar absorvida e os elementos necessários}

O impacto da infraestrutura urbana do setor de transporte no aquecimento global foi aqui calculado com base no total de radiação solar que as superfícies de via na cidade do Rio de Janeiro absorvem. Isto porque, conforme apresentado no capítulo 2, o aquecimento global é resultado de um desequilíbrio no balanço de radiação terrestre, caracterizado pelo aumento da radiação retida na superfície terrestre. Desta forma, quanto mais radiação uma superfície retém, menor a quantidade que é refletida de volta para a atmosfera, o que incentiva o aumento de temperatura.

Com base nisto, o cálculo do total de radiação absorvida pela área de via na cidade do Rio de Janeiro foi baseado no potencial de albedo das superfícies de concreto e asfalto. Cabe aqui lembrar, que o albedo é o resultado da razão entre a radiação refletida e a radiação incidente, como mostra a equação 1 (Callegare et al, 2016). Desta forma, ao considerar que, do total de radiação incidente, a porcentagem de radiação que não for refletida será absorvida, a partir do potencial de albedo de uma superfície é possível calcular também o total de radiação absorvida pela mesma. Nesta mesma linha, D'Angiolella et al (2001) aponta que a radiação absorvida por um material pode ser calculada conforme mostra a equação 2 a seguir, onde $Q a$ é Radiação absorvida e $r$ é o albedo da superfície.

Equação 1: Equação do Albedo e Fatores Envolvidos

$$
A=R r / R i
$$
A: Albedo
Rr: Radiação refletida
Ri: Radiação incidente
Fonte: Callegare et al, (2016)

Equação 2: Radiação absorvida por uma determinada superfície

$$
Q a=\text { Incidência Solar }(1-r)
$$

Fonte: D'Angiolella et al (2001)

Sendo assim, para calcular a radiação absorvida pela superfície de via no Rio de Janeiro, foram necessárias duas informações principais: (i) a radiação solar incidente e (ii) o potencial de albedo da superfície das vias. A seguir são apresentados separadamente o referencial teórico que baseou os dados usados para determinar as duas variáveis. 


\subsection{2.b Radiação Solar Incidente}

A radiação solar incidente na superfície terrestre é determinada por diversos fatores relacionados a condições atmosféricas e a características como a latitude do local e a posição no tempo (hora do dia e do ano) (Pereira et al, 2006). No caso das condições atmosféricas, destaca-se a participação da atmosfera, que absorve parte da radiação recebida e das nuvens e aerossóis que ao contrário refletem parte desta radiação. Desta forma, ainda que a incidência de radiação global média seja de aproximadamente $342 \mathrm{~W} / \mathrm{m}^{2}$, apenas aproximadamente $198 \mathrm{~W} / \mathrm{m}^{2}$ atingem a superfície terrestre (IPCC, 2007).

É importante considerar que estes dados representam uma média global, e como aqui mencionado, a incidência de radiação solar também varia segundo características geográficas e temporais. Esta variação ocorre, pois, a Terra possui um formato de esfera, o que provoca diferentes durações de incidência solar em algumas regiões e períodos do ano (IPCC, 2007). Segundo o Atlas Brasileiro de Energia Solar (Pereira et al, 2006), as variações mais intensas são nas regiões polares e nos períodos de solstício. O inverso ocorre próximo a linha do equador e durante os equinócios. Ou seja, além da variação oriunda das diferentes condições atmosféricas, a incidência solar será diferente também para cada região da superfície terrestre em determinado período do ano.

No caso brasileiro, as características geográficas de cada região do país apresentam forte influência na variabilidade sazonal da incidência de radiação solar. Segundo Martins et al (2007), as variabilidades sazonais são maiores nas áreas costeiras da região Sul e Sudeste enquanto observa-se um padrão mais estável nas áreas centro-norte do país. No entanto, dado que a maior parte do seu território está localizada relativamente próxima da linha do equador, não se observam grandes variações na duração solar do dia (Pereira et al, 2006 e Martins et al, 2007). Desta forma, ainda que a incidência de radiação solar no país varie conforme as épocas do ano, a média do total diário de irradiação solar é bem uniforme em todo o território (Martins et al, 2007).

Atualmente, diversos estudos já analisam a incidência de radiação solar no Brasil, como é o caso do Atlas Solarimétrico do Brasil (Tiba, 2000) e o Atlas Brasileiro de Energia Solar (Pereira et al, 2006). Estes estudos apresentam o cálculo específico da radiação solar incidente no país em todos seus estados, em diferentes épocas do ano como mostra a figura 18 a seguir. Ressalta-se aqui, que as regiões brasileiras com maior distinção no total médio de irradiação solar global são o litoral dos estados de Santa Catarina e Paraná $\left(177 \mathrm{~W} / \mathrm{m}^{2}\right)$ e a região semiárida do Nordeste brasileiro $\left(270 \mathrm{~W} / \mathrm{m}^{2}\right)$ (Martins et al, 2007). 
Figura 18: Mapas com as médias anual e sazonal do total diário de irradiação solar global no Brasil

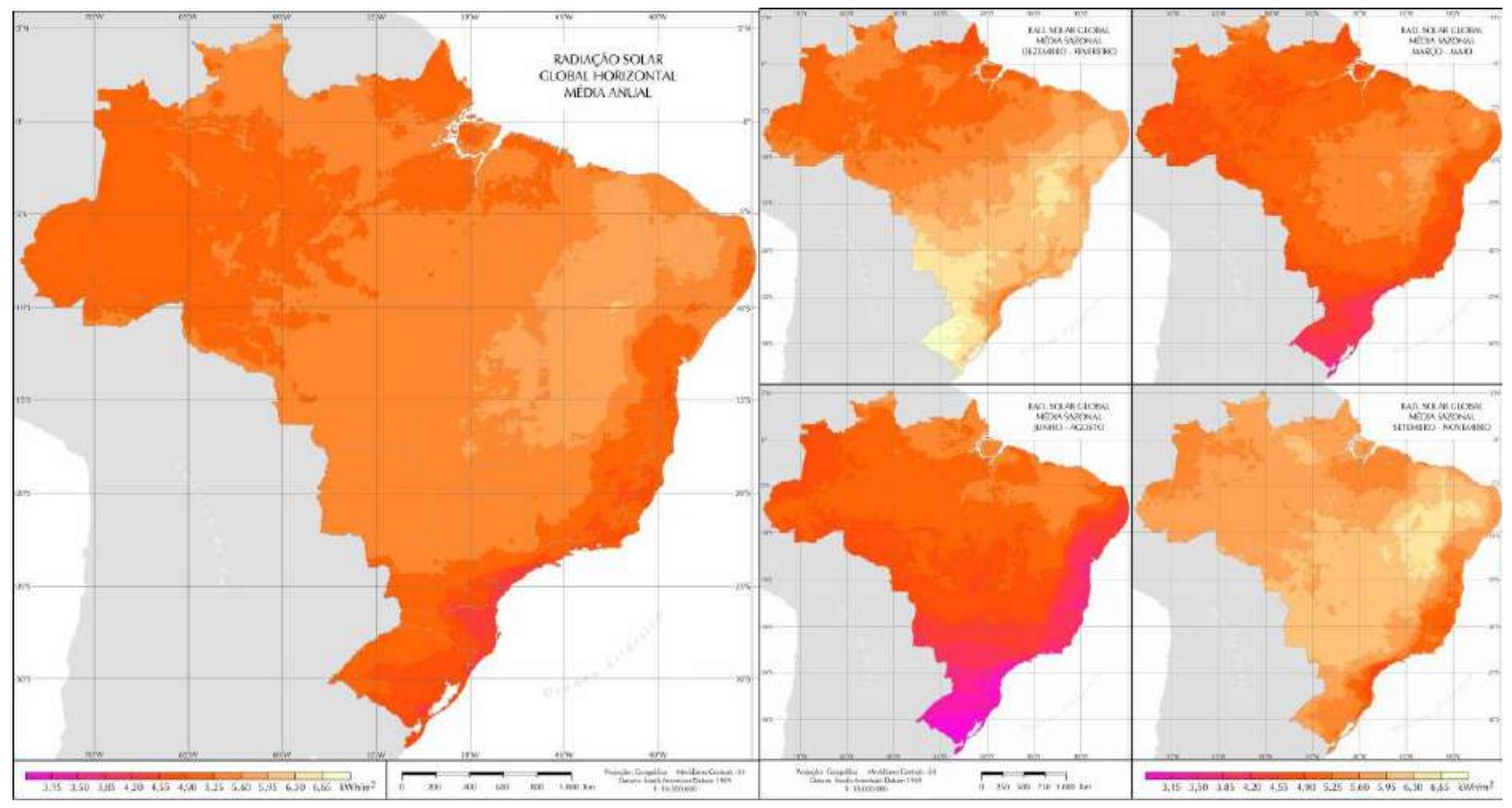

Fonte: Pereira et al (2006)

Estes mapas de irradiação solar também são apresentados pelas publicações mencionadas anteriormente e foram estes mapas que serviram como base para determinar o total de radiação solar incidente na cidade do Rio de Janeiro. Cabe aqui mencionar, que estes estudos têm como principal objetivo a análise do potencial de energia solar do território, e por isso apresentam a incidência de radiação medida em unidade de energia $\left(\mathrm{Wh} / \mathrm{m}^{2}\right)$, diferente da unidade utilizada pelo IPCC para assuntos relacionados ao aquecimento global $\left(\mathrm{W} / \mathrm{m}^{2}\right)$. A tabela a seguir apresenta diferentes valores médios de irradiação solar no Estado do Rio de Janeiro.A partir destes estudos, considerou-se que a incidência de radiação solar média na cidade do Rio de Janeiro é de $215 \mathrm{~W} / \mathrm{m}^{2}$. 
Tabela 25: Valores médios de radiação solar no Estado do Rio de Janeiro Radiação solar global diária - média anual -Rio de Janeiro

\begin{tabular}{cc} 
Atlas Solarimétrico (CRESEB, 2000) & $5160 \mathrm{Wh} / \mathrm{m}^{2}$ \\
\hline Aneel (2002) & 5100 a $5300 \mathrm{Wh} / \mathrm{m}^{2}$ \\
\hline Atlas Brasileiro de Energia Solar (2006) & $5250 \mathrm{Wh} / \mathrm{m}^{2}$ \\
\hline
\end{tabular}

\subsection{2.c Albedo da Superfície}

O albedo do planeta terra é de $30 \%$. Isto significa dizer que a Terra é capaz de refletir em média $30 \%$ da radiação solar que ela recebe. Ainda que a maior parte deste potencial esteja relacionado ao albedo das nuvens, controlar o albedo da superfície terrestre é de extrema importância para o controle da temperatura global. Isto porque, como o IPCC (2007) aponta, uma diminuição de $1 \%$ no albedo planetário é equivalente a dobrar a concentração de gases de efeito estufa na atmosfera, e poderia aumentar a temperatura da superfície em até $1^{\circ} \mathrm{C}$.

Segundo Silva (2005), existem pelo menos quatro fatores que influenciam no albedo de uma superfície (i) a própria condição da superfície; albedos mais altos são encontrados em superfícies lisas, secas e de coloração clara ao passo que superfícies rugosas, úmidas e com coloração escura apresentam albedos mais baixos; (ii) o angulo zenital do sol, o que leva a variações diurnas acentuadas; (iii) o estado do céu, que considera os tipos e quantidade de nuvens; (iv) o ângulo da superfície com a horizontal, particularmente se ele estiver na direção ou distante do sol. A tabela a seguir apresenta a variação do albedo de diferentes tipos de superfície, segundo Alves e Vecchia (2012). 
Tabela 26: Variação de albedo para diferentes superfícies

\begin{tabular}{cc} 
Superfície & Albedo $(\boldsymbol{\%})$ \\
\hline Solo negro e seco (úmido) & $14(8)$ \\
\hline Solo nu & $7-20$ \\
\hline Areia & $15-25$ \\
\hline Florestas & $3-10$ \\
\hline Campos de Cultivo seco & $20-25$ \\
\hline Gramados & $15-30$ \\
\hline Neve recém-caída & 80 \\
\hline Cidades & $14-18$ \\
\hline
\end{tabular}

Fonte: Adaptado Alves e Vecchia (2012)

Como pode ser observado na tabela anterior, o albedo das áreas urbanas é baixo, principalmente quando comparado, por exemplo, ao potencial de reflexão das áreas rurais (Angelini et al, 2015). Tal fato é amplamente reconhecido na literatura científica sobre o tema e como aponta Gartland (2010), o baixo albedo das áreas urbanas ocorre principalmente devido aos materiais de construção usados nas cidades. Destes materiais, destaca-se aqui aqueles usados para a construção das vias urbanas (concreto e asfalto), que como apresentado no capitulo 3, respondem por parte significativa da superfície das cidades, inclusive no caso da cidade do Rio de Janeiro.

O concreto e o asfalto possuem potenciais de reflexão distintos. Segundo Oke (1987) e Kruger (2016), o concreto é capaz de refletir até 30\% mais radiação que o asfalto. No caso das vias urbanas nas cidades brasileiras, o principal material usado para a pavimentação é o asfalto (Nakaruma, 2011). Segundo o autor, no Brasil, a porcentagem de estradas pavimentadas com asfalto é de $90 \%$. Desta forma, o albedo da superfície das vias na cidade do Rio de Janeiro foi baseado no albedo da superfície asfáltica.

O potencial de reflexão considerado para a superfície asfáltica na cidade do Rio de Janeiro foi de $15 \%$. Este valor foi baseado em uma média daqueles encontrados na literatura sobre o tema (tabela 27). Isto porque, ao considerar os diferentes fatores que influenciam o albedo de uma superfície para determinar o albedo específico da cidade do Rio de Janeiro seriam necessárias aplicações que não abrangem o escopo deste trabalho. Não foi encontrado também na literatura científica nenhum estudo que reportasse tal valor. 
Tabela 27: Valores de albedo do asfalto

\begin{tabular}{cc} 
Oke (1987) & $5-20 \%$ \\
\hline Kruger (2016) & $15 \%$ \\
\hline Cueto et al (2015) & $19 \%$
\end{tabular}

Fonte: Elaboração própria com base nos estudos apresentados

\subsubsection{Radiação solar total absorvida pelas vias no Rio de Janeiro (Etapa 3)}

Os resultados das variáveis necessárias para o cálculo do impacto da infraestrutura urbana de transporte usadas neste estudo de caso estão apresentados na tabela 28. Em seguida, são apresentadas as equações que originaram os cálculos que serão aqui apresentados. Cabe mencionar que o albedo da superfície asfáltica e a incidência de radiação solar no Rio de Janeiro, são valores aproximados baseados nas referências apresentadas nas seções anteriores. No tocante as áreas de vida da cidade, o valor foi resultado de um procedimento realizado através do Sistema de Informação Geográfica, com bases em informações disponibilizadas pelo Instituto Pereira Passos (IPP), também apresentado anteriormente.

Tabela 28: Elementos para o cálculo de absorção das vias urbanas na cidade do Rio de Janeiro

Absorção de radiação por uma superfície

(A):

Incidência Solar $(1-r)$

\begin{tabular}{cc}
\hline Incidência solar no Rio de Janeiro (i): & $215 \mathrm{~W} / \mathrm{m}^{2}$ \\
\hline Albedo superfície asfáltica (r): & 0,15 \\
\hline Área de via da cidade do Rio de Janeiro & $113 \mathrm{~km}^{2}$ \\
$(\mathrm{~T}):$ &
\end{tabular}

Fonte: Elaboração própria com base com base nos estudos apresentados 
Equação 3: Equação da absorção de radiação solar pela superfície asfáltica no município do Rio de Janeiro

$$
\begin{gathered}
A=(1-r), \text { ou seja: } \\
\text { Aa }=215(1-0,15)
\end{gathered}
$$

Equação 4: Equação da absorção de radiação solar total pela superfície asfáltica no município do Rio de Janeiro

$$
A=(1-r) * T, \text { ou seja: }
$$

At asfáltica $=215(1-0,15) * 113 \times 10^{6}$

Assim, tem-se que a radiação solar absorvida pela superfície de via no Rio de Janeiro é de aproximadamente $183 \mathrm{~W} / \mathrm{m}^{2}$. Isto significa dizer, que dos $215 \mathrm{~W} / \mathrm{m}^{2}$ de radiação solar recebida esta superfície reflete apenas $32 \mathrm{~W} / \mathrm{m}^{2}$. Ao realizar os cálculos com base na área de vias total na cidade, conclui-se que estas superfícies absorvem um total de $20.701 \mathrm{MW} / \mathrm{m}^{2}$. Isto é, dos $24.321 \mathrm{MW} / \mathrm{m}^{2}$ de radiação solar que as vias urbanas cariocas recebem, elas refletem apenas em torno de $3.620 \mathrm{MW} / \mathrm{m}^{2}$.

\subsection{Considerações finais sobre o impacto da infraestrutura urbana de transportes no Rio de Janeiro e sua contribuição para o Aquecimento Global}

O exemplo da cidade do Rio de Janeiro mostrou o impacto da infraestrutura urbana de transportes no aquecimento global. Este impacto foi calculado a partir do total de radiação solar retida pelas áreas destinadas as vias na cidade. Para isto, foram analisados três elementos principais: a incidência solar na região, o potencial de reflexão da superfície asfáltica e a área total destinada as vias.

A escolha pela cidade do Rio de Janeiro possibilitou uma análise diferenciada principalmente devido às características geográficas da cidade. Isto porque, como foi aqui apresentado, a partir do mapeamento do uso do solo do IPP (IPP, 2013) identificou-se que apenas menos da metade da área total do município (47 \%) é caracterizada como área urbanizada. Desta forma, foi possível evidenciar uma grande diferença entre a área ocupada por vias em relação a área total do município $(9,3 \%)$ e em relação apenas a área total urbanizada $(19 \%)$. 
Pode-se concluir então, que as caracteristicas geográficas do Rio de Janeiro, limitam o cresimento da área de vias urbanas. Por consequinte, esta apresenta uma área total de vias menor do que grande parte das cidades, inclusive aquelas localizadas também em países em desenvolvimento ${ }^{10}$. Tendo em vista que a área total de vias é um fator relevante no impacto da infraestrutura do setor de transportes no aquecimento global, quanto maior a área de via de uma cidade pode-se supor que maior será seu impacto. Neste sentido, a menor área de via urbana permite que a infraestrutura de transportes da cidade do Rio impacte menos no aquecimento global do que cidades como, por exemplo, São Paulo, que possui uma área de vias urbanas de aproximadamente $320 \mathrm{~km}^{11}$.

Ao considerar a mesma incidência de radiação que a cidade do Rio de Janeiro (215 $\left.\mathrm{MW} / \mathrm{m}^{2}\right)$ e o mesmo albedo da superfície asfáltica $(0,15)$, tem-se que a radiação absorvida pelas vias da cidade de São Paulo é de $58.560 \mathrm{MW} / \mathrm{m}^{2}$. Tal valor é significativamente maior que a radiação absorvida pelas vias da cidade do Rio de Janeiro, que é de $20.701 \mathrm{MW} / \mathrm{m}^{2}$. Apesar de esta comparação ser apenas uma aproximação, pois considera a mesma incidência de radiação em ambas as cidades, ela reflete a relevância da área total de vias urbanas no impacto da infraestrutura do setor de transportes no balanço de radiação global.

Como este estudo de caso mostrou, outro fator que influencia o potencial de absorção de radiação pela infraestrutura de vias urbanas é o albedo da superfície. Neste ponto, ressaltase a eficácia das medidas de mitigação relacionadas à prática da geoengenharia, como, por exemplo, a implementação de pavimentos brancos e mais refletivos conforme apresentados por Akbari et al (2008) e Menon et al (2009) no capitulo 2. Estes autores apontam que estas medidas podem aumentar o albedo da superfície asfáltica em aproximadamente 0,1. Desta forma, o albedo da superfície asfáltica aumentaria para 0,25. Neste caso, a exemplo da cidade do Rio de Janeiro, estima-se que deixariam de ser abosrvidos $21,5 \mathrm{MW} / \mathrm{m}^{2}$, o que resultaria em uma redução total de $2.429 \mathrm{MW} / \mathrm{m}^{2}$.

Por fim, acredita-se que o estudo de caso da cidade do Rio de Janeiro, a partir da análise conjunta da incidência de radiação solar, do albedo da superfície asfáltica e da área total de vias na cidade, evidenciou a importância do impacto da infraestrutura de tranportes no aquecimento global. Este estudo de caso ressaltou também a importância das medidas de mitigação

\footnotetext{
${ }^{10}$ Como foi apresentado no relatório da UN-HABITAT (2013), cidades como Nairobi e Lagos que apresentam um pouco mais de $15 \%$ da área da cidade destinadas a ruas.

${ }^{11}$ Para área total de vias na cidade de São Paulo foi usada como base a porcentagem de $21 \%$ de área de vias apontada por Vasoncellos (2006). Considerou-se então, que da área total da cidade de $1.521 \mathrm{~km}^{2}$ (IBGE, 2016), aproximadamente $320 \mathrm{~km}^{2}$ são ocupados por vias.
} 
relacionando-as ao albedo da superfície e a área total de vias urbanas, apresentadas em capítulos anteriores. 


\section{$5 \quad$ Capítulo 5: Considerações Finais}

As mudanças climáticas são uma realidade. $\mathrm{O}$ aquecimento global é um dos efeitos destas mudanças, caracterizado pelo aumento nas temperaturas médias da superfície terrestre ocasionado pelo desequilíbrio no balanço de radiação (IPCC, 2007). Os impactos deste aquecimento são em parte, ainda desconhecidos, devido principalmente a grande complexidade do sistema climático. No entanto, já é consenso entre cientistas que com o aquecimento global a vulnerabilidade dos assentamentos humanos aumentará. Isto ocorrerá através, por exemplo, de fenômenos como a elevação do nível do mar, períodos de maior calor e a propagação de doenças (IPCC, 2014c).

Destaca-se então, a dupla relação entre o aquecimento global e as cidades. Ao passo que são extremamente vulneráveis aos impactos do aquecimento global, elas contribuem diretamente para o desequilíbrio do sistema climático. As emissões de gases de efeito estufa são consideradas a principal fonte de impacto das cidades nas mudanças climáticas. Segundo Marcotullio et al (2013) as cidades respondem por um total entre 38\% e $48 \%$ das emissões totais de $\mathrm{GEE}^{12}$. Tais valores são ainda mais impactantes ao considerar que, apesar de concentrar atualmente a maior parte da população mundial, as áreas urbanas correspondem por apenas $1,2 \%$ da superficie terrestre (Akbari, 2008; ONU, 2014). Acredita-se que a perspectiva de crescimento da população urbana nos próximos anos provocará um aumento do consumo de energia e das emissões de GEE, agravando ainda mais as mudanças climáticas.

Ressalta-se aqui a grande participação do setor de transportes urbano, responsável por aproximadamente $1 / 3$ da utilização final da energia global, das quais $71 \%$ são provenientes de combustíveis fósseis não renováveis, com alto nível de emissão de GEE (IEA, 2008). Desta forma, acredita-se que o crescimento da população urbana e o consequente aumento na demanda por transportes irá implicar também no crescimento dessas emissões. Isto porque, nos dias de hoje, grande parte dos sistemas de transportes urbanos mundiais são baseados no modo rodoviário e, a menos que haja uma mudança nos padrões do uso de energia, estima-se que o consumo de energia do setor de transportes em 2030 será $80 \%$ maior do que o atual (IPCC, 2014b).

O impacto das cidades no aquecimento global atualmente está sendo discutido também sobre uma nova perspectiva, a de sua infraestrutura urbana. Materiais urbanos comuns possuem

\footnotetext{
${ }^{12}$ Como foi apresentado no capítulo 2 deste trabalho, este estudo analisou as emissões com base no ano de 2000 e considerou apenas cidades com mais de 50.000 habitantes. Foram desconsideradas emissões da queima de biomassa em grande escala e as emissões de aviação e navegação que ocorrem sobre os oceanos.
} 
um baixo albedo, isto é, uma baixa capacidade de refletir a radiação solar incidente. Tem-se que as áreas urbanas refletem, em média, 14-18\% da radiação incidente, enquanto o albedo médio terrestre é de 30\%. Ou seja, os centros urbanos retem uma porcão maior de radiação solar do que a média global. A radiação solar retida na superfície é transformada em calor, o que provoca o aquecimento das temperaturas na superfície terrestre.

Apesar de ainda não muito disseminado, pode-se considerar que este tema vem ganhando importância na literatura científica internacional. Isto porque, como aponta Akbari (2008), o crescimento da população urbana poderá acarretar em uma duplicação das áreas ocupadas por centros urbanos, o que implicaria em um crescimento significativo no impacto da sua infraestrutura urbana nas mudanças climáticas. Desta forma, atualmente existem diversos modelos climáticos que analisam uma visão mais completa do papel das cidades no aquecimento global e, por isso, consideram o impacto da cobertura das superfícies urbanas no balanço de radiação terrestre.

Nesta linha, este trabalhou buscou contribuir com uma perspectiva mais ampla do impacto do setor de transportes nas mudanças climáticas. Para isto, analisou o impacto da sua infraestrutura urbana no balanço de radiação terrestre e apresentou também possíveis medidades de mitigação a estes impactos. Para discutir esta nova perspectiva do impacto do setor de transportes no aquecimento global, o estudo partiu de duas premissas, reafirmadas pela literatura científica no decorrer do trabalho.

A primeira delas é que o aquecimento global é um fenômeno provocado pelo desequilíbrio no balanço de radiação terrestre. Desta forma, atividades que influenciem neste equilíbrio influenciam também no aquecimento global. A segunda premissa é referente aos materiais comumente usados na infraestrutura urbana de transportes, que possuem uma capacidade de refletir radição considerada baixa, menor do que a média da superfície terrestre e por isso impactam no equilíbrio do balanço de radiação terrestre.

Para investigar o impacto da infraestrutura urbana de transportes no aquecimento global o estudo sugeriu duas hipoteses principais: (i) a escolha dos materiais usados para a construção da infraestrutura urbana de transportes é capaz de minimizar o impacto deste setor no aquecimento global; (ii) a melhor forma de disposição urbana é capaz de influenciar a área construída destinada ao setor de transportes é capaz de minimizar os impactos deste setor no aquecimento global.

Acredita-se que ambas as hipóteses foram comprovadas ao longo do trabalho. A escolha de materiais urbanos mais refletivos é capaz de aumentar a capacidade da infraestrutura urbana 
de transportes de refletir radiação. Desta forma, apesar de estes materiais possuírem uma capacidade de refletir radiação significativamente inferior à média global, a escolha de materiais mais refletivos possibilitaria uma redução nesta diferença. Ressalta-se a importância destas medidas de mitigação ao considerar que a infraestrutura urbana de transportes atualmente representa em média, no mínimo, entre 10-20\% das áreas das cidades.

No tocante a segunda hipótese, esta foi abordada a partir da capacidade do setor de transportes de direcionar a forma de desenvolvimento das cidades. Ou seja, grandes partes das cidades são dispersas, baseadas no modo de transporte rodoviário que, principalmente quando não combinado a políticas de uso do solo eficientes, acarretam no espraiamento urbano. Nesta linha, o estudo destacou a importância de conectar medidas de planejamento urbano a políticas de transportes como forma de mitigar o impacto da infraestrutura urbana de transportes no aquecimento global.

Foram apresentadas estratégias que relacionam transporte e uso do solo, principalmente através do desestímulo do transporte motorizado individual. Este trabalho destacou duas delas, o Desenvolvimento Orientado ao Transporte Sustentável e o Gerenciamento de Demanda por Viagem. Ressalta-se que, ainda que nenhuma delas apresente como objetivo a mitigação do impacto da infraestrutura urbana de transportes no aquecimento global, estas auxiliam no controle da expansão desta infraestrutura, e por isso são consideradas medidas eficazes.

Para facilitar o entendimento desta pesquisa, foi realizada uma análise complementar do impacto da infraestrutura do setor de transportes no aquecimento global a partir do estudo de caso da cidade do Rio de Janeiro. A escolha da cidade do Rio de Janeiro foi baseada no fato desta ser a capital de um estado com ampla representatividade econômica, localizada em um país em desenvolvimento. Neste estudo, a partir da análise das áreas de vias na cidade, foi calculado o total de radiação absorvida por estas superfícies. Sendo assim, com base da absorção total da radiação das áreas de vias, foi possível caracterizar o impacto desta no aquecimento global.

Para caracterizar o impacto da infraestrutura urbana de transportes no aquecimento global da cidade do Rio de Janeiro, o estudo considerou três principais fatores: a radiação solar da região; o potencial do material utilizado na infraestrutura urbana de transportes de refletir radiação (albedo) e a área total de vias na cidade. Devido principalmente as caraterísticas geográficas da cidade, conclui-se que o impacto da infraestrutura de transportes da cidade do Rio de Janeiro pode ser considerado inferior do que o impacto em outras cidades, como São Paulo. 
O estudo de caso abordou também o impacto no aquecimento global de medidas de mitigação relacionadas ao aumento do potencial de reflexão da infraestrutura urbana de transporte. Estas técnicas fazem parte de um conjunto de práticas de combate às mudanças climáticas, chamado de geoenharia. Neste sentido, o estudo apresentou o efeito esperado no total de radiação solar absorvida por estas superficies caso haja um aumento no albedo das áreas de vias.

Destaca-se a contribuição do estudo de caso ao evidenciar a importância das medidas de mitigação que aqui foram apresentadas. Isto é, as práticas de mitigação relacionadas ao transporte e uso do solo mais sustentáveis assim como a implantação de materiais refletivos influenciam diretamente nas variáveis de área total de vias e albedo da superfície. Ou seja, as medidas de mitigação apresentadas abordam duas variáveis que contabilizam o impacto da infraestrutura urbana de transportes no aquecimento global.

Por fim, com base no referencial teórico apresentado e discutido neste estudo, assim como no estudo de caso realizado, este trabalho mostrou que as superficies urbanas da infraestrutura de transportes influenciam diretamente o balanço de radiação do sistema climático. Conclui-se, portanto, que as superfícies urbanas da infraestrutura de transporte contribuem diretamente para o aquecimento global.

No tocante as limitações deste trabalho, destaca-se inicialmente que ele não aborda os impactos ambientais oriundos da elaboração da sua infraestrutura propriamente dita. Isto é, não contabiliza, por exemplo, os impactos da matéria prima utilizada, do consumo de água e energia, as emissões de $\mathrm{CO}_{2}$ relacionadas ao processo produtivo e a produção de resíduos. Neste sentido, para que haja uma análise completa do impacto da infraestrutura do setor de transportes no aquecimento global, recomendam-se pesquisas futuras que relacionem ambas as fontes de impacto.

Este trabalho também apresentou limitações relacionadas ao cálculo dos benefícios proporcionados pelas medidas de mitigação oriundas da alteração dos materiais urbanos. Apesar de apontar o benefício significativo destas práticas de mitigação na literatura científica sobre o tema, o estudo não consegue contabilizar este benefício em temperatura. Desta forma, percebe-se uma dificuldade de quantificar estes melhoramentos em uma linguagem usual, capaz de facilitar o entendimento quando comparado a outras práticas de mitigação.

Por fim, considera-se como principal limitação desta pesquisa a ausência de um cálculo acerca dos benefícios de mitigação associados às políticas de Gerenciamento de Demanda de Viagem e Desenvolvimento Orientado ao Transporte. Tem-se que, devido a incentivarem, por 
exemplo, o desestímulo do transporte individual motorizado, o uso de transporte público e modos ativos de mobilidade, estas políticas diminuem a necessidade da expansão da infraestrutura urbana de transportes. No entanto, ainda não é possível transferir esses benefícios para uma escala numérica. Isto é, não é possível determinar ainda qual a área total que deixaria de ser construída. Nesse sentido, ao passo que não se sabe a área de infraestrutura urbana de transportes que deixaria de ser implantada, não é possível quantificar seus benefícios ao aquecimento global.

Com base no material apresentado ao longo deste trabalho, considera-se que este estudo cumpriu com o seu objetivo. Isto é, evidenciou a participação da infraestrutura urbana de transportes no aquecimento global. Desta forma, o trabalho mostrou que o impacto do setor de transportes no aquecimento global é maior do que aquele contabilizado principalmente através do consumo de energia e das emissões de gases de efeito estufa.

Ao destacar que este impacto tende a se tornar cada vez mais significativo ao considerar o crescimento dos centros urbanos, o trabalho destaca a necessidade de a comunidade acadêmica aprofundar o conhecimento acerca do impacto da infraestrutura urbana no aquecimento global assim como das suas possíveis alternativas de mitigação. 


\section{REFERÊNCIAS BIBLIOGRÁFICAS}

AGÊNCIA NACIONAL DE ENERGIA ELÉTRICA (2012). Energia Solar do Brasil. In: AGÊNCIA NACIONAL DE ENERGIA ELÉTRICA. Atlas de Energia Elétrica no Brasil. Brasília : ANEEL, 2002, cap. 3.

AKBARI, Hashem et al. Cool Surfaces and shade trees to reduce energy use and improve air quality in urban areas. Solar Energy, v. 70, n. 3, p. 295-310, 2001. Disponível em: <http://www.coolrooftoolkit.org/wpcontent/uploads/2012/04/20120127190624231.pdf>. Acesso em 17 out. 2016.

AKBARI, Hashm; ROSE, L. Shea; TAHA, Haider. Analyzing the land cover of an urban environment using hihgresolution orthophotos. Landscape and urban planning, v. 63, n.1, p. 1-14, mar. 2003. Disponível em: <http://www.sciencedirect.com/science/article/pii/S0169204602001652>. Acesso em 15 set 2016.

AKBARI, Hashem; Menon, Surabi; Rosenfeld, Arthur. Global Cooling: Effect of Urban Albedo on Global Temperature. In: 2nd PALENC \& 28th AIVC Conference on Building Low Energy Cooling and Advanced Ventilation Technologies in the 21st Century, 2007. Disponível em: < http://www.inive.org/members_area/medias/pdf/Inive\%5CPalencAIVC2007\%5CVolume1\%5CPalencAI VC2007_002.pdf>. Acesso em 7 ago. 2016.

AKBARI, Hashem; ROSE, L Urban Surfaces and heat island mitigation potentials. Journal Human-Environment, vol. 11, n. 2, p. 85-101, jan. 2008. Disponível em: <: https://www.researchgate.net/publication/255203530> Acesso em 13 mai. 2016.

AKBARI, Hashem; MENON, Surabi; ROSENFELD, Arthur. Global cooling: Increasing world-wide urban albedos to offset CO2. Climatic Change. v, 95. n, 3-4, p.1-12, jun. 2009. Disponível em:< http://www.energy.ca.gov/2008publications/CEC-999-2008-020/CEC-999-2008-020.PDF>. Acesso em 7 set 2016.

ALCOFORADO, Maria João et al. Alterações climáticas e desenvolvimento urbano. Série Política de Cidades, Lisboa: Direcção Geral do Ordenamento do Território e Desenvolvimento Urbano, 2009.

ALVES, L. D. Elis; VECCHIA, S. A. Francisco. Influência de diferentes superfícies na temperatura e no fluxo de energia: um ensaio experimental. Ambiência - Revista do Setor de Ciências Agrárias e Ambientais, v. 8, n. 1, p. 102- 111, abr./2012.

AMORIM, W.V. A produção social do espaço urbano em Londrina - PR: a valorização imobiliária e a reestruturação urbana. 2011. Dissertação (Mestrado em Geografia) - Faculdade de Ciências e Tecnologia/Unesp, Presidente Prudente.

ANCHANTE, T. Jayme. Orientação de Políticas de combate ao congestionamento. 2014. 65 f. Monografia (Graduação em Economia) - Escola de Economia, Universidade Federal do Rio Grande do Sul, Porto Alegre.

ANGELLINI, P. Lucas et al. Relação entre albedo e temperatura da superfície estimados por sensoriamento remoto na área urbana de Cuiabá, Mato Gosso. In: SIMPÓSIO BRASILEIRO DE SENSORIAMENTO REMOTO, XVII, 2015. João Pessoa: INPE, 2015. Disponível em: 〈http://www.dsr.inpe.br/sbsr2015/files/p0377.pdf>. Acesso em 22 jul. 2016.

ARTAXO, Paulo. Equilíbrio Radioativo Terrestre (s.d.). Disponível em: <http://www.mudancasclimaticas.andi.org.br/node/660>. Acesso em mai./2016.

ATLASBRASIL. Atlas do Desenvolvimento Humano do Brasil. Disponível em $:<$ http://www.atlasbrasil.org.br/2013/>. Acesso em 13 out. 2016.

AZEVEDO, Tasso. Uma lacuna de 8 Giga toneladas. Planeta Sustentável. Disponível em: <http://planetasustentavel.abril.com.br/blog/blog-do-clima/2013/11/page/9/ Acesso: 15 ago. 2016. 
BALASSIANO, R. Mobilidade Urbana no Âmbito da Economia Verde. Coleção de estudos sobre diretrizes para uma economia verde no Brasil. Rio de Janeiro: Fundação Brasileira para o Desenvolvimento Sustentável, 2012.

BANCO INTERAMERICANO DE DESENVOLVIMENTO (BID). Guia prático: Estacionamento e políticas de gerenciamento de mobilidade (GDM) na América Latina. Nova Iorque, 2013. 104 p.

BARNETT, Tim P. et all. Detection and Attribution of Recent Climate Change: A Status Report. Bulletin of the American Meteorological Society, v. 80, n. 12, jul 1999. Disponível em: https://www.gfdl.noaa.gov/bibliography/related_files/barnett9901.pdf. Acesso em 12 mai. 2016.

BARRY, Roger G.; CHORLEY, Richard J. Atmosfera, Tempo e Clima. 9 ed. Porto Alegre: Bookman, 2013.

BELO HORIZONTE. Prefeitura Municipal de Belo Horizonte. Inventário Municipal de Emissões de Gases de Efeito Estufa. Belo Horizonte, 2015. 119 p.

BIATO, Márcia Fortuna. -Quadro das Nações Unidas sobre Mudança do Clima. Revista de Informação Legislativa, v. 42, n. 166, abr 2005. Disponível em: < http://www2.senado.leg.br/bdsf/item/id/572> . Acesso em 8 mai. 2016

BOUNDY, Robert; DAVIS, C. Stacy; DIEGEL, W. Susan. Transportation Energy Data book. Tennessee: Oak Ridge National Laboratory, 2011.

BRASIL, INDC. Pretendida contribuição nacionalmente determinada para consecução do objetivo da convençãoquadro das nações unidas sobre mudança do clima. Disponível em:< http://www.itamaraty.gov.br/images/ed_desenvsust/BRASIL-iNDC-portugues.pdf>. Acesso em 13 ago. 2016.

BROADDUS, Andrea; LITMAN, Todd; MENON, Gopinath. Gestion de la demanda de Transporte: Documento de Entrenamiento. Eschborn: GTZ. 2009

CALLEGARE, O. Andyara et al. Estudos sobre o albedo em diferentes tipos de superfície. Energias Renováveis, Florianópolis, 2016.2 Disponível em: $<$ https://energiasrenovaveisunisanta.files.wordpress.com/2016/03/estudo-sobre-o-albedo-em-diferentestipos-de-superfc3adcie.pdf>. Acesso em 18 set. 2016.

CÂMARA, Gilberto et al. Análise Espacial e Geoprocessamento. In: DRCUK, S.; CARVALHO, M.S.; CÂMARA G.; MONTEIRO, A.V.M. (eds) Análise Espacial de Dados Geográficos. Brasília, Editora: EMBRAPA, 2004, cap. 1 .

CAMPRA, Pablo et al. Surface temperature cooling trends and negative radiative forcing due to land use change toward greenhouse farming in southeastern Spain. Journal of Geophysical Research, v. 113, n. D18, p. 110, set. 2008. Disponível em:< http://onlinelibrary.wiley.com/doi/10.1029/2008JD009912/pdf >. Acesso em 25 ago 2016 .

CEPAC (Centro de Excelência em Pesquisa sobre Armazenamento de Carbono). Causas da Mudança do Clima s.d, 49 p.

CEVERO, Robert. Transit-oriented development's ridership bonus: A product of self-selection and public policies. Environment and Planning, vol. 39, n. 9, p. 2068-2085, 2007. Disponível em: <http://citeseerx.ist.psu.edu/viewdoc/download?doi=10.1.1.352.5399 >. Acesso em 17 out. 2016.

CHAPMAN, Lee, 2007. Transport and climate change: a review. Journal of Transport Geography, v. 15, n. 5, p. 354-367, $\quad$ set $2007 . \quad$ Disponível em: https://www.boku.ac.at/fileadmin/_/nachhaltigkeit/Klimafreundliche_Arbeitsmobilit\%C3\%A4t/Chapman _2007_Transport_and_climate_change_a_review.pdf>. Acesso em 19 out 2016.

COSTA, Paulo O. Resposta político-econômica às mudanças climáticas: origens, situação atual e incertezas do mercado de créditos de carbono, 2004. 128 f. Dissertação (Mestrado em Administração) - Escola de Administração, Universidade Federal da Bahia, Salvador. 
CROWLEY, Thomas J. Causes of Climate Change over the past 1000 years. Science, v. 289, n. 5477, pp. 270277, jul. 2014. Disponível em:< https://www.ncbi.nlm.nih.gov/pubmed/10894770>. Acesso: 1 set. 2016.

CRUZ, Isolina; CAMPOS, B. Vânia. Sistemas de Informações Geográficas aplicados a análise espacial em transportes, meio ambiente e ocupação do solo. In: Rio de Transportes, III, 2005, Rio de Janeiro. Anais eletrônicos... Rio de Janeiro: IME, 2005. Disponível em: <http://aquarius.ime.eb.br/ webde2/prof/vania/pubs/(15)SIG-AE2.pdf〉. Acesso em 14 jul. 2016.

CUETO, G. Rafael et al. Parameterization of net radiation in na arid city of northwestern Mexico. Atmósfera, [s.1.] v. 28, n. 2, p. 71-82, jan 2015. Disponível em: 〈http://www.scielo.org.mx/pdf/atm/v28n2/v28n2a1.pdf〉 Acesso em 04 nov. 2016

CUNHA, B. Ana. Prefeito apresenta o programa Rio Resiliente. Prefeitura da Cidade do Rio de Janeiro, 22, jan. 2015. Disponível em: <http://www.rio.rj.gov.br/web/guest/exibeconteudo?id=5173167>. Acesso em 28 set. 2016.

D'AGOSTO, Marcio. Eficiência e tecnologia no transporte de massa e transporte individual. In: PINHEIRO, C. Armando; FRISCHTAK, Cláudio (Org.). Mobilidade Urbana: Desafios e Perspectivas para as Cidades Brasileiras. Rio de Janeiro: Elsevier: FGV/IBRE, 2015. Cap 6

D'ANGIOLLA, G. et al. Radiação: Estudos das características e suas aplicações no Recôncavo Baiano. In: CONGRESSO BRASILEIRO DE AGROMETEOROLOGIA, 12., 2001, Fortaleza. Anais., Fortaleza: Sociedade Brasileira de Agrometeorologia/Fundação Cearense de Meteorologia, 2001.

DODMAN, David. Blaming cities for climate change? An Analysis fo urban greenhouse gas emissions inventories. Environment \& Urbanization. v. 21, n. 185, abr, 2009. Disponível em:< http://eau.sagepub.com/content/21/1/185.full.pdf+html>. Acesso em 21 set. 2016

EMBARQ BRASIL. Dots Cidades - Manual de Desenvolvimento Urbano Orientado ao Transporte Sustentável. 2014.

EUA, INDC. U.S. Cover Note INDC and Acoompanying Information. Disponível em: <http://www4.unfccc.int/Submissions/INDC/Published\%20Documents/United\%20 >. Acesso em 13 ago. 2016.

FUNDAÇÃO CEPERJ. Anuário Estatístico do Rio de Janeiro (2013). Disponível em: <http://www.ceperj.rj.gov.br/ceep/anuario2013/ApresentacaoDemografiaIndicadores.html>. Acesso em 13 out. 2016

FÓRUM RIO. Mapa da Desigualdade: 21 indicadores sobre sete temas-chave da realidade metropolitana do Rio de Janeiro. Disponível em: <http://www.forumrio.org/mapas/mapa-desigualdade/>. Acesso em 27 ago. 2016.

GARCIAS, M., Carlos; SILVA, M. Consuelo. Meio Urbano e mudanças climáticas - estudo de caso do município de Castro, PR Revista de pesquisa em arquitetura e urbanismo. 2011. ponível em: < http://www.iau.usp.br/revista_risco/Risco14-pdf/02_art03_risco14.pdf >. Acessi em 7 jun 2016.

GODOY, Sara; PAMPLONA, João Batista. Protocolo de Kyoto e os países em desenvolvimento. Pesquisa e Debate, v. 18, n. 2(32), ago. 2007.

GOMES, Marco P. Protocolo de Kyoto: Origem. Conjuntura Internacional. 2005. Disponível em: <http://www.pucminas.br/imagedb/conjuntura/CNO_ARQ_NOTIC20050829120850.pdf〉. Acesso em 19 out. 2016.

GOMIDE, A. Alexandre; MORATO, Renato. Instrumentos de desestímulo ao uso do transporte individual motorizado: Lições e Recomendaçoes. Sâo Paulo: Instituto de Energia e Meio Ambiente, 2011.

GARTLAND, Lisa. Ilhas de calor: Como mitigar zonas de calor em áreas urbanas. São Paulo: Oficina de textos, 2010. 
GUERREIRO, Almicar. A Matrizde Transporte e o Desenvolvimento Sustentável. UNIABEU, v.8, n.18, São Paulo, 2012.

HEBBERT, Michael; JANKOVIC, Vladimir. Cities and Climate Change: The Precedents and Why They Matter. Urban Studies - Special Issue, v. 50(7), p. 1332-1347, mai. 2013. Disponível em:< http://usj.sagepub.com/content/50/7/1332.full>. Acesso em 13 out. 2016

IEA. World Energy Outlook, Paris, 2008.

INSTITUTO BRASILEIRO DE GEOGRAFIA E ESTATÍSTICA (IBGE). Infográficos Cidades. Disponível em:< http://www.cidades.ibge.gov.br/xtras/home.php> . Acesso em 13 out. 2016.

INSTITUTO DE POLITICAS DE TRANSPORTE E DESENVOLVIMENTO. Padrão de Qualidade TOD v2.0. Rio de Janeiro, 2013.78 p.

INSTITUTO DE POLITICAS DE TRANSPORTE E DESENVOLVIMENTO. Menos cajones, más ciudad: El estacionamiento en la ciudad de méxico. México, 2014. 97 p.

IPCC. Summary for Policymakers, In: Climate Change 2007: The Physical Science Basis. Contribution of Working Group I to the Fourth Assessment Report of the Intergovernmental Panel on Climate Change. Cambridge, 2007.

IPCC. Appendix I: Glossary. In: Climate Change 2007: The Physical Science Basis. Contribution of Working Group I to the Fourth Assessment Report of the Intergovernmental Panel on Climate Change. Cambridge, $2007 \mathrm{~b}$.

IPCC. Anthropogenic and Natural Radiative Forcing. In: Climate Change 2013: The Physical Science Basis. Contribution of Working Group I to the Fifth Assessment Report of the Intergovernmental Panel on Climate Change. Cambridge, 2013.

IPCC. Human Settlements, Infrastructure and Spatial Planning. In: Climate Change 2014: Mitigation of Climate Change. Contribution of Working Group III to the Fifth Assessment Report of the Intergovernmental Panel on Climate Change. Cambridge e Nova York. 2014a

IPCC. Transport. In: Climate Change 2014: Mitigation of Climate Change. Contribution of Working Group III to the Fifth Assessment Report of the Intergovernmental Panel on Climate Change. Cambridge e Nova York, $2014 \mathrm{~b}$.

IPCC. Summary for Policymakers, In: Climate Change 2014, Mitigation of Climate Change. Contribution of Working Group III to the Fifth Assessment Report of the Intergovernmental Panel on Climate Change, Cambridge e Nova York, 2014c.

INSTITUTO MUNICIPAL DE URBANISMO PEREIRA PASSOS (IPP). Mapoteca - Uso do solo município do Rio de Janeiro (2013). Disponível em: http://pgeo/amdpgint.asp?gtema=12. Acesso em ago 2016.

JO, J.H. et al. Sustainable urban energy: Development of a mesoscale assessment model for solar reflective roof technologies. Energy Policy,v. 38, ed. 12, p. 7951-7959. Disponível em: < 10.1016/j.enpol.2010.09.016>. Acesso em 25 out. 2016 .

JURAS, M. G. Ilidia. Estudo sobre algumas técnicas de geoengenharia para reduzir o Aquecimento Global. Câmara dos Deputados: Área XI Maio Ambiente e Direito Ambiental, Organização Territorial, Desenvolvimento Urbano e Regional. Nov. 2010, 9 p. Disponível em:< http://www2.camara.leg.br/documentos-e-pesquisa/publicacoes/estnottec/areas-daconle/tema14/2010_3958.pdf>. Acesso em 15 nov. 2016

KAARSBERG, T. and AKBARI, Hasen. Cool roofs cool the plant. Home Energy, vol. 38-41, set. 2006. Diponível em:< http://www.energy.ca.gov/2007publications/CEC-999-2007-034/CEC-999-2007-034.PDF>. Acesso em 24 ago. 2016.

KAHN, R. Suzana; AZEVEDO, Tasso. Revista do Clima: Um novo tempo. 2 ed. [S.d]. p. 14-16. 
KRUGER, L. Eduardo; GONZALEZ, G. Dominique. Impactos da alteração no albedo das superfícies no microclima e nos níveis de conforto térmico de pedestres em cânions urbanos. Ambiente construído, vol. 16, n. 3, p. 89-106, set. 2016. Disponível em: 〈http://dx.doi.org/10.1590/s1678-86212016000300094> Acesso em 3 out 2016.

LAGO, André A. C. Conferências de Desenvolvimento Sustentável. Brasília: FUNAG, 2013

LENTON, M. Tim, VAUGHAN, Naomi. The radiative forcing potential of different climate geoengineering options. Atmospheric Chemistry and Physics Cycle, vol. 15, n. 9, p. 891-908, jan. 2009. Disponível em: <http://www.atmos-chem-phys.net/9/5539/2009/acp-9-5539-2009.pdf>. Acesso em 1 set. 2016.

LEVINSON, Ronnen et al. Inclusion of cool roofs in nonresidential Title 24 perspective requirements. Energy Policy, $\quad$ v. 33, $\quad$ p. 151-170, 2005. Disponível em: <"http://ville.montreal.qc.ca/pls/portal/docs/PAGE/ARROND_RPP_FR/MEDIA/DOCUMENTS/ENER GYPOLICY05\%20(TITLE\%2024).PDF"DOCUMENTS/ENERGYPOLICY05\%20(TITLE\%2024).PD F>. Acesso em> 28 out. 2016.

LEVINSON, R.; AKBARI, H. Potential benefits of cool roofs on commercial buildings: conserving energy, saving money and reducing emission of greenhouse gases and air pollutants. Energy Efficiency. vol, 3, n.1, p. 53109, mar. 2010.

LOVELAND, R. Thomas, et al. Development of a global land cover characteristics database and IFBP DISCover form $1 \mathrm{~km}$. Remote Sensing, vol. 21, n.6, p. 1303-1330, 2010. Disponível em: <http://glcf.umd.edu/library/guide/ijrs21_p1331.pdf>. Acesso em 17 out. 2016.

LOMBARDO, M.A. Ilhas de Calor nas Metrópoles: o exemplo de São Paulo. São Paulo; HUCITEC, 1985. 244 p.

MATOS, Laura B Rego de. A importância do setor de transportes na Emissão de Gases de Efeito Estufa. 2001. 179 f. Tese (Doutorado em Planejamento Energético) - COPPE - Universidade Federal do Rio de Janeiro, Rio de Janeiro.

MARCOTULLIO, P. et al. geography of global urban greenhouse gas emissions: an exploratory analysis. Climatic Change, v. 121, n. 4, p. 621-634, out. 2013. Disponível em:< http://link.springer.com/article/10.1007/s10584-013-0977-z> Acesso em 23 out. 2016.

MARTINS, R. Fernando et al. Mapeamento dos recursos de energia solar no Brasil utilizando modelo de transferência radiativa Brasil - SR. In: I CONGRESSO BRASILEIRO DE ENERGIA SOLAR, 1., 2007, Fortaleza. Anais eletrônicos, Fortaleza: ABENS, 2007. Disponível em: <http://ftp.cptec.inpe.br/labren/publ/eventos/CBENS2007_FernandoRMartins_etal.pdf>. Acesso em 12 out. 2016.

MARTINS, B. C. Ana. Respostas à mudança climática: cooperação internacional e os esforços de mitigação, adaptação e geoengenharia. 2009, 111 p. Faculdade de Ciências Econômicas. Universidade Federal do Rio Grande do Sul, Porto Alegre.

MARENGO, Jose A. Impactos de extremos relacionados com o tempo e o clima - Impactos sociais e econômicos. Boletim do Grupo de Pesquisa em Mudanças Climáticas. São Paulo, n. 8. P. 1-5, mai. 2009. Disponível em: < http://mudancasclimaticas.cptec.inpe.br/ rmclima/pdfs/newsletters/Boletim_No8_Port.pdf>.

MENON, Surabi, et al. Radiative forcing and temperature response to changes in urban albedos and associated $\mathrm{CO}_{2}$ offsets. Environmental Research Letter. vol. 5, n 1, p 1- 11, jan. 2010. Disponível em: <http://iopscience.iop.org/article/10.1088/1748-9326/5/1/014005/pdf>. Acesso em 24 ago. 2016.

MILLER, J. Harvey; SHAW, Shih-Lung. Geographic Information Systems for Transportation in the 21 st Century. Geography Compass, v.9, n. 4, p. 180 - 189, abr. 2015. Disponível em: <http://onlinelibrary.wiley.com/doi/10.1111/gec3.v9.4/issuetoc>. Acesso em 22 ago. 2016.

MINISTÉRIO DA CIÊNCIA, TECNOLOGIA E INOVAÇÃO (MCTi). Estimativas Anuais de Emissões de Gases de Efeito Estufa no Brasil (2º edição). Brasília, 2014. 168 p. 
MOSER, C. et al. Pro-poor adaptation to climate change in urban centers: case studies of vulnerability and resilience in Kenya and Nicaragua.. Washington, World Bank: Sustainable Development Network, 2010.

MYHE, Gunnar; MYHRE, Arne. Uncertainties in radiative forcing due to surfasse albedo changes caused by landuse changes. Journal of Climate, v. 50, p. 141-154, out. 2011. Disponível em:<https://www.academia.edu/20413563/Long-

term_hygrothermal_performance_of_white_and_black_roofs_in_North_American_climates?auto=downl oad>/. Acesso em 21 ago. 2016.

NAKARUMA, Juliana. Pavimentação asfáltica: Os tipos de revestimentos, o maquinário necessário e os cuidados na contratação, projeto e execução. Infraestrutura Urbana, dez. 2011. Disponível em: < http://infraestruturaurbana.pini.com.br/solucoes-tecnicas/16/pavimentacao-asfaltica-os-tipos-derevestimentos-o-maquinario-necessario-260588-1.aspx> . Acesso em 17 out. 2016.

NOBRE, A. Carlos et al. Vulnerabilidades das Megacidades Brasileiras às Mudanças Climáticas: Região Metropolitana de São Paulo. São José dos Campos: INPE, 2010.

NOBRE, Carlos A.; REID, Julia; VEIGA, Ana Paula S. Fundamentos Científicos das Mudanças Climática. São José dos Campos: Rede Clima/INPE, 2012.

OBSERVATÓRIO DO CLIMA Análise da evolução das emissões de GEE no Brasil (1990-2012). São Paulo, 2014. 21p.

OBSERVATÓRIO DO CLIMA. Análise das Emissões de GEE Brasil (1970-2014) e suas implicações para políticas públicas e a contribuição brasileira pra o Acordo de Paris. 2016, 44 p.

OKE, T. R. Boundary Layer Climates. 2 ed., Inglaterra: Taylor \& Francis Group, 1987.

OLESON, K. W.; BONAN, G. B.; FEDDEMA, J. E. Effects of White roofs on urban temperature in a global climate model.Geophysical Research Letters, v. 37, n.3, p. 1-7, fev. 2010. Disponível em :< http://onlinelibrary.wiley.com/doi/10.1029/2009GL042194/pdf> . Acesso em 26 jul. 2016.

ORGANIZAÇÃO DAS NAÇÕES UNIDAS (ONU). World Urbanization Prospects-The 2014 Revision. Nova Iorque, 2014. $32 \mathrm{p}$.

PBMC. Mitigação das mudanças climáticas. Contribuição do Grupo de Trabalho 3 do Painel Brasileiro de Mudanças Climáticas ao Primeiro Relatório da Avaliação Nacional sobre Mudanças Climáticas. Rio de Janeiro, 2014a. 463p.

PBMC. Base científica das mudanças climáticas. Contribuição do Grupo de Trabalho 1 do Painel Brasileiro de Mudanças Climáticas ao Primeiro Relatório da Avaliação Nacional sobre Mudanças Climáticas. Rio de Janeiro, 2014b. 464p.

PBMC. Impactos, vulnerabilidades e adaptação às mudanças climáticas. Contribuição do Grupo de Trabalho 2 do Painel Brasileiro de Mudanças Climáticas ao Primeiro Relatório da Avaliação Nacional sobre Mudanças Climáticas. Rio de Janeiro, 2014c. 414p.

PEREIRA, André; MAY, Peter. Economia do aquecimento global. In: May, Peter; Lustosa, Maria Cecília; Vinha, Valéria da (orgs.), Economia do meio ambiente: teoria e prática. Rio de Janeiro: Elsevier, 2003.

PEREIRA, B. Enio; et al. Atlas Brasileiro de Energia Solar. São José dos Campos, SP: INPE, 2006.

PORTAL BRASIL. Painel Intergovernamental sobre Mudança do Clima (IPCC). 2010. Disponível em: < http://www.brasil.gov.br/meio-ambiente/2010/11/painel-intergovernamental-sobre-mudanca-do-climaipcc>

RECIFE. Prefeitura da Cidade de Recife. 1 Inventário de Emissões de Gases de Efeito Estufa para a cidade do Recife. Recife, 2014. 46 p.

RIBEIRO, Kahn S. et al. Transportation and Climate Change.Tradução de Carolyn Rio de Janeiro: COPPE/UFRJ, 2003. 
RIBEIRO, Costa W. Impactos das Mudanças Climáticas em cidades no Brasil. Parcerias Estratégicas, n 27, p. 297-391, dez. 2008. Disponível em: < http://laboratorios.cetesb.sp.gov.br/wpcontent/uploads/sites/28/2014/05/ribeiro_impactos.pdf>. Acesso em 17 set. 2016.

RIO DE JANEIRO (Cidade). Prefeitura do Rio de Janeiro. Secretaia de Meio Ambiente. Mudanças Climáticas e Desenvolvimento Sustentável. 2015. Disponível em: <http://www.rio.rj.gov.br/web/smac/mudancasclimaticas2>. Acesso em 17 jul. 2016.

RIO DE JANEIRO (Cidade). Prefeitura do Rio de Janeiro. Rio Resiliente - Diagnóstico e Áreas de Foco. Rio de Janeiro, 2015. $55 \mathrm{p}$

RIO DE JANEIRO (Estado). Secretaria de Estado de Transportes. Plano Diretor de Transporte da Região Metropolitana do Rio de Janeiro - Relatório 1: Revisão das Informações Disponíveis. Rio de Janeiro, 2015 b. 126 p. Disponível em: <http://download.rj.gov.br/documentos/10112/2860844/DLFE88174.pdf/Relatorio1RevisaodasInformacoesDisponiveis.pdf>. Acesso em 27 ago 2016.

ROGELJ, J. et al. Paris Agreement climate proposals need a boost to keep warming below 2C. Nature, v. 534, n. 534, p. 631- 639, jul. 2016, Disponível em:< doi: 10.1038/nature18307> Acesso em 29 out. 2016.

ROZENZWEIG, C. et al. Attributing physical and biological impacts to anthropogenic climate change. Nature, v. 45, n. 453, p. 353-357, mar. 2008. Disponível em: <http://www.nature.com/nature/journal/v453/n7193/pdf/nature06937.pdf>. Acesso em 17 set. 2016.

SABER, Hamed, H. et al. Long-term hygrothermal performance of white and black roofs in North American climates. Building and Environment, vol. 50, p. 136-177, 2011. Disponível em: $<$ https://www.researchgate.net/publication/257171772_Long-

term_hygrothermal_performance_of_white_and_black_roofs_in_North_American_climates"term_hygrot hermal_performance_of_white_and_black_roofs_in_North_American_climates>. Acesso em 30 out. 2016.

SANTOS, Souza A. A importância do Setor de Transporte para o Aumento de Resiliência das Cidades Frente à Mudança Climática: Uma proposta de Plano de Ação para a cidade do Rio de Janeiro. 2014. 152 p., Tese (Doutorado em Engenharia de Transportes) - COPPE, Universidade Federal do Rio de Janeiro, Rio de Janeiro.

SÃO PAULO (Cidade). Prefeitura do Município de São Paulo. Secretaria do Verde e Meio Ambiente. Relatório Técnico - Produto 7B: Atualização do Inventário de Emissões e Remoções Antrópicas de Gases de Efeito Estufa do Município de São Paulo dos anos de 2010 e 2011. São Paulo, 2012. 30 p.

SCHENEIDER, S. H. Geoegineering: Could - or should - we do it?. Climatic Change, v. 33, n. 3, p. 291-302, jul. 1996. Disponível em: < http://link.springer.com/article/10.1007/BF00142577>. Acesso em 04 nov. 20016.

SILVA, B. Bernardo; LOPES, M. Gláucia, AZEVEDO, V. Pedro. Balanço de radiação em áreas irrigadas utilizando imagens LANDSAT 5- TM. Revista Brasileira de Meteorologia, v. 20, n. 2, p. 243-252, fev. 2005. Disponível em:<http://www.dca.ufcg.edu.br/DCA_download/ISR/UFPE/56-2004_BBarbosaaceito.pdf> . Acessado em 2 out. 2016.

SILVA, Muniz da R. Caminhos para a sustentabilidade: Alterações climáticas e sociedades em transição. Boletim da Geografia, v., 31, n., 2, p. 5-18, ago. 2013. Disponível em: < http://dx.doi.org/10.4025/bolgeogr.v31i2.18690>. Acesso em 19 set. 2016.

SOLECKI, W.D. et al. Mitigation of the heat island effect in urban New Jersey. Environmental Hazards, v. 6, p. 39-49, dez. 2005. Disponível em:< http://pubs.giss.nasa.gov/docs/2005/2005_Solecki_so04000r.pdf >. Acesso em 8 set. 2016.

STATTERHWAITE, David. The Contribution of Cities to Global Warming and their Potential Contributions to Solutions. Environment and Urbanization, v. 1, n. 1, p. 1-12, mar. 2010. Disponível: < http://eua.sagepub.com/content/1/1/1.short> Acesso em 3 out. 2016. 
SYNNEFA, Afroditi et al. On the Use of Cool Materials as a Heat Island Mitigation Strategy. Journal of applied Meteorology and Climatology, vol. 41, p. 2846-2856, mar. 2008. Disponível em: <http://journals.ametsoc.org/doi/pdf/10.1175/2008JAMC1830.1>. Acesso em 19 out. 2016.

TIBA, Chigueru, et al. Atlas Solarimétrico do Brasil. Recife, PE: Ed. Universitária da UFPE, 2000. 111p.

TOLENTINO, Lucas. Aprovado na Câmara, texto do Acordo de Paris segue para o Senado. EcoD. Disponível em: $<\quad$ http://www.ecodesenvolvimento.org/posts/2016/posts/julho/aprovado-na-camara-texto-do-acordo-deparis-segue/>. Acesso em 28 ago. 2016.

UN-HABITAT. Cities and climate change: global report on human settlements 2011: Cities and Climate Change. London, 2011. $300 \mathrm{p}$.

UN-HABITAT. Streets as public spaces and drivers of urban prosperity. Nairobi, 2013. $168 \mathrm{p}$.

UN-HABITAT, 2015 a. Global Activities Report 2015. Increasing Synergy for greater National Ownership. Nairobi, 2015. 105 p.

UN-HABITAT, 2015 b. Activities of the United Nations Human Settlements Programme. Nairobi, 2015. 13 p.

CONCELLOS, A. de Eduardo. Transporte e meio ambiente: conceitos e informações para análise de impactos. São Paulo, 2006.

WINTON, Michael. Surface albedo feedback estimates for the AR4 climate models. Journal of Climate, vol. 19, p. 359-365, fev. 2006. Disponível em: <https://www.gfdl.noaa.gov/bibliography/related_files/mw0602.pdf>. Acesso em 27 jul. 2016

WHILE, Aidan; WHITEHEAD, Mark. Cities, Urbanisation and Climate Change. Urban Studies, vol, 50 n. 7, p. 1325-1331, mai, 2013. Disponível em:<http://usj.sagepub.com/content/50/7/1325.extract >. Acesso em 12 out. 2016

WORLD BUSINESS COUNCIL FOR SUSTAINABLE DEVELOPMENT (WBCD). The Sustainable Mobility Project Full Report. Geneva, 2004. 180 p.

$\mathrm{XU}$, T. et al. Quantifying the direct benefits of cool roofs in an urban setting: reduced cooling energy use and lowered greenhouse gas emissions. Building and Environment, vol. 48, n. 1, p. 1-6, fev. 2012. Disponível em:

<https://www.researchgate.net/publication/230887933_Quantifying_the_direct_benefits_of_cool_roofs_i n_an_urban_setting_Reduced_cooling_energy_use_and_lowered_greenhouse_gas_emissions > Acesso em 25 out. 2016. 